\title{
Las ciudades celtibéricas de la Meseta Oriental
}

\author{
The Celtiberian towns of the Eastern Meseta
}

\author{
Alfredo Jimeno Martínez \\ Departamento de Prehistoria. Universidad Complutense, 28040-Madrid \\ aljimen@ghis.ucm.es
}

Recibido: 02-02-2011

Aceptado: 20-05-2011

\section{RESUMEN}

Se aborda, inicialmente, el territorio objeto de estudio, ocupado por los celtíberos, atendiendo a sus características ambientales y económicas, con especial incidencia en la zona oriental de la Meseta, donde se sitúa la Celtiberia Ulterior, vinculada en gran medida al Alto Duero. En este marco de referencia, la documentación arqueológica permite analizar los antecedentes e inicios del urbanismo celtibérico, desarrollado con anterioridad a las primeras noticias que, al ritmo de la conquista romana, aportan los textos greco-latinos sobre ciudades celtibéricas. El conjunto de la documentación arqueológica y textual proporciona un mejor conocimiento de la ordenación del poblamiento celtibérico, teniendo como referencia la ciudad-estado, atendiendo a su territorio, urbanismo, defensas, arquitectura doméstica, consideraciones demográficas, formas de gobierno y su reflejo en el ritual funerario. Finalmente, se plantean las transformaciones sufridas por el poblamiento celtibérico y el gobierno de la ciudad tras la conquista romana.

Palabras Clave: Poblamiento celtibérico. Ciudades-estado. Edad del Hierro. Meseta Oriental.

\begin{abstract}
The geographical territory of the Celtiberians is analyzed according to their environmental and economic characteristics, with special emphasis on the eastern plateau of Castile where the Celtiberia Ulterior was located in the High Douro basin. In this framework, the archaeological evidence allows to analyze the background and beginnings of the Celtiberian urbanism, which started before the first information available from the Greco-Roman throughout the Roman conquest of the area. The bulk of archaeological and textual documentation provides a better understanding of the Celtiberian settlement organization, including the city-state as a key reference, the territory, urbanism, defenses, domestic architecture, demography, and the forms of government and their reflection in the funerary rituals. Finally, the paper analyzes the transformations that took place in this polity after the Roman conquest.
\end{abstract}

KeY worDs: Celtiberian settlement. City-states. Iron Age. Eastern Meseta.

Sumario 1. Introducción. 2. Territorio y grupos humanos. 3. Antecedentes del urbanismo celtibérico. 4. Inicio de las ciudades en elAlto Duero. 5. Las primeras noticias sobre ciudades. 6. Las ciudades y sus problemas de localización. 7. Ordenación del poblamiento: ciudades-estado y territorio. 8. Consideraciones demográficas. 9. Entidades políticas y formas de gobierno. 10. Reflejo de la organización urbana en el ritual funerario. 11. Transformación del territorio conquistado. 12. El nuevo orden romano tras las Guerras Sertorianas. 


\section{Introducción}

Las ciudades celtibéricas empiezan a ser conocidas al ritmo de la conquista romana, por la información que de ella transmiten los textos romanos, lo que llevó a vincular el origen del urbanismo celtibérico con este proceso, que tuvo lugar a partir de los inicios del siglo II a.C. Este planteamiento implicaba negar la ciudad al desarrollo cultural indígena (Burillo 1998) o adjudicarle un discreto papel, asumiendo que antes de la llegada de los romanos solamente existiría un incipiente urbanismo sobre el que Roma constituyó de manera ficticia ciudades apoyadas en las organizaciones indígenas (Salinas 1988).

La bibliografía reciente, atendiendo a la información arqueológica disponible y a la interpretación de las fuentes escritas -al final de la primera guerra celtibérica el tratado que Tiberio Sempronio Graco (179 a. C.) firma con las ciudades celtibéricas obligaba a los indígenas a no construir nuevas ciudades- permite vincular, sin ninguna duda, el desarrollo urbano a la cultura celtibérica, que puede presentar desfases entre el valle del Ebro y el Duero, a lo largo de los siglos V-IV y III a.C. Por otro lado, resulta difícil diferenciar aquellos pequeños asentamientos de otros similares, que llegarán a ser ciudades, ya que será la dinámica a lo largo del tiempo la que determinará su diferenciación y complejidad. Sirva como ejemplo el proceso del origen del urbanismo medieval, mejor conocido, que conllevó una gestación de al menos dos siglos hasta que determinadas aldeas alcanzaron el nombre de ciudades.

Lo que se conoce como la Celtiberia Histórica se extendería desde la margen derecha del Ebro medio para abarcar las cabeceras de Duero Tajo y Jalón, implicando actualmente a cinco comunidades autónomas: Aragón (parte de las provincias de Teruel y Zaragoza), Castilla-La Mancha (parte de la provincia de Guadalajara y Cuenca), Castilla y León (toda la provincia de Soria, una parte de la provincia de Burgos y una más pequeña de Segovia), así como La Rioja y Navarra (la zona situada a la margen derecha del Ebro). En este capítulo, aunque necesariamente tengamos que hacer referencias al contexto general de la Celtiberia, trataremos de ajustarnos, en la medida de lo posible, al marco geográfico establecido para este número de Complutum, que se corresponde básicamente con la zona del Alto Duero, identificada por Schulten (1945: 18) como la Celtiberia Ulterior.

\section{Territorio y grupos humanos}

\subsection{La Celtiberia y su marco ambiental}

Aunque existe discordancia entre los historiadores de la antigüedad, se puede deducir de sus noticias, referidas a los siglos II y I a. C, que se da el nombre de Celtiberia al territorio situado en el reborde montañoso donde se encajan las cordilleras Ibérica y Central y sus zonas aledañas, a caballo en las divisorias de las cuencas del Tajo, Ebro y Duero, es decir, la zona oriental de la Meseta Norte y el lado derecho de la cuenca media del Ebro (Fig. 1).

Estos historiadores describen la zona celtibérica como áspera, montañosa y por lo general estéril, condicionada por la dureza del clima, con fuertes heladas y abundantes nevadas, y azotada por el terrible viento norte, denominado cizicus, el cierzo (Estrabón, 4,1213; App, Iber., 47 y 78; Marcial, 1,49,22). No obstante, se diferencia la Celtiberia Citerior, de mayores posibilidades agrícolas y riqueza básica, más abierta a influencias exteriores provenientes fundamentalmente del Mediterráneo ibérico, y la Celtiberia Ulterior, circunscrita al Alto Duero, con predominio ganadero y más marginada de los focos económicos y caminos dominantes, vinculados con el Mediterráneo.

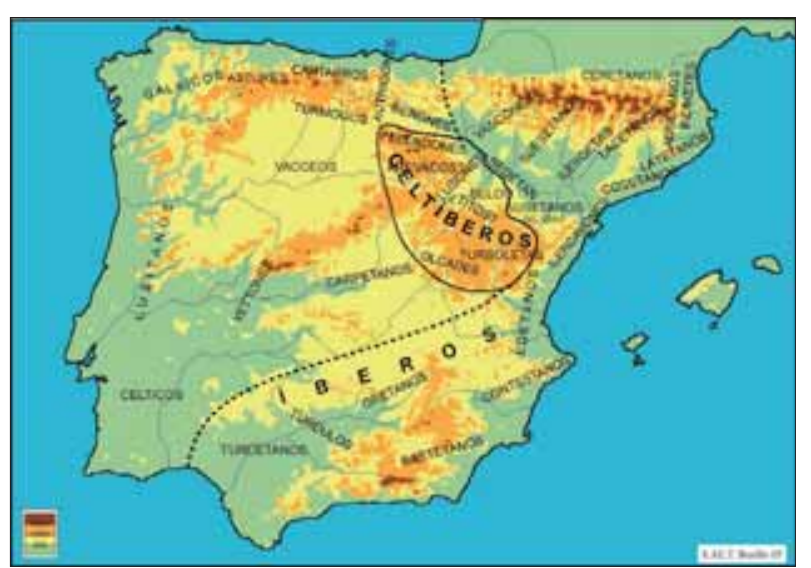

Figura 1.- Marco de la Celtiberia. 
Se aprovechaban los ricos pastos, idóneos para la cría de ovejas y cabras, como principal fuente de riqueza. Con su lana se realizaban las prendas de vestir, entre las que destaca el sagum (de una pieza de color pardo o negro), para defenderse de los rigores climáticos, que fue muy apreciado por los romanos, como se deduce de que entre los impuestos de guerra exigidos a las ciudades celtíbéricas aparezcan siempre miles de estas prendas (en el 141 a. C., a las ciudades de Numancia y de Termes se les exigía la entrega de 9.000). También, eran abundantes los asnos, mulos y caballos; éstos tenían fama de rápidos, lo que llevó a los romanos a su utilización en detrimento de los itálicos. Por otro lado, los bosques proporcionaban caza abundante como ciervo, jabalí, liebre, conejo, oso y lobo, que están bien documentados entre los huesos hallados en los yacimientos, y que prueban la existencia de un bosque mixto.

La ganadería se completaba con la agricultura, al parecer poco extendida, a mayor altura, en donde el cereal a veces escaseaba, a diferencia de la zona central del río Duero, habitada por los vacceos, en donde el grano era abundante. Esto ocasionó, a veces, a los romanos la falta de trigo, por lo que tuvieron que contentarse, según los textos, con la caza de liebres y ciervos. Lo que coincide con el comentario de Apiano, que indica que "mercaderes remontaban el río en pequeños esquifes (...) con ayuda de velas, para transportar vino y cereal". Los análisis realizados en diferentes yacimientos han proporcionado restos de trigo, cebada (vestida y desnuda), trigo (común, escanda y espri1la), mijo, centeno y avena; entre las leguminosas: haba, almortas, yero, veza y en el valle del Ebro la vid (Cubero 2005: 307). Un complemento importante en la dieta alimenticia era la recolección de frutos secos, sobre todo bellota de ocho molinos que se han analizado en Numancia, cinco habían molido bellotas y los otros tres trigo y cebada, uno de ellos trigo malteado (Checa et al. 1999: 63), que pudo haber servido a través de su fermentación para fabricar la caelia o cerveza, que según Orosio $(5,7,13)$ era de sabor áspero y daba un calor embriagador.

Una fuente o recurso destacado por los autores clásicos está en relación con la riqueza férrica del Moncayo, ya que Posidonio, Marcial y Justino alaban la calidad de los aceros templados en las aguas de los ríos celtibéricos. Sus especiales características llevaron al ejército romano a adoptar la espada peninsular, el gladius hispaniensis, caracterizada por tener una punta excelente y un duro golpe con ambos filos.

\subsection{Pueblos y ciudades}

La sociedad celtibérica, a lo largo de los siglos (VI-I a. C.), fue adoptando una estructura más jerarquizada. Inicialmente, se caracterizó por comunidades relacionadas por estrechos lazos de parentesco, con un uso colectivo de la tierra o territorio, en que se asentaban, y sus miembros se regían por un conjunto de deberes, derechos y prácticas religiosas, que obligaban a todos. Esta forma de organización suprafamiliar, quedaba estructurada en gentilitates (clanes), divisiones de una organización superior, la gens o tribu, que a su vez podían agruparse o confederarse constituyendo lo que se conoce históricamente por populi, como los celtíberos.

Las fuentes literarias muestran una territorialidad y una composición étnica cambiante y difícil de definir, ya que a la complejidad para la identificación global de su territorio se unen los desacuerdos a la hora de concretar las diferentes etnias celtibéricas (Fig. 2). Según Estrabón (III, 4,13), los Celtíberos se dividían en cuatro partes: "los más poderosos" situados el Este y al Sur; "los de la parte posterior", que lindan con los Carpetanos y las fuentes del

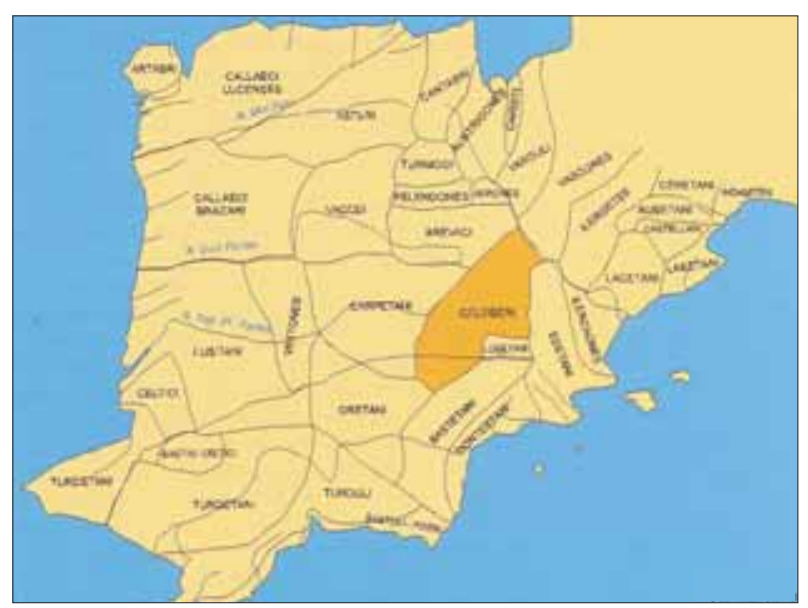

Figura 2.- Los celtíberos a partir de Ptolomeo. 
Tajo, y cuya ciudad más celebre es Numancia; los lusones, situados hacia el Este y llegando también a las fuentes del Tajo; y los arévacos, a los que se atribuyen las ciudades de Segeda y Pallantia.

No está claro qué otros grupos acompañaban arevacos y Lusones. Por Polibio (XXXV, 2) y Apiano (Iber., 48-66) se sabe que los belos, a los que pertenecía la ciudad de Segeda, y los titos, citados como vecinos de aquéllos, eran pueblos celtibéricos. También, son referidos por Plinio (III, 26) los pelendones, como pertenecientes a este grupo, les atribuye la ciudad de Numancia. Pero Estrabón (III,4,19), a continuación del texto comentado más arriba, indica: "Dicen algunos que este país (La Celtiberia) está dividido en cuatro partes, como hemos dicho, mientras que otros sostienen que son cinco las partes". A partir de este pasaje, Schulten (1952: 263) consideró que ese quinto pueblo serían los vacceos; pero estudios recientes han puesto en evidencia las diferencias de poblamiento y territorialidad de este grupo, que ocupó el valle medio del Duero, con sus vecinos arévacos. Finalmente, Plinio (III, 26), que escribe sobre la Hispania Citerior, tras las reformas de Augusto, se refiere como celtíberos únicamente a arevacos y pelendones, introduciendo dos referencias sobre límites de la Celtiberia, una en relación con la ciudad de Clunia (Peñalba de Castro, Burgos), como Celtiberia finis, y otra a los caput Celtiberiae Segobrigenses (en la región de Segobriga, en Saelices, Cuenca)

Plinio (III, 26 y IV, 112) adscribe a los pelendones al Convento Cluniense con cuatro populi "de los que fueron ilustres los numantinos" (Capalvo 1996: 67). Entre ellos nacía el Duero que, "pasando junto a Numantia, corre luego entre los arevacos" (Taracena 1929 y 1954: 200-206) situó a los pelendones en la Serranía Norte de Soria, relacionándolos con la denominada Cultura Castreña Soriana (siglos VI-IV a.C.). La cita de los pelendones por Plinio corresponde a un momento avanzado (siglo I d. C.). No existen noticias anteriores, solamente se ha interpretado, como una alusión velada a esta tribu, un pasaje de Apiano (Iber., 77) en el que indica que arévacos y numantinos son gentes emparentadas pero distintas (según algunos autores dice numantinos por pelendones). Las ciudades atribuidas a los pelendones plantean bas- tante confusión a la hora de establecer sus límites y relación con los arévacos, ya que ciudades como Numantia, Savia, Augustóbriga o Nova Augusta, son consideradas por otros autores como arevacas: Numantia y Savia en Estrabon y Ptolomeo, Nova Augusta en Plinio y Ptolomeo y acaso Contrebia Leukade y Aregrada en Livio.

Para la localización de los arévacos se tienen las noticias aportadas por Plinio (III, 4, 11), que relaciona su nombre con el río Areva, $\mathrm{y}$, sobre todo, por Ptolomeo, que da la relación y situación de sus ciudades. Taracena (1954: 199-200), tomando esta información detallada, concreta los límites de los arévacos, por el Norte, con el de los pelendones; por el Este, que seguiría la vertiente occidental del Moncayo; por el Sur desbordaría la Meseta para alcanzar Sigüenza y luego nuevamente recobraría la divisoria de los montes Carpetanos por Sierra de Cabras, Sierra Pela y hasta Sierra de Ayllón. Finalmente, por el Oeste subiría desde allí hasta Clunia (Celtiberiae finis, según Plinio, III, 27), por el limite actual de Soria y Segovia, para unir nuevamente con la Idubeda (Cordillera Ibérica) al Oeste de la Demanda (Taracena 1954: 199200). El límite de los arevacos hacia el Sureste con los belos lo situó por el puerto de Alentisque (Soria), algo más al Norte del Jalón, coincidiendo con la propuesta de Schulten (1945: 24).

Los Lusones, como se ha indicado en el texto de Estrabón (II, 4, 13), se situaban al Este de la Celtiberia, llegando hasta las fuentes del Tajo, y según Apiano (Iber. 79), habitaban cerca del Ebro y eran vecinos de los numantinos. La ubicación de los belos ha sido precisada, por Burillo (1986: 543), en la zona del Jalón Medio y Bajo Jiloca, desplazándolos del Alto Jalón, e, incluso, reconoce que las referencias a los titos no permite, por el momento, precisar su territorio (Burillo 1986: 543). Se ha situado este pueblo entre las sierras de Solorio y Ministra e, incluso, tratando de superar la falta de datos de las fuentes escritas, se proponen referencias arqueológicas -ausencia de armas en los ajuares de las necrópolis de Aguilar de Anguita, Luzaga y Riba de Saelices, se explicarían por la clientela de éstos con los belos- para identificar el territorio de los titos (Ruiz-Gálvez 1985-1986: 98-99) (Fig. 3).

Es probable que todas estas aparentes contradicciones entre los diferentes autores, a la hora de atribuir pueblos a los celtíberos o las mismas 


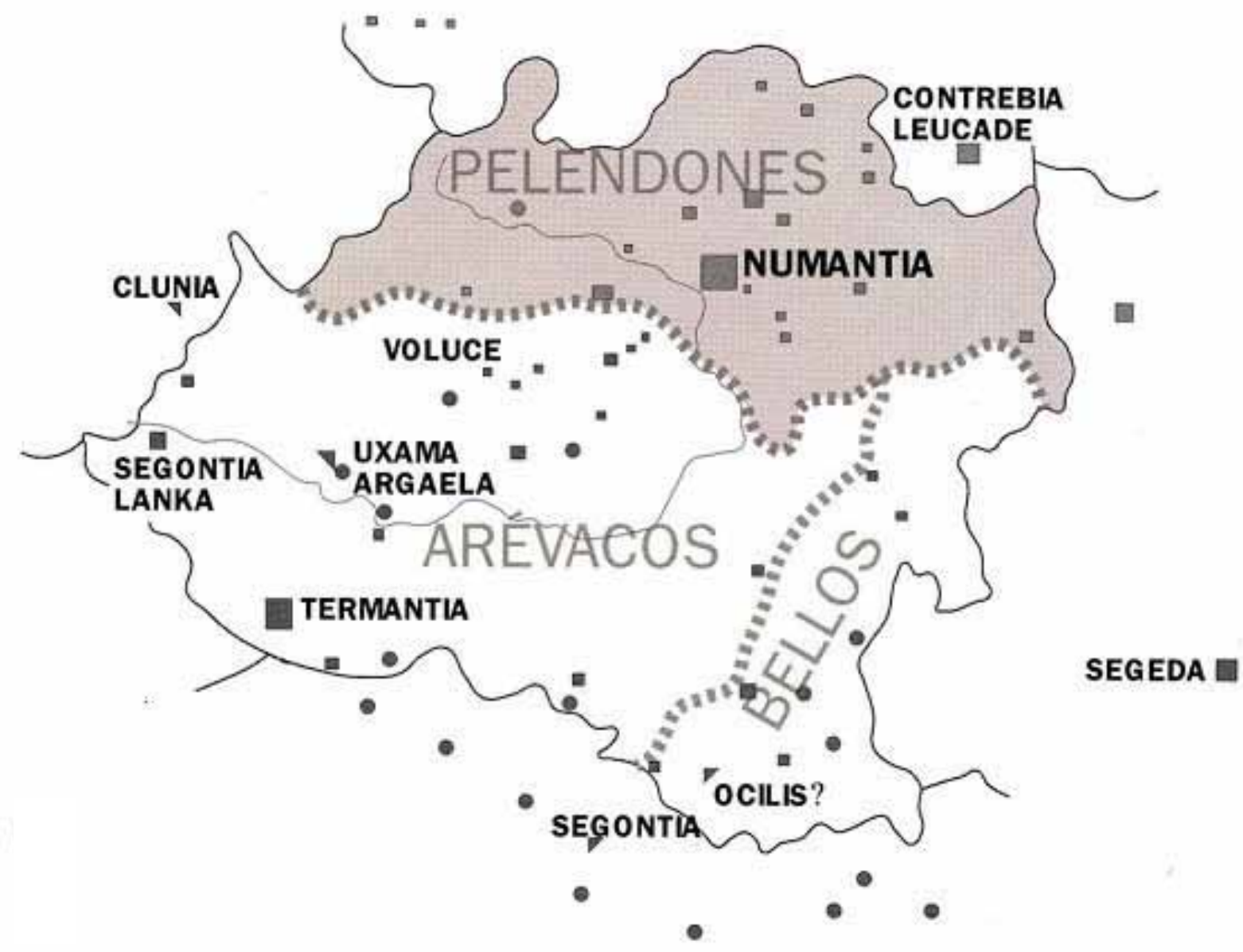

Figura 3.- Pueblos y ciudades celtibéricas en la zona del Alto Duero (Taracena 1941).

ciudades a diferentes grupos, puedan estar reflejando los cambios y los desplazamientos de "fronteras", sufridas por estos pueblos a lo largo del amplio marco cronológico en el que los distintos autores se refieren a esta zona, sujeta a importantes cambios como consecuencia de las diferentes guerras y los cambios administrativos, que debieron afectar sustancialmente a este territorio celtibérico. Así, la atribución de la ciudad de Numancia por Apiano (Iber. 45 y 46) a los arévacos y pelendones (Plinio, III, 26) fue interpretada por Schulten (1945: 25), admitiendo que los pelendones pudieron haber formado parte de los arévacos. Bosch (1932: 553) lo explicó como consecuencia de la expansión de los arévacos hacia el Norte, que arrebatarían a los pelendones parte de su límite sur, que les sería devuelto posteriormente por los romanos, después de las Guerras Sertorianas (83-72 a. C.), al practicar estos una política de reintegración de fronteras.
Aunque no haya en los textos clásicos bases suficientes (el único que se refiere a una Celtiberia Ulterior es Livio) para diferenciar la Celtiberia entre Citerior y Ulterior (Capalvo 1994: 63 y 1996: 107); la historiografía, desde los trabajos de Schulten (1914: 119 y 1945: 28) ha venido aceptando esta división circunscrita, en lo que hace referencia a la Citerior, a la zona media del Ebro, relacionada con belos, titos y lusones, y a la Ulterior, con la zona del Alto Duero, ocupada por pelendones y arévacos.

\section{Antecedentes del urbanismo celtibérico}

El impacto orientalizante del mundo mediterráneo se acusará en un momento temprano en la zona del Bajo Ebro (finales del siglo VII y primera mitad del s. VI a.C.), donde los contactos comerciales muestran la presencia de ánforas fenicias y elementos de vajilla, vinculados 
con el consumo ritual del vino en los simposia. (Graells et al. 2009: 351). En un corto espacio de tiempo estos aportes mediterráneos alcanzarán el Ebro Medio, donde la necrópolis de Castejón, Navarra, aporta tumbas diferenciadas socialmente, con elementos también vinculados con el consumo del vino y escarabeos egipcios (Faro y Unzu 2006).

Se observa cómo a partir de este momento, la influencia iberizadora, espoleada por las aportaciones colonizadoras de fenicios y griegos, establecerá contactos comerciales con los pueblos indígenas de las zonas del interior, lo que se acusa en la incorporación de nuevos y más variados elementos de cultura material de procedencia diversa (Arenas 1999; Cerdeño et al. 1999: 267). Así, en la vertiente sur del Sistema Central se acusa, ya desde el s. VI a.C., un flujo de materiales suntuarios, relacionados con vajillas, como la presencia de urnas de cerámica con orejetas, relacionadas con un sistema de cierre hermético, que podían transportar productos alimenticios de elaboración mediterránea y que, dada su peculiaridad, debieron de tener un consumo restringido. También se han observado ciertas concomitancias en los

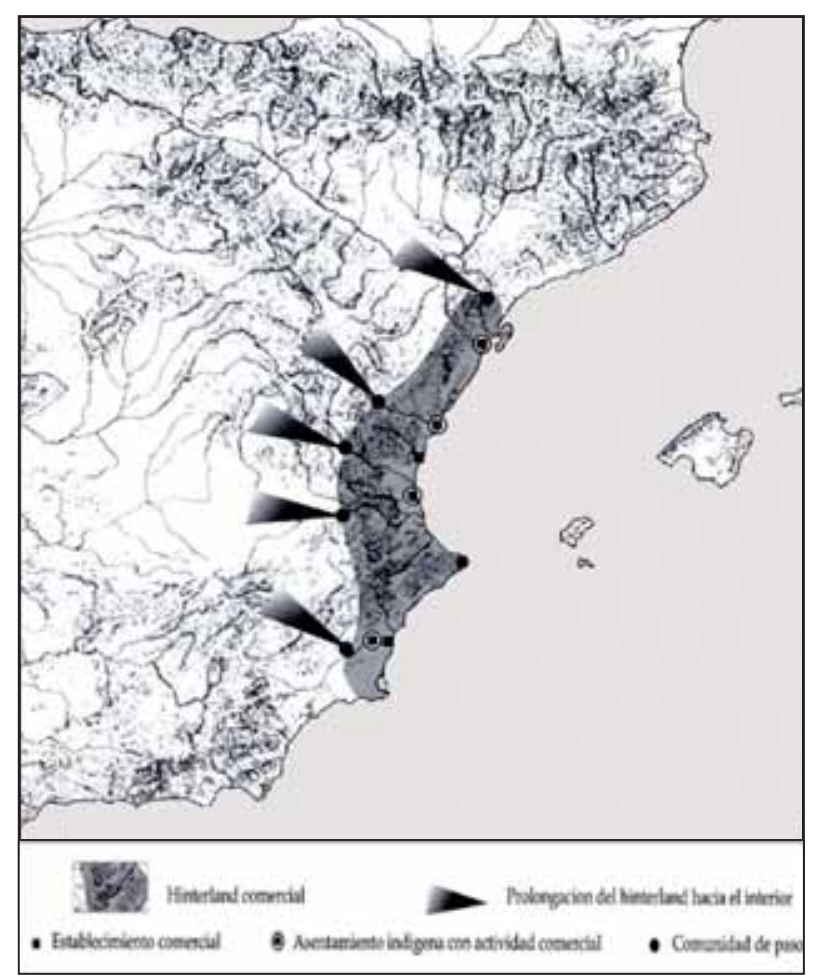

Figura 4.-Modelo de implantación territorial que canalizaría los contactos entre el interior y la zona mediterránea (Arenas 1999). rituales funerarios con sacrificios animales y cuchillos de empuñadura maciza de tipo mediterráneo, que estarían transmitiendo connotaciones de carácter ritual (Arenas 2005: 395).

A su vez, las tierras del Alto Duero y sus rebordes montañosos, de los sistemas Ibérico y Central, parece que permanecieron un tanto ajenas a ese discurrir comercial y cultural por el valle del Ebro. La etapa inicial del mundo celtibérico (s. VI-V a.C.) se caracteriza por la dualidad de poblamiento: asentamientos de tipo castreño con fuertes sistemas defensivos en los rebordes montañosos, sobre todo del Sistema Ibérico, de los que desconocemos su ritual funerario (Taracena 1929; Romero Carnicero 1991); en los valles y zonas llanas, pequeños asentamientos, situados en cerros de fácil defensa, asociados a necrópolis de incineración, con ricos ajuares metálicos, entre los que destacan, en un momento algo más avanzado que en el Ebro (finales del siglo VI y, sobre todo, en el V a. C.), panoplias armamentísticas de hierro y objetos de adorno de bronce, que muestran contactos con el mundo ibérico, del sureste y Alto Guadalquivir, como lo prueba el hallazgo de umbos de escudos circulares (caetra), cascos y pectorales, en tumbas de las necrópolis de Aguilar de Anguita (Guadalajara), Alpanseque, Almaluez y Carratiermes (Soria) (Lorrio 1997: 147; Quesada 1997: 571). A estos aportes se unirán, algo más tarde, los relacionados con el mundo europeo de La Tène, a partir de mediados del siglo IV a.C., que alcanzarán el occidente y el sureste meseteño. (Lenerz de Wilde 1986; Martín Valls y Esparza 1992; Álvarez-Sanchís 1999). Todo ello, estaría reflejando una organización con tendencia a la desigualdad social, ya que algunos miembros, disponían de capacidad adquisitiva para dotarse de elementos prestigiosos, vinculados con el armamento, procedentes de centros de producción foráneos, lo que reforzaría la adquisición de poder, basado en el "acceso diferencial o al control de recursos limitados" (Ruiz Zapatero 1984: 83-84).

No deja de llamar la atención que estas necrópolis antiguas, a las que hay que añadir las de Sigüenza, Valdenovillos (Alcolea de las Peñas) y Atienza, circunscritas a la zona del Alto Tajo-Alto Jalón, a caballo entre las provincias de Guadalajara y Soria, estén ubicadas 
en relación con ricas salinas (Fig. 4), algunas explotadas históricamente hasta un momento reciente y que pudo ser la base de los excedentes para la adquisición de la riqueza acumulada en las tumbas (Arenas 1999). Se observa una incidencia de estas necrópolis hacia la llanada meseteña, como La Dehesa de Ayllón y Los Azafranales de Coca, fines del s. VI e inicios del V a.C. (Blanco 2005: 401). La comercialización de la sal, además de servir para el alimento animal y la siderurgia, permitía sobre todo la conservación de productos básicos para la alimentación humana, como la carne y el pescado, lo que mejoraría las condiciones de vida al prolongar la duración de los alimentos perecederos, consiguiendo así una mayor seguridad y rentabilidad de las actividades agrarias, pudiendo generar excedentes para los intercambios, como ya fue planteado para la zona de Hallstatt (Wells 1988: 78-79) (Fig. 5).
El hecho es que, a lo largo del siglo IV a. C., un número de castros, que basaban una parte significativa de su riqueza en la ganadería, se deshabitan y, por el contrario, otros, los menos, muestran en su roquedo una resistencia mayor, incluso se dejan "contaminar" con la presencia de cerámicas torneadas oxidantes, decoradas con anchas franjas de color vinoso, en diferentes yacimientos, de clara influencia ibérica mediterránea (Jimeno 2005). De esta manera el "paisaje" doméstico se enriquece, ya que las cerámicas a mano, de tonos oscuros e irregulares, se van a intercalar tecnológica, cromática y formalmente con la decoración pintada, anchura de líneas $\mathrm{y}$ tono vinoso de sus pinturas, sentando la base para las excelentes manufacturas posteriores de las cerámicas celtibéricas (Jimeno 2005: 59).

La demanda de estos nuevos productos, a lo largo de los siglos IV y III a.C., están relacionados con una serie de cambios importantes

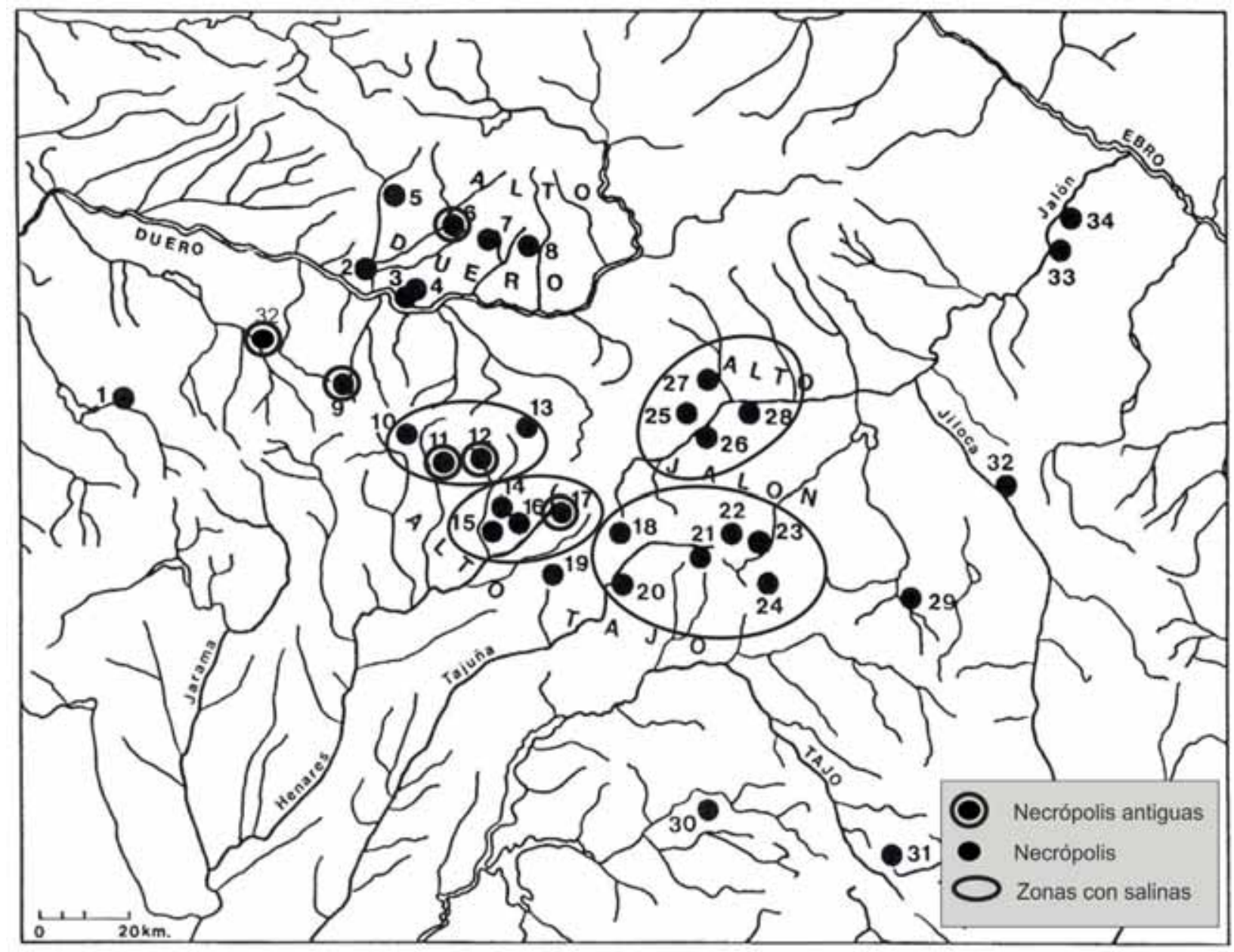

Figura 5.- Las necrópolis celtibéricas y la relación de las más antiguas con las zonas de salinas. 
que se plasman en el paisaje en un aumento de poblados, asociados a necrópolis amplias y bien diferenciadas, de las que se conocen unas treinta en las zonas del Alto Tajo, Alto Jalón y Alto Duero, destacando la riqueza y diferenciación de sus ajuares; claro indicio, a su vez, de un significativo aumento demográfico. Así, la importancia que originariamente había tenido la zona del Alto Tajo-Alto Jalón, en el número de necrópolis y la presencia de armas en sus ajuares, se extenderá hacia el Alto Duero, lo que podría estar en relación con el empuje, que antes de la conquista romana conceden los textos grecolatinos a los arévacos, unido al desarrollo del fenómeno urbano (Apiano, Iber., 76). Un número significativo de asentamientos, un $40 \%$, son de nueva creación, mostrando preferencias por ocupar cerros destacados en las amplias llanadas, coincidiendo con suelos pardos, aptos para la agricultura de secano y la mayor proximidad de los asentamientos a los cursos de agua, en los valles fluviales, buscando la complementariedad de las tierras más fértiles del fondo con las posibilidades ganaderas del páramo y los recursos forestales de las riberas de los ríos y de los montes de encinares, pinos y sabinas (Jimeno y Arlegui 1995) (Fig. 6).

En la zona de Tierras Altas, en el reborde montañoso del Sistema Ibérico soriano, seguirán dominando a partir del siglo IV a. C., los lugares elevados sobre el entorno más inmediato, aunque sin superar como en la etapa anterior la altura de $1.300 \mathrm{~m}$, observándose un proceso de concentración de población en núcleos cada vez de mayores dimensiones. No obstante, el 52\% de los poblados no alcanzan la hectárea de superficie; el $32 \%$ tiene entre una o dos hectáreas y el 16\% más de dos hectáreas (Jimeno y Arlegui

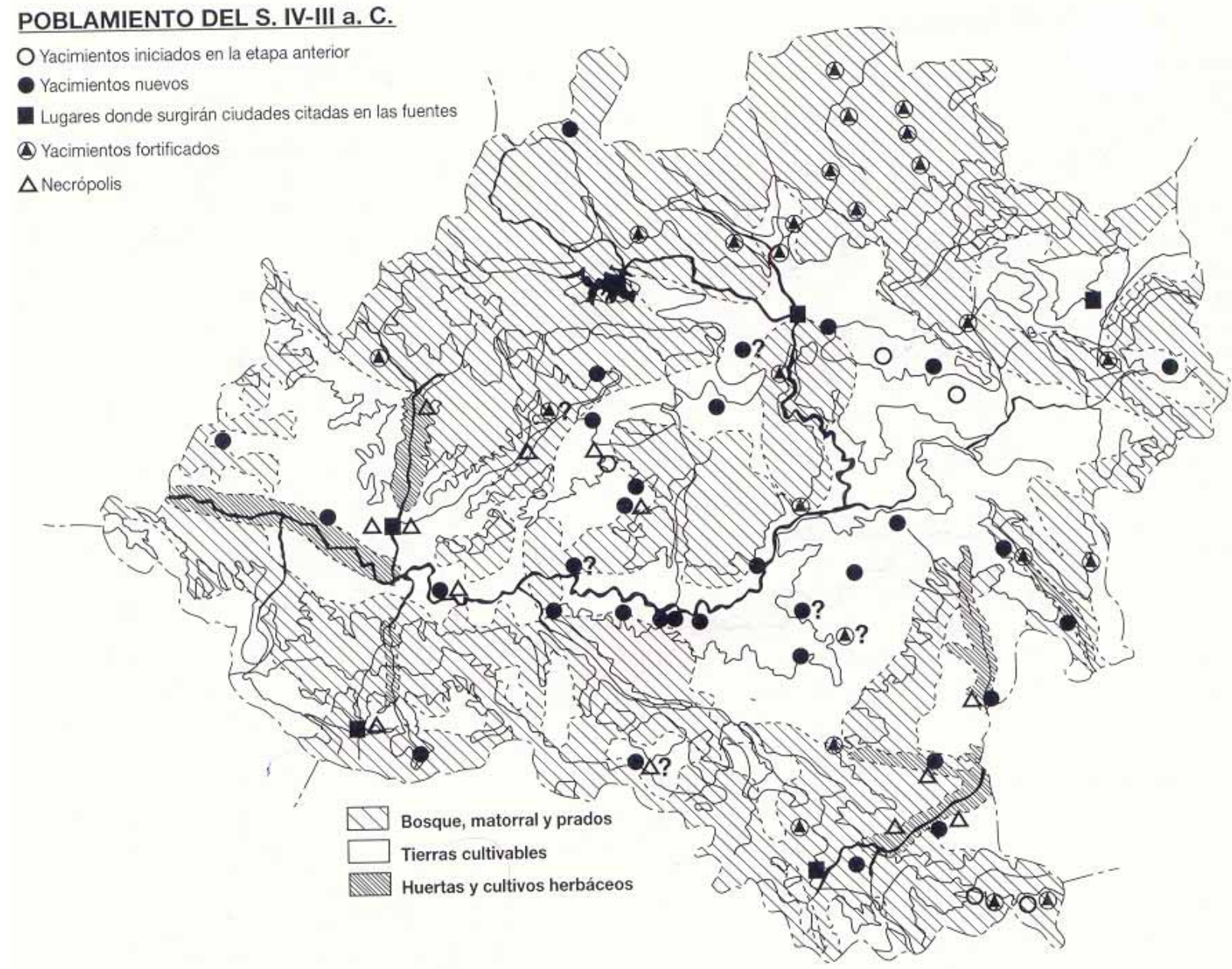

Figura 6.- El poblamiento de los siglos IV-III a.C. y su relación con el aprovechamiento de suelos. 
1995). En el momento inicial y pleno alcanzan su mayor pujanza estos últimos, sustituyendo definitivamente como centros rectores a los viejos poblados del momento anterior. Se acusa una mayor densidad del territorio, ya que se pasa de 25 yacimientos, conocidos en la etapa anterior, a 32 en esta etapa más reciente (Alfaro 2005: 302)

Estos nuevos asentamientos van a incrementar su potencial demográfico a costa de los viejos poblados, aunque, en algunas áreas, estos últimos parecen mostrar cierto vigor, conservando el dominio sobre su territorio, en condiciones de igualdad con los nuevos establecimientos. Algunos de estos poblados supervivientes se dotarán también en un momento avanzado, con sistemas defensivos, a semejanza de los recientemente instalados, protegiendo el flanco más vulnerable del poblado y reforzándolo con foso o bastión o ambos elementos a la vez, como en el Cerro del Haya, Los Castillejos de La Laguna y otros (Alfaro 2005: 3003).

Este incremento de la explotación del territorio y del paulatino proceso de sedentarización romperían la dualidad rebordes montañosos y valles fluviales, limitando el peso, en las zonas serranas, al aprovechamiento ganadero exclusivo. Todo ello debió suponer cambios en el acceso a la tierra y su aprovechamiento, ya que se pasará de la dependencia para la subsistencia de escasos recursos, a establecer ahora territorios y aprovechamientos más diversificados e intensivos, lo que conllevará la necesidad de recurrir al uso de mejoras tecnológicas: arado, rotación de cereales y leguminosas y abonado (Ruiz-Gálvez 1992; Cubero 1999: 58-59), para propiciar el aumento de la producción, que permitiera sostener el crecimiento demográfico, lo que conllevaría el establecimiento de nuevas relaciones de dependencia.

\section{Inicio de las ciudades en el Alto Duero}

Desde finales del siglo IV a. C., pero especialmente durante el siglo III, se observa cómo en las necrópolis del Alto Jalón-Alto Tajo se inicia un proceso de empobrecimiento de los ajuares armamentísticos de sus tumbas (Lorrio 1997). Este empobrecimiento se ve contrasta- do con la realidad, bien distinta, que presentan las necrópolis del Alto Duero, ya que las de Ucero, junto con Osma (Soria) y Arcóbriga (Monreal de Ariza, Valle del Jalón) y ,sobre todo, la recientemente excavada de Numancia (Garray, Soria) evidencian un mayor enriquecimiento desde finales del siglo III y siglo II a. C., pero no centrado en lo armamentístico, sino en otro concepto de riqueza y personalización de la misma, teniendo lugar paralelamente el desarrollo de la economía agrícola, plasmada en asentamientos rurales de aprovechamiento mixto (55\% aprovechamiento ganadero; 39\% agrícola y $27 \%$ forestal), así como, un incremento de la intensificación de los intercambios, en un marco económico más amplio entre la Meseta, el valle del Ebro y la zona mediterránea.

Al menos, desde inicios del siglo III a.C., en zonas próximas del valle del Ebro, se tiene referencia de la existencia de auténticos mercados, como es el caso del poblado de La Hoya (Álava), donde en su área central se han hallado ponderales troncocónicos ( 6 de bronce y uno de hierro), aplicados seguramente a los elementos metálicos, pero tal vez también a otros objetos comerciados en el lugar. Esto viene reforzado por la presencia en territorio celtibérico de importaciones mediterráneas, como vino, aceite o vajillas de mesa (Ruiz Gálvez 2005: 375). Posteriormente, también se conocen ponderales en varias ciudades celtibéricas del valle del Ebro, como Bilbilis (Valdeherrera, Calatayud) y Contrebia Belaisca (Botorrita, Zaragoza) (Medrano 1987: 149; Díaz y Medrano 1987)

Incluso, se ha planteado la posibilidad de la comercialización de productos cárnicos conservados en salazón, en forma de cecina o jamón, a partir de un gran almacenamiento detectado en El Palomar de Aragoncillo (Guadalajara); así como de lingotes de hierro en proceso de semielaboración; es decir pequeñas porciones de metal, ya depurado, a los que bastaría con someter a un simple proceso de forja para su transformación, que podrían ser intercambiados por cuentas de pasta vítrea, broches de cinturón, espadas y falcatas halladas en algunas necrópolis (Arenas 2005: 396).

Se establecerán ahora las condiciones previas para el desarrollo de ciudades, como es la presencia de grupos dirigentes detentadores y 
controladores de la producción de excedentes e intercambios, así como, la existencia de actividades económicas diferenciadas en un núcleo central, que permitieran el desarrollo de actividades comerciales (Galantay 1977: 17; Asensio 1994: 22; Caballero 2003: 18-19), posibilitando el desarrollo artesanal y de servicios, estableciendo en el marco unitario del territorio de las ciudades-estado la complementariedad entre urbano y rural. Los núcleos candidatos a convertirse en ciudades estarán situados en zonas con mejores posibilidades para el aprovechamiento agrícola, con tierras útiles abiertas y bien comunicadas, en las que se aglutina una mayor concentración de población. Este proceso debió ser progresivo, pero no muy dilatado en el tiempo, nutriéndose estos centros de mayores dimensiones, para sus diferentes funciones, con gentes desvinculadas de las estructuras parentales, a las que estaban vinculados social y económicamente, que buscarán su subsistencia en las nuevas formas de producción, estableciendo relaciones de dependencia personal.

Estos cambios quedarán evidenciados progresivamente en un patrón poblacional diversificado, con una tendencia a núcleos de mayor extensión, entre 4 y 6 ha., aunque continuarán dominando los pequeños asentamientos, entre una y dos hectáreas (Jimeno y Arlegui 1995). Según la información textual y arqueológica se puede considerar válida para el inicio de las ciudades, en estas zonas del Alto Duero, la fecha de un momento avanzado del siglo III a. C. (Jimeno 1983; Jimeno y Arlegui 1995), más tardío, que en el marco celtibérico del valle del Ebro, donde el fenómeno urbano se desarrolló a partir del siglo V a. C. (Beltrán 1986; Almagro y Dávila 1995: 227; Burillo 1998: 220). Como ya se ha apuntado anteriormente, hay que relacionar el modelo de la "ciudad estado" celtibérico con un origen mediterráneo, no obstante este modelo fue adaptado por los diferentes pueblos a sus peculiares características organizativas, lo que explica que encontremos diferencias entre pueblos colindantes e incluso entre los grupos de la Celtiberia Citerior y Ulterior.

A partir de finales del siglo III a.C., tendría lugar la fundación de Numancia (como corroboran la fechas de $\mathrm{C}-14 \mathrm{y}$ del resto de las ciudades de la zona del Alto Duero, algunas localizadas, como Uxama y Termes, así como Arecoratas (Muro, Soria), al pie del Moncayo, $\mathrm{y}$ otras cuya ubicación se desconoce, como Occilis, Malia, Lutia o Lagni. La información sobre génesis de ciudades en el contexto indígena está relacionada con procesos de sinecismo. Estos centros u oppida aprovecharían su centralidad y sus buenas comunicaciones, para incentivar su economía, quedando fortalecidos respecto a los poblados de su entorno, viéndose en la necesidad de atraer población, "bien de grado o por la fuerza", para contribuir a su desarrollo, como se refieren las fuentes a la actitud de Segeda, en el episodio que fue la causa de la segunda guerra celtibérica, convirtiéndose así en cabezas jerárquicas de sus ámbitos territoriales (Apiano. Iber., 44).

Este proceso de concentración demográfica está bien documentado en la comarca de Tierras Altas sorianas, donde se han identificado 32 yacimientos, en el conjunto de las cinco zonas naturales del territorio, observándose otros tantos poblados que van a centralizar y controlar cada una de ellas: La Muela de Valloria (en el nacimiento del Cidacos), Los Castillejos/La Veguilla de Villar de Maya en el territorio de Yanguas/ Villar del Río, El Castillo de La Laguna (en el río Baos), Los Casares de San Pedro Manrique (en el Alto Linares), y el complejo del Ambriguela (El Castillejo/Corrales de Sansón/ El Castillo de Vea) en los Barrancos del Linares. Este proceso de concentración y jerarquización espacial parece que no fue conflictivo, sino que muestra un proceso evolutivo, en el que se vieron beneficiados aquellos lugares que reunían las mejores condiciones en ese momento, como eran su centralidad y sus buenas comunicaciones, que contribuyeron a incentivar su economía, convirtiéndose cada uno y de forma "natural" en cabeza jerárquica de su área respectiva. De estos cinco lugares hay que destacar dos que, en el siglo II a. C., centralizarán cada una de las cuencas fluviales, El Castillejo de La Laguna, en la cuenca del Cidacos y Los Casares de San Pedro Manrique, en la del Linares. Sus dimensiones (unas 4 hectáreas más la construcciones extramuros) y sus características (centralidad, ubicación, tipo de emplazamiento, defensas complejas) los convierten en algo más que poblados se trataría de ciudades u oppida (Alfaro 2005: 303-304). 


\section{Las primeras noticias sobre ciudades}

Los escritores romanos, que relatan la crónica de la conquista romana, se refieren, según va avanzando el control de estas tierras, desde el valle del Ebro hacia el interior del Sistema Ibérico, a un territorio celtibérico salpicado de ciudades. Esta información se inicia hacia el 200 a. C. y alude al avance de los ejércitos romanos por el Ebro y a la campaña consular, bajo el mando de Catón, en el 195 a. C., que, según Tito Livio, desmanteló y volvió a someter las ciudades del noreste peninsular, llegando hasta una Seguntia Celtiberorum y, de creer a Aulo Gelio, hasta la propia Numancia. Pero esta cita siempre ha suscitado serias dudas, aunque recientemente la revisión de la numismática de los campamentos romanos de la Atalaya de Renieblas, junto a Numancia, parece aportar datos para ello (Jiménez 2010). En este sentido, se admite la posibilidad de que esta expedición tenía como objetivo examinar las posibilidades económicas de la Hispania hasta entonces inexplorada y valorar la conveniencia de extender la conquista y analizar sus dificultades, hasta el punto que la política de Catón debió producir un cambio en el desarrollo del mundo celtibérico a juzgar por los conflictos que a partir de ahora les enfrentan con los romanos (Pina 2006: 73).

Los avances romanos, en 188-187 a.C., bordearon las elevaciones de los sistemas Ibérico y Central, alcanzando Calagurris (Calahorra, La Rioja), aguas arriba del Ebro, y disponiendo su base en los extremos de Corbion y Segeda (El Poyo de Mara, Zaragoza). Se citan también las ciudades de Contrebia, Seguntia y Ercavica cuyas ubicaciones ofrecen dudas, ya que se conocen varias ciudades con el mismo nombre en diferentes zonas y pertenecientes a distintos pueblos (Burillo 1998). La conquista romana y las sucesivas líneas de frontera favorecieron a su vez la fundación de nuevas ciudades, surgidas de las necesidades y el nuevo marco establecido por la conquista. Así, Diodoro (XXIX, 28) y Apiano (Iber. 42) se refieren con motivo de las acciones de Fulvio Flaco, en el 181 a. C., que llevó a cabo una expedición de saqueo por la Celtiberia, asaltando muchos poblados fortificados (castella), sometiendo una buena parte de la Celtiberia, a la recién fundada y fortificada ciudad de Complega (cabe la duda de que se trate de la Contrebia citada por Apiano), que había crecido rápidamente con iberos fugitivos del ejército romano y lusones derrotados por este general; es decir, gentes de origen diverso, que carecían de tierras, se asientan en terreno de nadie, controlando los intercambios entre ambas partes y realizando acciones armadas a uno y otro lado como medio de vida (Domínguez Monedero 2005: 286).

Las acciones anteriores y la batalla de Mons Caunus (posiblemente el Moncayo), en el 179, llevó al tratado de Graco, considerado modélico y de gran duración, que limitó a los indígenas la construcción de ciudades y conllevó la implantación de un sistema legislativo y tributario. Se fundó una nueva ciudad, Gracurris (en el yacimiento de Las Eras de San Martín, Alfaro, La Rioja), en la desembocadura del río Alhama, para proteger la frontera del territorio conquistado. A la marcha de Graco de la Península, quedaba todavía fuera del control romano el Alto Tajo, Alto Jalón y Alto Duero (García Riaza 2006: 91).

La nueva situación y la relativa calma aportada por el tratado permitió establecer transacciones e intercambios normalizados, lo que conllevó la emisión de las primeras monedas por algunas ciudades celtibéricas, como Sekaiza, bien datada en la primera mitad del s. II a.C. (169/158 a. C.), y un segundo grupo encabezado por Areikoraticos con Loutiscos, Oilaunicos y Calacoricos (identificada con Calagurris). Estas acuñaciones, como indica Burillo (1995 y 1998), señalan ya una jerarquía entre ciudades reflejada en las que emiten denarios o moneda de plata, como Sekaiza y Areicoraticos, y las que solamente pusieron en circulación bronce, situando por debajo a las que no acuñan. No obstante, esta ordenación, no tienen por qué responder a la importancia que tenían las ciudades celtibéricas, ya que Roma podría haber compensado con estas concesiones a aquéllas que le habían prestado su apoyo (Caballero 2003: 20).

Areikoraticos, situada por lo general en el entorno del Moncayo, y Sekeiza, identificada con Segeda, serán las bases del ejército romano para continuar la conquista (Apiano Iber., 42.; Diodoro, 5, 35,4) del Sistema ibérico, concediéndoles a ambas la acuñación de moneda de plata. La ubicación de Segeda se ha establecido 
en El Poyo de Mara (Zaragoza), perteneciente a los belos (Burillo 2006: 203). La ubicación de la primera de estas ciudades se ha realizado recientemente, en el pueblo de Muro (Soria), situado al pie del Moncayo, que posee veneros de mineral de hierro y de plata, con restos de un amplio asentamiento celtibérico con abundante cerámica de barniz negro y donde recientemente se ha hallado una tésera de hospitalidad (Jimeno et al. 2010). Su ocupación debió estar vigente, como indican sus monedas (Fig. 7), hasta la primera mitad del s. I a. C.; posteriormente, encima de ella se edificó la ciudad de Augustobriga, en época de Augusto (Saavedra, 1861).

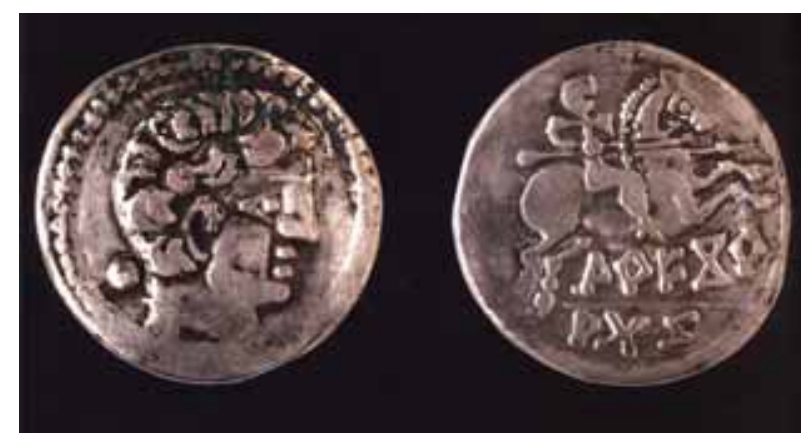

Figura 7.- Denario de la ceca de Arekoratas (Muro, Soria).

Este periodo de relativa calma finalizará con el inicio de la segunda guerra celtibérica, desencadenada por la ciudad de Segeda, que en el año 154 a.C., obligada por el aumento de su población, decidió ampliar su recinto, construyendo una muralla más grande, procediendo a remodelar su territorio, congregando en la ciudad, de grado o por la fuerza, a los pobladores de los alrededores, lo que lleva a suponer que esta ciudad había alcanzado un gran desarrollo y aspiraba a someter bajo su control a las poblaciones de su entorno. Roma interpretó que estas actuaciones contravenían el tratado de Graco (179 a. C.), por lo que envió un ejército al frente de Nobilior, obligando a los segedenses a buscar refugio en Numancia, donde fueron acogidos, según Apiano (Iber. 45), como "aliados y amigos" y añade Floro $(1,34,3)$ que "de esta manera tan injusta entró Numancia en la guerra".

La primera fase de la guerra celtibérica (entre el 154 y el 150 a.C.), que supuso para Roma el control del valle del Jalón, se desarrolló en tor- no a la cuenca de este río y en el Alto Duero, ya que se citan ciudades como Nertobriga (se ha propuesto en los términos de Calatorao o $\mathrm{La}$ Almunia de Doña Godina, Zaragoza), Segeda, Numancia y otras no identificadas, como Axinio y Occilis. La segunda fase (143-133 a.C.) se centra más sobre el valle del Duero, citándose Pallantia y Numancia. Las campañas de Metelo, entre 143-142 a.C., consiguieron someter, según Apiano (Iber., 76), las ciudades arévacas, a excepción de Termes y Numancia. Floro $(1,34)$ vuelve a mencionar Nertobriga, en la zona del Jalón medio, Contrebia Leucade (en Inestrillas, Rioja) y Centobriga, sin ubicación concreta. Apiano (Iber.,76) refiriéndose a la campaña, poco afortunada de Pompeyo, realizada entre 141-139 a.C. en el Alto Duero, cita Numancia y Termes, asÍ como Malia y Lagni, en los alrededores de Numancia, pero sin que hayan podido ser ubicadas (Jimeno y Arlegui 1995; Burillo 1998).

La conquista romana de esta zona (Fig. 8 A-B) establecerá un nuevo marco paisajístico, ya que el avance de los campamentos militares marcará las líneas de frontera o el limes de lo conquistado, así como los caminos de penetración y abastecimiento en relación con las zonas del valle del Ebro. Al hilo de esta conquista se irán fundando también ciudades fronterizas para compensar a los veteranos con el reparto de tierras. La raya, estabilizada a lo largo de veinte años (desde el 153 al 133 a.C.), como consecuencia de la resistencia numantina, estará marcada de norte a sur, sin sobrepasar la cabecera del Duero, por los campamentos de La Atalaya de Renieblas, a ocho kilómetros de Numancia, y los de Almazán y Alpanseque, en la provincia de Soria; así como el de Aguilar de Anguita, en Guadalajara (Jimeno 2006: 175).

Cada vez más la guerra se centra sobre Numantia (Garray, Soria), así la campaña de Mancino, en el 137 a.C., se desarrolla sólo sobre esta ciudad, aunque, posteriormente, Lépido y Pisón, entre el 137-134 a. C. se trasladan a Pallantia. Tendrá lugar, finalmente, la campaña de Escipión entre 134 y 133 a.C., que accede a Numancia por el territorio caucense (Coca, Segovia), para establecer su férreo cerco en torno a esta ciudad. Se cita también la ciudad de Lutia (situada a unos 57 $\mathrm{km}$ de Numancia), a donde el jefe numantino 


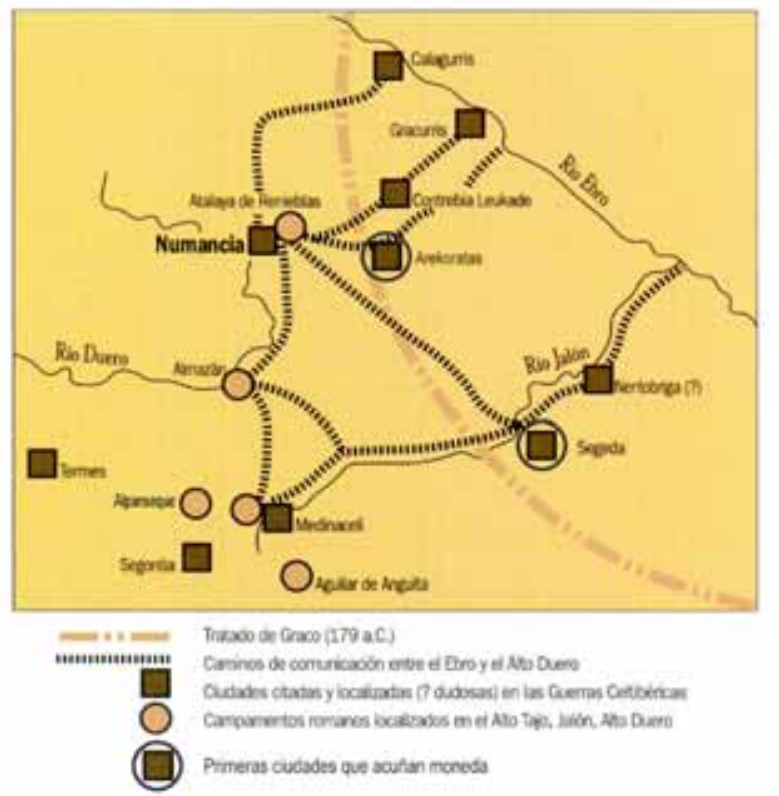

Figura 8A.- Conquista del Alto Duero.

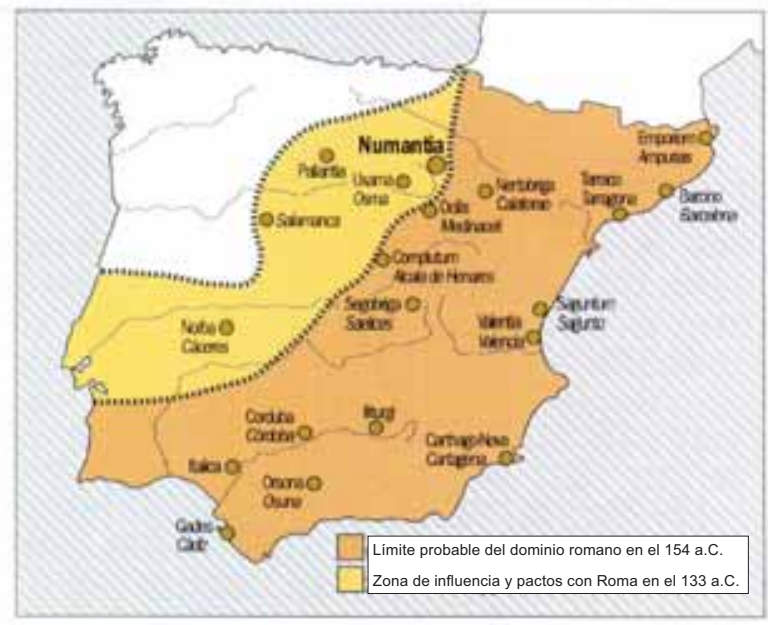

Figura 8B.- Fases de la conquista romana.

Retogenes acude en busca de ayuda, tras burlar el cerco escipiónico, pero no conseguirá evitar el fin de la resistencia numantina, que supuso el control del Alto Duero.

\section{Las ciudades y sus problemas de localización}

Los nombres de las ciudades celtibéricas nos han llegado por diferentes vías: a través de documentos epigráficos sobre inscripciones en soportes duros, como las téseras de hospitalidad y otros documentos sobre bronce o cerámica; un buen número de ciudades se conocen porque acuñaron moneda con su nombre $\mathrm{y}$, también, al ser citadas en los textos de los historiadores romanos; no obstante, su relevancia puede estar un tanto sesgada por su implicación en los conflictos bélicos que se narran, mientras que otras ciudades, aunque pudieran ser importantes, serían silenciadas al no participar en las guerras comentadas (Caballero 2003: 20). Por lo tanto, a veces, el nombre de una ciudad se conoce por diferentes vías, así Bilbilis, que acuña moneda con su nombre, es citada en los textos clásicos y aparece su inscripción en un mosaico hallado en Andelos (Navarra). Pero es frecuente, que el nombre de una misma ciudad, aparezca citado en distintos documentos con diferentes grafías, lo que obliga a dudar si se trata de la misma localidad.

Un grupo de ciudades sólo son mencionadas en los textos clásicos: Numancia, Termes, Occilis, Contrebia Leucade; otra, Cortona, además de citar Plinio a sus habitantes, aparece en una tésera de hospitalidad (Fatás 1985). Algunas sólo se recogen en textos indígenas, como Arekoratas, citada en el bronce de Luzaga $\mathrm{y}$ en una tésera de hospitalidad, Belikiom, inscrita en una estela funeraria, o Orosis, grabada en el santuario de Peñalba de Villastar (Teruel). Pero existe otro grupo que conocemos sólo por las monedas: louitiskos, oilaunikos, olkairun, kaisesa, okalakom, que, aunque no son citadas en los textos, debieron tener su importancia por el hecho de acuñar moneda (Fig. 9), pudiendo originarse después de las guerras celtibéricas (154-133 a.C.) sin llegar a alcanzar la época de Augusto.

En la Celtiberia Ulterior, en el marco del Alto Duero y los rebordes hacia la vertiente del Ebro, las ciudades celtibéricas que han podido ser ubicadas con seguridad son Uxama Argaela (Osma, Soria), Termes (Montejo de Tiermes, Soria) y Segontia Lanca (Langa de Duero, Soria), Clunia (Peñalba de Castro, Burgos), atribuidas a los arévacos; Numantia (Garray, Soria), que es arévaca en Estrabón y Ptolomeo y pelendona en Plinio (Taracena 1954: 202); además las ciudades de Contrebia Leukade (InestrillasAguilar del Río Alhama, La Rioja) y Arekoratas (Muro, Soria), situadas entre los pelendones, a caballo entre el Alto Duero y el valle del Ebro (Taracena 1954: 202). También se ha incluido la ceca de Sekobirikes, todavía no identificada con seguridad, pero puesta en relación con 


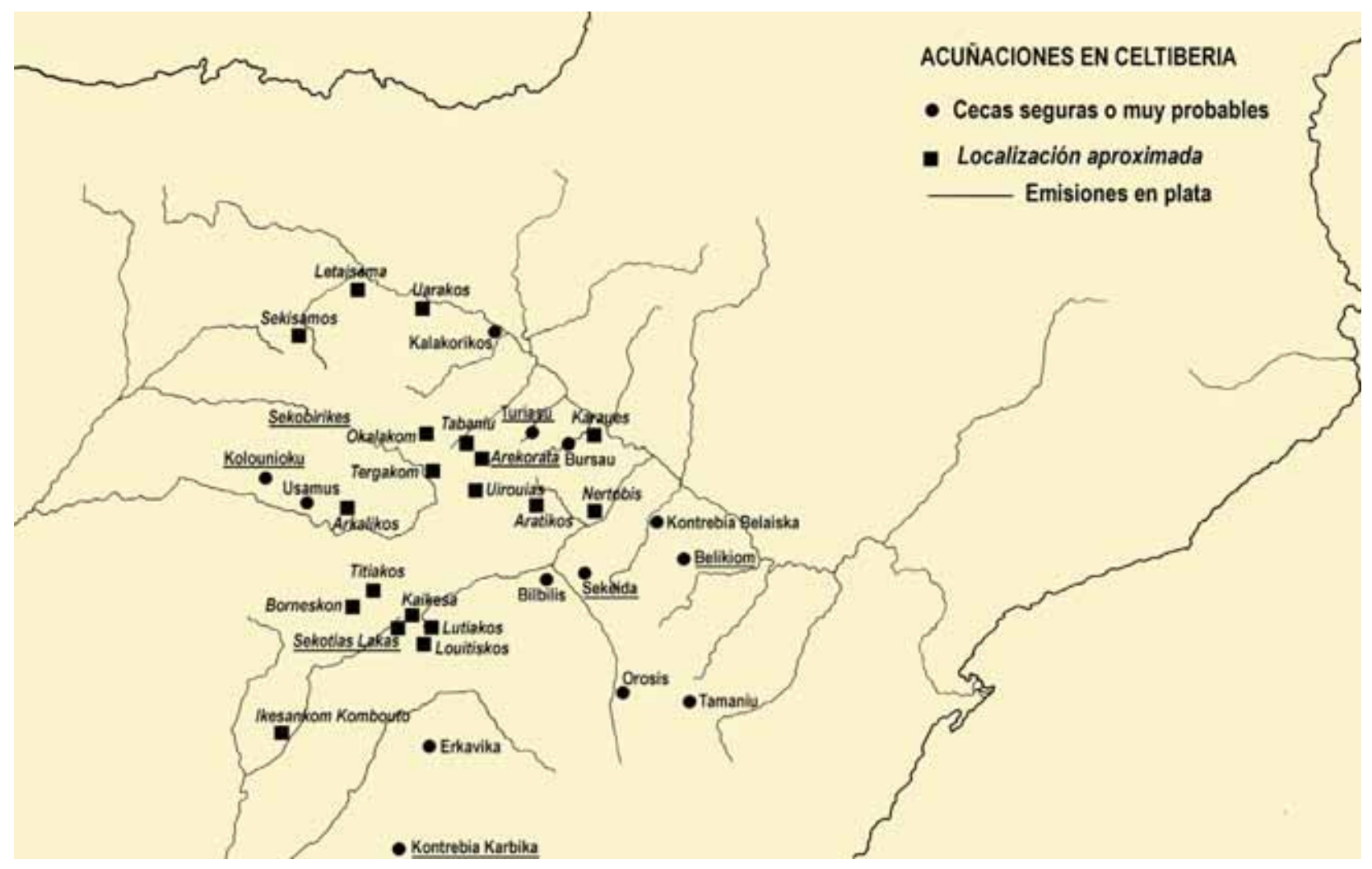

Figura 9.- Mapa con las ciudades celtibéricas que acuñan moneda (Domínguez Monedero 2005).

Pinilla Trasmonte (Burillo 1998: 191-193). A excepción de esta última las anteriores tienen una larga tradición de investigación y fueron identificadas desde antiguo. Finalmente, se incluyen también referencias a las ciudades de Occilis y Voluce, identificadas respectivamente con Medinaceli y el cerro de Los Castejones de Calatañazor, ambas en la provincia de Soria, ya que las revisiones que se han realizado de ellas, más recientemente, no avalan estas propuestas:

\subsection{Numantia}

Es la ciudad más citada por los historiadores de la antigüedad y situada como mansión en la vía XXVII del Itinerario de Antonino (corresponde a un momento posterior, s. III d. C.), entre Augustobriga y Voluce. Fue identificada en el cerro de La Muela de Garray (Soria), ya desde el Renacimiento por Antonio de Nebrija y reforzados los argumentos por Ambrosio de Morales (s. XVI) y Mosquera de Barnuevo (1612), facilitando el primer croquis de sus ruinas Loperraez (1780). Se acometieron las primeras excavaciones en 1803 , pero serán los trabajos de Saavedra sobre la vía romana los que aporten los argumentos científicos de su adecuada ubicación (Saavedra 1861) y los que impulsarán las primeras grandes excavaciones acometidas por la Real Academia de la Historia (1861-1867).

Numancia se asienta en un alto y amplio cerro en las confluencias de los ríos Tera y Merdancho con el Duero, que se eleva a una altura de $1.080 \mathrm{~m}$ sobre el nivel del mar y a unos $67 \mathrm{~m}$ por encima del cauce del río Duero, lo que le proporciona un amplio control estratégico, dominando todo el reborde del Sistema Ibérico y los caminos de comunicación entre el valle del Ebro y el Duero (Fig. 10).

\subsubsection{Urbanismo}

$\mathrm{Su}$ urbanística se adapta perfectamente a la configuración del cerro, que remata en una amplia plataforma, a la que se acomoda el límite de su caserío y línea defensiva, establecida al inicio de la pendiente más brusca. Su amplia superficie excavada, unas 6 ha, informa par- 
cialmente del trazado y organización de la ciudad celtibérica, ya que a ésta se le superpone la ciudad de época romana. En conjunto se han descubierto algo más de 19 calles y 20 manzanas. La ciudad, con su centro ligeramente desplazado hacia el oeste, se estructura en torno a dos largas calles paralelas dispuestas de norte a sur, cruzadas por otras 11, también paralelas entre sí, de dirección este-oeste, formando una retícula irregular, sin dejar espacios libres como plazas o lugares de encuentro. Esta cuadrícula queda circundada al occidente por una calle paralela a la muralla, que continúa hacia el interior por el sur, en donde existen otras tres calles por delante y paralelas a ella que forman anillos concéntricos exteriores, reflejo de sucesivas ampliaciones urbanas. La ciudad estaba bien planificada para evitar las inclemencias del tiempo, con sólo dos calles en dirección norte-sur y, en las intersecciones, el trazado de las calles es quebrado para cortar las corrientes de aire. Nada lleva a pensar que la ciudad se extendiera fuera de su recinto murado en época celtibérica, lo que no impide la existencia de construcciones ocasionales o aisladas.

Las calles celtibéricas son más irregulares en su ejecución y trazado que las romanas superpuestas. En este sentido hay que destacar la diferencia de anchura que se aprecia en los distintos tramos de una misma calle, ya que podemos encontrar zonas con una anchura de 5'38 m., de los cuales 4 corresponden al arroyo, y otros tramos con sólo 3’30 m., de los cuales $2 \mathrm{~m}$. son de arroyo y el resto de aceras. Están empedradas con cantos rodados de desigual tamaño, con predominio de los más grandes, que muestran, en ocasiones, las huellas dejadas por el paso de los carros. Las aceras son de tierra y solamente sus bordes se ven reforzados por grandes cantos sin labrar.

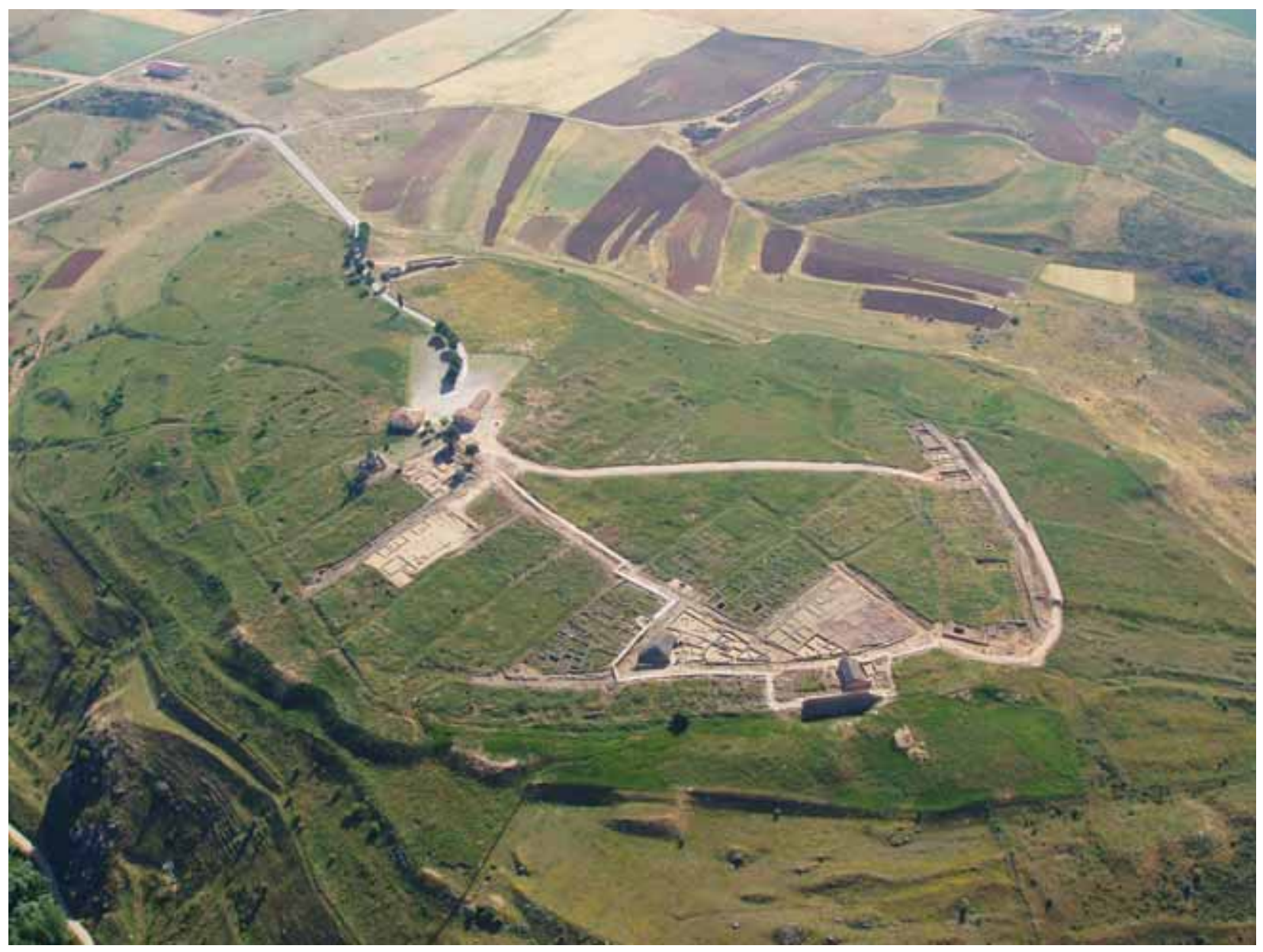

Figura 10.- Vista aérea de Numancia con su trama urbana. 


\subsubsection{Sistema defensivo}

Los trabajos arqueológicos del siglo XIX y principios del XX (Saavedra 1861, Schulten 1945 y González Simancas 1926) pusieron al descubierto distintos lienzos de muralla en diferentes lugares de las zonas oriental y occidental, que permiten conocer sus características. Los tramos descubiertos -el más largo, de unos 180 m., es el del lado noroeste- muestran una muralla de distinta anchura en la base -que oscila entre los 3'40 m. en el lado este, $4 \mathrm{~m}$. en el lado noreste, y 5'70 m. en el noroeste-, construida a base de cantos rodados gruesos, reforzada a intervalos con torres cuadradas, de $3 \mathrm{~m}$. de salida. Algunos paramentos exteriores estaban construidos con sillarejos, pero por lo general se utilizaron grandes cantos rodados sin trabajar, los mismos que se emplearon para el relleno, unidos con barro. En una amplia zona se ve reforzada por una espina longitudinal central de cantos rodados de mayor tamaño, reforzada por muros transversales, lo que se conoce como técnica de cajones. Saavedra calculó una altura para esta muralla de $6 \mathrm{~m}$. La muralla no era uniforme en todo su perímetro, ofreciendo menos consistencia en los lados sureste y oeste, en donde el cerro ofrece mejores defensas naturales; así mismo en unas zonas, como la noreste, presentaba casas adosadas, como ocurre en general en los poblados celtibéricos y de la Edad del Hierro, mientras que en otras aparece enmarcada por una estrecha calle de ronda.

La muralla de Numancia, además de adaptarse a las características estratégicas que presenta su topografía, acusa también los cambios urbanísticos y la reconstrucción de ciudades llevada a cabo. Estos cambios son menores en la zona oriental y nororiental, en donde la existencia de una alineación natural única condiciona constantemente el establecimiento de la muralla; por el contrario, son más evidentes en la zona sur y suroccidental, por ser este lugar, de pendiente más prolongada y más protegida, donde se observan las ampliaciones más significativas. En esta potente muralla se abrían cuatro puertas principales, bien defendidas, de las que conocemos sólo dos, una en la zona norte, en forma de codo, y otra en el lado occidental, protegida por una torre triangular, que conserva todavía restos de la escalera de acceso.

\subsubsection{Espacios domésticos}

Los datos que nos ofrecen las excavaciones, para conocer las características de las viviendas celtibéricas anteriores al 133 a.C., son escasos, ya que debieron ser arrasadas por las reconstrucciones posteriores de la ciudad. Las excavaciones de Schulten (1945: 29) proporcionaron, adosadas a la muralla de poniente (Manzana IV), una serie de casas celtibéricas que nos permiten conocer sus características y compartimentación, que, por otro lado, no se alejan de las conocidas en otros yacimientos similares.

Sus plantas, por lo general, eran rectangulares o trapezoidales (unos $70-80 \mathrm{~m}^{2}$ con la estancia subterránea y el corral) y su basamento estaba realizado con mampostería, a base de grandes cantos, bien dispuestos por su cara plana, o bien ligeramente trabajados; por el contrario, el alzado de las paredes y los muros interiores, separadores de estancias, se construían con postes de madera -se han hallado restos quemados de pino, roble, álamo, sauce y fresno- y los espacios entre ellos se cubrían con muros de adobe o tapial, de unos 30 a $45 \mathrm{~cm}$ de grosor. Las paredes estaban enlucidas con barro y cal, y la techumbre realizada con armadura de madera, que apoyaba sobre los postes de las paredes, y cubrimiento de ramaje sujeto a veces con barro y en algunas zonas, sobre los muros, con lajas de piedra. Estas casas, que tendrán continuidad en la etapa siguiente, tienen como habitación característica la estancia subterránea o cueva, destinada al almacenamiento y conservación de los alimentos.

\subsection{Uxama Argaela}

Al igual que Numancia es citada como mansión en la vía romana, número XXVII del Itinerario de Antonino, entre Clunia y Voluce, y atribuida por los autores clásicos a los arévacos. Será E. Saavedra (1861) quien aporte los argumentos científicos, en su estudio sobre la vía romana, para situarla en el cerro de El Alto del Castro de Osma (Soria). El topóni- 
mo antiguo Uxama ha perdurado en la actual Osma y la diócesis eclesial, a través del termino intermedio hispano-visigótico de Oxama. La grafía usama aparece por primera vez en una tésera de hospitalidad celtibérica, del siglo I a.C. El topónimo de la ciudad va seguido de un etnónimo, que debe aludir a la gens que sería la que ocupaba estas tierras (García Merino 2005: 177-178).

El Alto del Castro, donde se sitúa con seguridad la Uxama romana, está constituido por dos amplios cerros separados por una profunda vaguada que desciende hasta el río Ucero. Desde su emplazamiento estratégico se dominan visualmente los rebordes del sistema Ibérico por el norte y las estribaciones del Sistema Central por el sur. Aunque se ha planteado la posibilidad de que la Uxama celtibérica se pudiera localizar en otro sitio, hay argumentos suficientes para mantener su localización en este lugar. Un referente importante es la existencia de sus dos necrópolis celtibéricas (El Portuguí y Fuentelaraña), separadas $2 \mathrm{~km}$, y situadas una al sur (más alejada de la ciudad) y otra al norte, en la ladera del cerro, que estarían enmarcando el núcleo de población, determinando la ubicación de la ciudad celtibérica y su continuidad, ya que se mantuvieron en uso hasta la mitad del siglo I d.C. No obstante, aunque los restos prerromanos no permiten remontarse con seguridad al siglo II a.C., se situaría su foco inicial de ocupación en el extremo sudoriental, marcando el límite del oppidum prerromano, por el zona sur, dos torres prismáticas flanqueando una puerta $\mathrm{y}$ un cuerpo de guardia, muy alterados por construcciones posteriores de época romana. Por otro lado diferentes restos de casas fechadas en época tardoceltibérica, halladas por debajo de construcciones altoimperiales, localizadas en un barrio extramuros, junto a la población de Osma, avalarían su continuidad (García Merino 2005: 178).

Esta ciudad acuñó moneda de bronce, con cabeza masculina en el anverso, acompañada por delfín o arado, y jinete lancero en el reverso, con las leyendas arkailikos/us y usamus. Las monedas de la primera leyenda corresponden al primer cuarto y mediados del s. I a.C.; las acuñaciones con la segunda leyenda, más numerosas y de peor calidad de ejecu- ción son más tardías. Esta ciudad se inclinó en las Guerras Sertorianas por la causa de éste (García Merino 2005: 181).

Se halló en el castro una tésera de hospitalidad, con forma de lechón y realizada en bronce, que documenta un hospitium entre los uxamenses y otra comunidad. Está escrita por una de sus caras y perforada para ser suspendida. El texto en escritura celtibérica occidental se ha fechado en un momento avanzado del siglo I a. C.: (documento) de Borbodunum (o Tarvodurum). Pacto de hospitalidad en Uxama para los extranjeros que viven sobre el Duero, estando presente (o actuando como legado) Segio, hijo de Baeso, del linaje de los Caldaecos, según interpretación de Untermann y Jordán (García Merino 2005: 181-182). Aplicando la teoría de "el vecino más próximo" se ha realizado una aproximación a la zona de explotación de recursos de Uxama. En esta área la distancia entre poblados sería de en torno a $16 \mathrm{~km}$ en sentido norte-sur (entre Ucero y Uxama o entre Uxama y Gormaz) y de $30 \mathrm{~km}$ en sentido este-oeste (entre Uxama y La Mercadera o Uxama y Langa). Se estimaría así para Uxama un territoro de explotación de un entorno de $120 \mathrm{~km}^{2}$, durante los siglos III-II a.C. (García Merino 2005: 178).

\subsection{Termes}

También denominada como Termantia por Apiano (Iber., 99), se cita por vez primera el año 143 a. C., en unión de Numancia, como ciudades no sometidas a Roma. Es aludida después por diferentes autores romanos, conociéndose su última cita en el Ravenate (s. VII d.C.). Este topónimo se ha mantenido con la variante Tiermes (Santa María de Tiermes), a partir de la Edad Media hasta el momento actual, lo que ha propiciado su fácil localización (Taracena 1941: 102). La documentación epigráfica conocida, indica que el topónimo de la ciudad era Termes, como se puede observar en la tésera de bronce, hallada en Peralejo de los Escuderos, escrita en latín que cita "populo termestino" (D'Ors 1951: 576-578), así como en otra tésera de hospitalidad entre un uxamense y un termestino (García Merino 1980). 
Se asienta en un alto cerro (1.234 $\mathrm{m}$ sobre el nivel del mar y $84 \mathrm{~m}$. de cota sobre la llanura) de forma elipsoidal en dirección este-oeste (770 m por $365 \mathrm{~m}$ ), que se eleva sobre el pequeño río Manzanares o Tiermes. Su posición geográfica en las estribaciones de la Sierra Pela (vertiente norte de la cordillera Carpetana), al sur del territorio arévaco, la alejaban de las comunicaciones con el Alto Duero, posibilitando una mejor relación con el Alto Henares, hacia las tierras de Atienza (Guadalajara). Hay que destacar la cita que realiza Apiano, en el año 97 a. C., describiéndola como ciudad de acrópolis enriscada y burgo de fáciles laderas, cuando el cónsul Tito Didio conquista Termesos y hace bajar a sus habitantes al llano. Pero esta cita parece no ajustarse a la información arqueológica, interpretándola Taracena como excesiva, ya que apoyándose en la información de sus excavaciones, entiende que los termestinos se limitaron a dejar la acrópolis y vivir en las laderas no fortificadas (Taracena 1941: 103). Se ha querido vincular con esta ciudad la ceca de BormesKom/ Bormesko, situada hacia el área sedetana o entre el Alto Duero y el Jalón, que acuñó moneda a finales del siglo II e inicios del siglo I a.C., a través de una nueva propuesta de lectura de Jordán: TArmesKOm/ TArmesKO, que la relacionaría con Termes (Martínez y Mangas 2005: 174).

La referencia arqueológica celtibérica más clara para este yacimiento es la necrópolis de Carratiermes, a unos $900 \mathrm{~m}$ al este del núcleo urbano, que tiene una larga duración, desde el siglo VI a.C. al siglo I d. C., lo que mostraría un comportamiento similar a lo planteado con las necrópolis de Uxama. Sobre los aspectos urbanísticos del oppidum los datos son sumamente escasos, quizás la puerta del Oeste, excavada en la roca con imponente tajo, alguna estructura doméstica rectangular con tres estancias y silos (Jimeno y Arlegui 1995: 116), en la parte superior, y algunos discuten el templo en la cumbrera de la acrópolis y la posibilidad de que el graderío, junto a la entrada de la puerta del Sol, fuera para reunir la asamblea o comitium de la ciudad celtibérica (Almagro-Gorbea y Berrocal 1997: 575577; Martínez y Mangas 2005: 172-173).

\subsection{Segontia Lanka}

Taracena situó esta ciudad en la Cuesta del Moro, al sur de la villa de Langa y a dos kilómetros del Duero, conjugando la cita de Estrabón, de que el Duero pasa junto a Numantia y Sergontia, y la de Ptolomeo que sitúa Setortia Lacta entre las ciudades arévacas del convento jurídico de Clunia, entre esta ciudad, la de Termes y Vxama, lo que en unión de la leyenda de las monedas "SEGoTiAS LAGaS" permite situarla junto al Duero, que encuentra acomodo fonético con el nombre de Langa, el pueblo actual (Taracena 1941: 90). También se halló una inscripción sobre piedra, que se encontraba embutida en la pared de una majada, situada en lo alto de la Cuesta del Moro, cuyo texto se transcribiría R.T.U.Ke.N.O. E.S.To (Ke).L.Ti.S, e interpretada como una estela sepulcral de un vecino llamado Retugenos, nombre bien conocido en el mundo celtibérico (Taracena 1941: 89; Arenas y De Bernardo 2001).

\subsubsection{Urbanismo}

Los restos de esta ciudad ocupan un amplio cerro en espigón, situado en la confluencia del arroyo Valdanzo con el Duero. En este lugar llevó a cabo excavaciones arqueológicas Taracena (1941: 89), que al no detectar restos de muralla que le permitieran delimitar el área de la ciudad, pensó que se trataba de una ciudad abierta. Según estos trabajos dedujo que no era ciudad de viviendas compactas, sino una yuxtaposición de caseríos aislados.

Recientes trabajos arqueológicos han venido a reorientar la interpretación de este yacimiento (Tabernero et al. 2005: 197), desestimando la interpretación que del caserío de la ciudad hizo Taracena. Se han podido diferenciar en este amplio cerro, al menos, tres zonas o sectores: Las Quintanas, donde se ha identificado un posible recinto murado; la superficie o el espacio existente entre las dos líneas de muralla descubiertas y, además, en la zona alta se diferencia un tercer sector, al pie del pico y al borde del páramo, La Cuesta del Moro, donde Taracena excavó, poniendo al descubierto los grupos de viviendas comentados anteriormente, lo que le llevó a decir que este yacimiento mostraba "extensión considerable, muy supe- 
rior a la normal en los poblados celtibéricos". Los trabajos recientes aportan además la existencia de casas adosadas a la muralla.

\subsubsection{Sistema defensivo}

En la zona noreste, diferentes evidencias han permitido delimitar un área rectangular, de unas 14 ha de superficie, ocupando las plataformas bajas y las laderas que caen hasta la vega, que debió estar rodeada de un recinto amurallado, que se puede seguir sólo en parte. Se han podido diferenciar restos de dos recintos murados, que dejan una franja entre ellos de unas 10 ha. Uno de ellos en el extremo suroeste de un espigón destacado sobre la vega de río Valdanzo, del que se han descubierto $18 \mathrm{~m}$ de una muralla construida con grandes sillares calizos, de los que sólo se conserva una hilada; así como restos de su cimentación excavada en la roca, con una anchura de $2,5 \mathrm{~m}$, con casas adosadas a la muralla. Un segundo recinto defensivo discurre paralelo al cierre sur del primero, señalado por un pequeño tramo de muralla, con $2 \mathrm{~m}$ de altura, conservando nueve hiladas de sillares, de la que se ha podido determinar su zanja de cimentación. Junto a él se localizaron restos de áreas domésticas (Tabernero et al. 2005: 200202).

En el espacio comprendido entre ambos recintos murados, se han documentado restos cerámicos pasados de cocción y escorias, al pie de Las Quintanas, que mostrarían actividades artesanales relacionadas con estos materiales. En algunas zonas al sur y sobre todo en una próxima a la vega, en el fondo del barranco de San Cristóbal, se han localizado manchones cenicientos, que se han interpretado como basureros, similares a los que se conocen en el área vaccea.

\subsubsection{Espacios domésticos y aspectos socieconómicos}

Según Taracena, las casas eran de una sola planta, estarían dispuestas en crujía con una sola habitación por fondo y tenían en algunas ocasiones el tramo inferior soterrado o excavado en la roca. El recrecido de las paredes estaba realizado en mampostería o con encestado vegetal recubierto de manteado de barro. Los muros interiores eran de barro y la cubierta vegetal con tierra apisonada encima.

En las construcciones se encontraron numerosas pesas de barro que indicaban abundancia de telares domésticos, armas: lanzas, jabalinas, philum, soliferreum y falarica de hierro, glandes de plomo, así como algunas espadas, una de antenas atrofiadas y otra del tipo La Tène III, que acreditan una población en armas. También se encontraron muchas herramientas para trabajos agrícolas y forestales: hoces, y muchos vasos celtibéricos con decoración rehundida de casquetes esféricos radiados de puntos, así como vasos pintados con animales o temas geométricos, monedas indígenas del tipo del jinete (plata y bronce), que estarían destinadas probablemente, al pago de los contingentes de tropas combatientes en el bando sertoriano. Hay que destacar algunos objetos vinculados a costumbres romanas, deducidas por la presencia de ánforas para el transporte de vino, halladas en algunos sótanos de la ciudad, y la presencia de tazas o vasos de cerámica campaniense para su consumo (Tabernero et al. 2005: 2003).

\subsubsection{La cronología}

No se puede concretar con precisión el origen de la ciudad, pero el estudio de los materiales, que guardan gran uniformidad en todas las zonas, parecen indicar una ocupación sincrónica de las diferentes áreas definidas. Así, las monedas celtibéricas acuñadas en la ciudad, en contra de la cronología dada por Taracena, se fechan a caballo del siglo II-I a.C.; la cerámica romana apunta también a este cronología. Todo ello se ve ratificado por la fecha de C-14, aportada por el análisis de una viga de madera (100+/-35 a.C.). A esto hay que añadir la ausencia de cerámica sigillata romana, así como monedas con leyenda latina, de un momento posterior, correspondientes a época imperial romana (Tabernero et al. 2005: 204).

\subsection{Clunia}

Los textos antiguos no ofrecen ninguna referencia sobre la ubicación de esta ciudad celtibérica, salvo su pertenencia al grupo arévaco 
(Ptolomeo, 2, 6, 56), su situación en el límite de la Celtiberia (Plinio, 3, 27), su proximidad o relación con los vacceos y con las monedas con la leyenda CoLOUNIOCu. Fue asediada por Pompeyo en las Guerras Sertorianas ( 75 a.C.), ya que Sertorio se había refugiado en esta ciudad y tres años después, muerto ya este, fue tomada. En el año 56 a.C. se unió al levantamiento de las ciudades vacceas. Los restos arqueológicos de la ciudad romana se conocen desde antiguo, siendo citada y recogida en las diferentes historias y escritos, desde el siglo XVI, y muy especialmente a partir de 1788, cuando Juan Loperráez, proporcionó un plano de las ruinas. La posibilidad de una ubicación distinta de la ciudad celtibérica y la romana fue planteada, a principios del pasado siglo, por Ignacio Calvo (1916). No obstante, Taracena (1931-32), que llevó a cabo importantes excavaciones en la ciudad, pensó que la ciudad indígena estaba en el mismo lugar que la romana.

No obstante, investigadores posteriores como Osaba (1964) se refieren a la existencia en el cerro del Alto del Cuerno de un castro con restos de muros y cerámicas ibéricas y romanas, lo que fue asumido más tarde por Palol (1969), ya que en las excavaciones de la ciudad romana no se encontraban restos anteriores a Tiberio. Las evidencias no se limitan solamente a este cerro, sino que se extienden de manera discontinua un amplio espacio delimitado por el río Arandilla y sus afluentes Espeja y Dor, en el que destacan algunos resaltes amesetados que dan nombre al conjunto, Los Castrillos, con una altura de $1021 \mathrm{~m}$ sobre el nivel del mar y unos $120 \mathrm{~m}$ sobre el valle, que le proporciona buenas características defensivas y de control del territorio. En algunos de estos cerros, que configuran una extensión de unas 60 hectáreas, se aprecian grandes tramos de muros defensivos, que formarían parte de una acrópolis. El escaso conocimiento de este sitio no permite tener una referencia para el momento inicial y final de su ocupación, pero por la abundancia de cerámica de plena etapa celtibérica, se deduce que el momento álgido correspondería a partir del siglo III a.C. y que sería destruida y abandonada tras las Guerras Sertorianas (Sacristán 1994: 135 y 2005: 183).

\subsection{Sekobirikes}

Un problema diferente plantea la ubicación de esta ceca, identificada con Segobriga, que Schulten y Bosch Gimpera situaron a principios de s. XX en el cerro de Cabeza del Griego, en Saelices (Cuenca), donde se ubica la Segobriga romana. Pero, para distintos autores, las citas de Frontino y Estrabón, sobre la ciudad de época celtibérica, no parecían corresponder con la de Cuenca, a lo que se unía la falta de restos arqueológicos en el cerro de Cabeza del Griego, ya que los más antiguos son de mediados del s. I a.C. A esto hay que añadir el estudio realizado por García y Bellido (1994: 245) sobre la circulación de las monedas celtibéricas, con el nombre de Sekobirikes, que muestra como éstas están mejor representadas en la zona del Alto Duero, siendo escasas en el marco conquense y casi ausentes en Segobriga, lo que ha llevado a situar la Segobriga celtibérica por esta zona, habiéndose propuesto el yacimiento de Pinilla Transmonte, Burgos (18 ha, con buenas defensas y una rica necrópolis), justamente en el límite territorial entre arévacos y vacceos (Burillo 1998: 193,316; Sacristán 2005: 190). Por lo que el yacimiento del Cabezo del Griego correspondería ya a una fundación imperial romana, realizada con celtíberos de aquella zona, a mediados del siglo I a.C. (Abascal et al. 1999)

Por otro lado, el dato aportado por la tésera de hospitalidad con el nombre de Sekobirikea (Almagro-Gorbea 2003: 211), indica la existencia de este nombre en la zona conquense, por lo que se deduce que al menos podría haber dos Segobrigas celtibéricas, una en la zona del Duero, que acuñó moneda, y otra en la zona de Cuenca, que no acuñaría moneda y que no estaría en Cabeza del Griego, donde se asentó la romana.

\subsection{Contrebia Leukade}

Las primeras noticias sobre estas ruinas, situadas en Inestrillas (Aguilar del Río Alhama, La Rioja), fueron proporcionadas por Traggia (1792). Serán más abundantes las referencias a lo largo del s. XVIII y XIX; pero fue Blas 
Taracena (1926), a principios del siglo XX, quien abordó el tema de una manera científica, identificando estos restos con la ciudad celtibérica de Contrebia Leukade, a partir de la cita de Tito Livio y realizando excavaciones en 1934 y 1935, que le permitieron concretar sus fases de ocupación, así como descubrir su sistema defensivo y la ordenación del espacio interior. Pero los trabajos realizados a lo largo de estos años han aportados nuevos datos para el conocimiento de las diferentes fases de la ciudad y especialmente para un mejor conocimiento de la ocupación celtibérica (Hernández et al. 2007).

\subsubsection{Urbanismo}

La ciudad, con una extensión de unas 12 ha, se asienta entre dos cerros de diferente altura, separados por una vaguada (al igual que otras ciudades, como Uxama). La zona mejor defendida es el lado más occidental, que cae en brusca pendiente sobre el cauce del río Alhama, siendo la zona más accesible por donde desagua la vaguada. La ciudad tendría su origen hacia la segunda mitad del siglo IV a. C., cuando se amplia el poblado inicial, al parecer por sinecismo de la población de otros dos poblados próximos, que desaparecen, a lo que res-

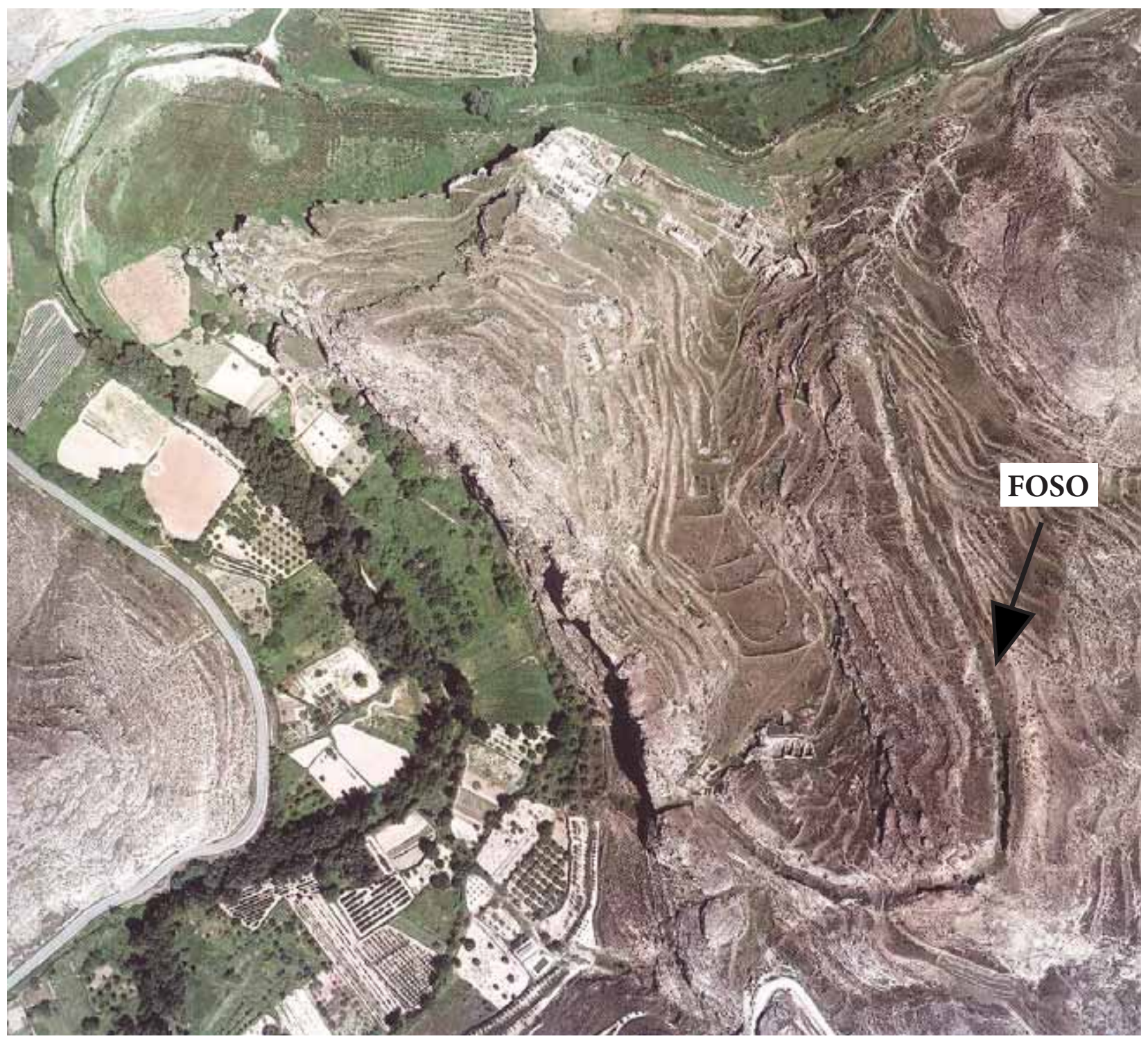

Figura 11.- Vista aérea de Contrebia Leukade. Se puede apreciar el imponente foso defensivo (Hernández et al. 2007). 
pondería su nombre (Hernández et al. 2007). El caserío de la ciudad se ajusta a las abruptas pendientes, disponiendo las casas alineadas respecto a calles (su anchura varía entre 1,80 y $2 \mathrm{~m}$ ), que siguen las curvas de nivel que configuran las pendientes de los cerros, pero también hay pasillos de comunicación, a veces con escaleras, que comunican transversalmente y en pendiente las calles de trazado horizontal. Las calles están excavadas en la roca de base, lo que ha facilitado su conservación y en ellas se pueden apreciar las huellas de rodadas de carros. Para evacuar las aguas de lluvia la ciudad contaba con un sistema de canalizaciones o desagües, de sección cuadrada, de unos $50 \mathrm{~cm}$ de anchura, que por lo general están abiertos en la roca natural, cortando transversalmente las alineaciones de casas y de calles, dirigiéndose hacia el río y atravesando la muralla.

\subsubsection{Sistema defensivo}

Para reforzar su defensa se construye una muralla con un gran foso (Fig. 11). Los restos más antiguos de la muralla celtibérica, ya que fue anulada en gran medida por la ciudad romana construida encima, se conservan en el extremo oriental, en el punto más elevado del conjunto arqueológico, no obstante, se puede seguir en gran parte su trazado por los entalles realizados en la roca para asegurar su asiento. En la zona norte, más desprovista de defensas naturales, la muralla para conseguir una mayor efectividad defensiva, adoptaba un sistema quebrado, disponiendo diferentes tramos oblicuos entre sí, en forma de cremallera. Esta defensa se vio reforzada por un gran foso en el lado oriental de la ciudad, que está excavado en la roca y alcanza una longitud próxima a los $700 \mathrm{~m}$, con una anchura y profundidad en torno a los $8 \mathrm{~m}$. La piedra obtenida en esta ingente obra se utilizó en la construcción de la muralla. Se conocen como refuerzo torres rectangulares, de las que se han hallado cuatro, que no se proyectan hacia el exterior de la muralla, sino hacia el interior. Están separadas entre sí unos veinte metros y tienen gran tamaño, ya que en algún caso superan los $70 \mathrm{~m}$ cuadrados, compartimentadas por un muro central en dos estancias, comunicadas por puertas, que nos remiten al mundo mediterráneo e ibérico.

\subsubsection{Espacios domésticos:}

Las casas son de planta rectangular, por lo general compartimentadas en varias dependencias dispuestas longitudinalmente: un vestíbulo que se utilizaba para actividades artesanales y domésticas, una habitación principal en la que se situaba el hogar, ligeramente elevado sobre el suelo, y un almacén, a veces de grandes dimensiones, excavado frecuentemente en la roca natural. La conservación de parte importante del alzado de los muros excavados en la roca, así como de los mechinales donde encajaban las vigas, permite reconocer la existencia de varias plantas en algunas casas. Los suelos eran de tierra apisonada. En el vestíbulo o en la habitación principal, suele haber uno o dos depósitos excavados en la roca y revocados de yeso, que se cubrían con una tapa de madera.

\subsubsection{Abastecimiento de agua}

Se dotó la ciudad también de un sistema hidráulico para asegurar el abastecimiento de agua permanente, sin depender del exterior. Para ello realizaron dos túneles tallados en la roca, que permitían acceder desde el interior de la ciudad al nivel freático del río Alhama. Uno de estos accesos era un canal que comunicaba con la llamada cueva de Los Lagos, del que se conserva la entrada y los primeros metros de recorrido y otro, a través de un tramo abovedado con escaleras talladas en la roca, llevaba a un depósito, que era abastecido por un canal exterior que captaba el agua del río (Hernández et al. 2007).

\subsection{Arekoratas}

Esta ciudad no se menciona en las fuentes clásicas, pero existen frecuentes referencias a ella en los textos que conocemos en lengua celtibérica; así el bronce de Luzaga alude a sus habitantes, ArekoraTikuBos, y una tésera de hospitalidad inicia su texto con AreKoraTika: Kar, o tésera de la ciudad de Arecorata. Esta ciudad acuñó monedas con las leyendas Areicoraticos y podemos parangonar sus importantes emisiones con las de SeKeiza (Segeda, en el Pueyo de Mara, Zaragoza). Ambas ciudades, aparecen 
citadas en la primera mitad del siglo II a.C. y se convierten en las dos primeras cecas celtibéricas que acuñan moneda. Algunas monedas de AreKoraTa, al igual que de SeKeiza, han aparecido en los campamentos numantinos, ratificando de esta manera su cronología. Destaca su compleja serie monetal (acuña en plata: denarios $\mathrm{y}$, en bronce, toda la serie de divisores conocidos), y prolonga su emisión al menos hasta finales del siglo II e inicios del siglo I a.C. (Domínguez 1988; Burillo 1998: 252-254; Otero 1993: 2007).

Trabajos recientes han proporcionado la localización de una tésera de hospitalidad con forma de animal con letrero ibérico: ToUTiKa. Se trataría en este caso de un nombre común y, en particular, es un sustantivo abstracto con el sentido de 'ciudadanía'. O sea que quien llevaba consigo la tésera iba a tener el mismo status de cualquier ciudadano de Arekorata, lo que ha permitido precisar, junto con los hallazgos de prospección realizados, la situación de estaciudad por debajo de la romana, Augustobriga (Jimeno et al. 2010: 291), citada por Ptolomeo entre los pelendones y después como una de las mansiones por las que pasaba la vía XXVII del Itinerario de Antonino La última cita sobre la ciudad corresponde al Anónimo de Ravena (siglo VII). Saavedra identificó esta ciudad romana con los restos arqueológicos de Muro, a mediados del siglo XIX.

La ciudad se asienta en un amplio cerro de suaves pendientes, en el que se diferencia una zona más elevada, o acrópolis, donde se asentó el castillo medieval y el pueblo actual. Tiene una altura de $1.046 \mathrm{~m}$ sobre el nivel del mar y de 46 $\mathrm{m}$ sobre la llanada. La información sobre los restos arqueológicos, proporcionados por Saavedra (1981: 51), se refieren únicamente a la muralla relacionada con la ciudad romana, que tendría un perímetro de forma trapezoidal, de $3.077 \mathrm{~m}$ (del que conserva más o menos visibles 1.904 $\mathrm{m}$ ), abarcando una superficie de unas 49 ha. No podemos determinar en qué medida esta muralla se adaptó a la ciudad celtibérica anterior.

\subsection{Occilis}

Es citada por Apiano (Iber., 93), en relación con la campaña de Nobilior contra Numancia, en el año 153 a.C. y en la de Marcelo, el año 152 a.C., pero no volverá a ser nombrada posteriormente. La primera cita está relacionada con la huida de los segedenses de su ciudad para buscar refugio en Numancia, por lo que el camino más corto entre ambas ciudades es, sin duda alguna, por el puerto de la Bigornia (108 $\mathrm{km}$ frente a los 150-160 km por Medinaceli), por lo que sería a través de este recorrido por donde se debería de buscar los restos de esta ciudad. Fue situada por Schulten (1945: 61) en Medinaceli por homofonía ("nombre que parece sobrevivir en el de Medina-celi"), quizás recogiendo asociaciones ya hechas por autores anteriores (Rabal 1889: 398-399), para apoyar el itinerario que seguirían las legiones romanas para el acceso a Numancia, a lo largo de la ruta del Jalón, al inicio de las guerras celtibéricas. Pero no hay bases arqueológicas, ya que no se conocen restos celtibéricos en Medinaceli ni en el cerro próximo, la Villa Vieja, que se ha utilizado como alternativa (Mélida 1926; Borobio et al. 1992). Los restos hallados debajo de la actual Medinaceli corresponden a una ciudad de época imperial romana de la que no se conoce su nombre antiguo, tampoco la cita el Itinerario de Antonino, cuando se refiere a las mansiones de la vía XXV, que pasaría al pie del actual cerro de Medinaceli, ya que alude sólo a las ciudades de Arcobriga (Monreal de Ariza, Zaragoza), situada en el itinerario en una posición anterior a Medinaceli y Segontia (probable Sigüenza, Provincia de Guadalajara), que estaría en una posición posterior (Lostal, 1980: 201). Las crónicas árabes la denominan en un principio Medina Talmeida (Ciudad de la Mesa) y después Medina Salim (ciudad de Salim ibn Waramad), de donde procede su actual nombre, que fue quien estableció la capital de la Marca Media del Califato Omeya en Medinaceli, tras su traslado desde Toledo, en el siglo X (Sancho 1985).

\subsection{Voluce}

Esta ciudad se relaciona con la Veluca de Ptolomeo (Geog., II,3) atribuida a los pelendones y es citada como Voluce en el Itinerario de Antonino (siglo III) como mansión entre las ciudades de Uxama y Numancia. Taracena 
(1924-25), que excavó el yacimiento de Los Castejones (Calatañazor, Soria), se inclinó por relacionar estas ruinas con esta antigua ciudad por ser "las únicas próximas a la vía en el lugar donde debió estar Voluce", aunque se extraña de la poca extensión del asentamiento, en relación con las mansiones próximas de Uxama y Numancia.

Está situado en un cerro escarpado, de forma triangular, frontero a la actual Villa de Calatañazor, limitado al norte, este y oeste por el foso natural del río Milanos, que corre a unos $80 \mathrm{~m}$ por debajo de su cumbre, situada a $1.060 \mathrm{~m}$ sobre el nivel del mar. Su zona sur, que es la más accesible desde el páramo, está reforzada por una potente defensa, de $4,50 \mathrm{~m}$ de altura, alcanzando el derrumbe de su caída $18 \mathrm{~m}$ de espesor. Está realizada con sillarejo bien careado y regular. Se pueden apreciar los restos de una escalera, realizada en la propia muralla, que desciende desde el interior del recinto al exterior. Se puede pensar en un doble recinto defensivo, ya que a $24 \mathrm{~m}$ de esta muralla se halló otro lienzo paralelo al anterior. Los restos de adobe y grandes trozos de ladrillo con enlucido de barro, pegado al muro, fueron interpretados como restos de casas adosadas a la muralla. La revisión de los materiales de las excavaciones de Taracena, depositados en el Museo Numantino, ha permitido documentar dos momentos de ocupación: uno del siglo II a.C. y otro tradorromano de los siglos IV-V d. C., lo que cuestiona su relación con Voluce, citada por el Itinerario de Antonino, en el siglo III (Pascual 1991).

Como se puede apreciar, por lo planteado anteriormente, el problema es relacionar el nombre de estas ciudades con un yacimiento arqueológico o lugar concreto. A veces, las referencias de las fuentes escritas dan pistas sobre el territorio aproximado, siendo más fácil situar aquellas que perviven en época imperial romana y aparecen citadas en relación a los itinerarios o vías de comunicación. También las emisiones de monedas y el análisis de la distribución de las mismas (mayor concentración del monetario en torno del centro emisor) permiten determinar aproximadamente su ubicación en un territorio determinado $\mathrm{y}$, a veces, en un yacimiento concreto (Burillo 1995). Por otro lado conocemos

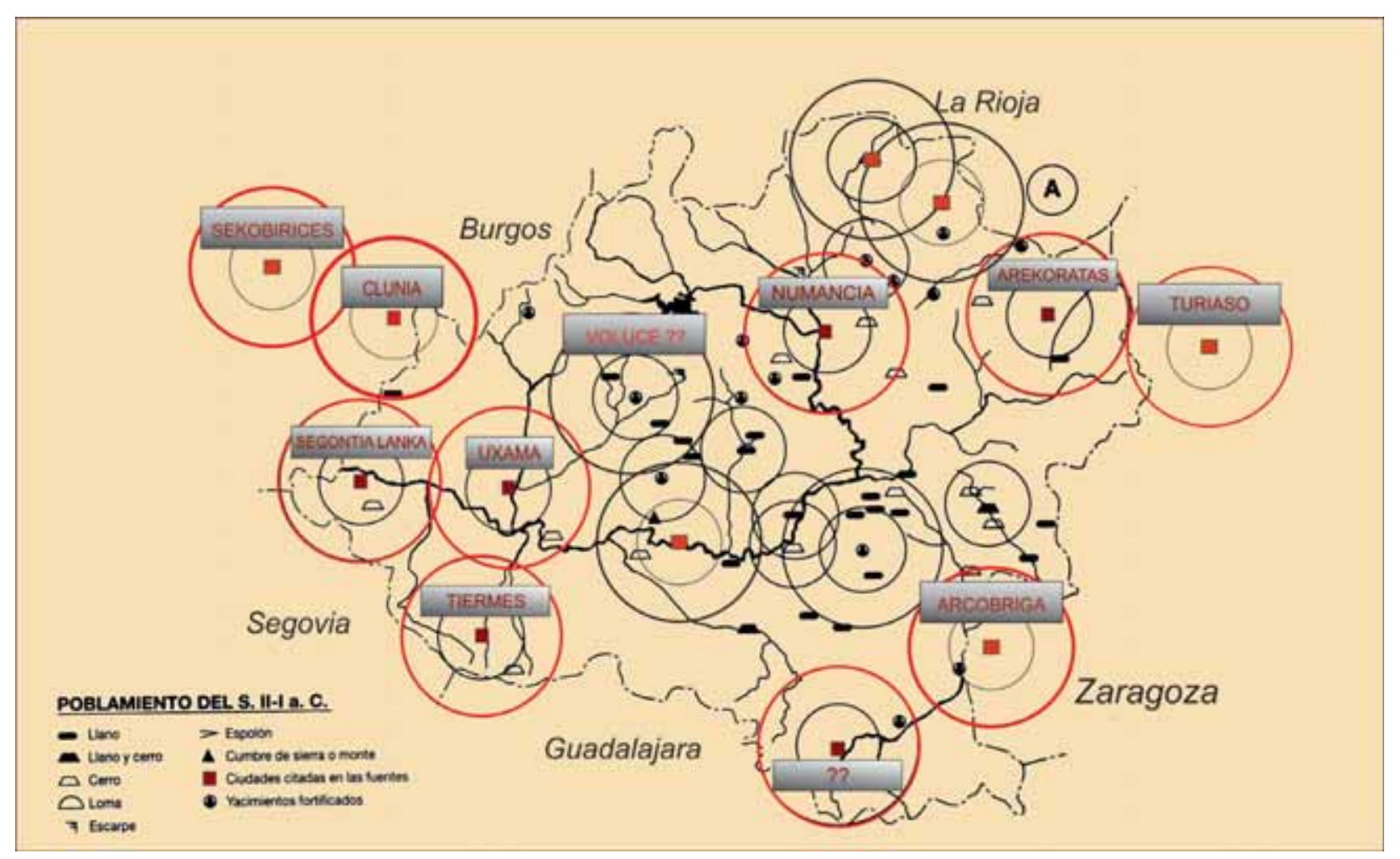

Figura 12.- Las ciudades localizadas de la Celtiberia Ulterior con sus territorios hipotéticos. 
yacimientos extensos, es decir ciudades, que no es posible relacionar con las citadas por los textos romanos o conocidas a través de la epigrafía.

\section{Ordenación del poblamiento: ciudades estado y territorios}

\subsection{Territorios y ciudades}

Las ciudades celtibéricas y sus territorios estructuraban y jerarquizaban el paisaje en función de su importancia (Fig. 12), ya que todas no tenían la misma categoría, reflejándose su rango, por lo general, en función de su mayor extensión, disminución en número y separación entre ellas, concediéndoles la máxima jerarquía, con las reservas apuntadas más arriba, a las que emiten moneda de plata, menor rango a las que lo hacen en bronce y el más bajo a las que no acuñan. En la zona soriana, en el siglo II a. C., solamente fabrican moneda las ciudades de Arekoratas, de plata y bronce (con las leyendas de Arekorata, Arekoratas o Arekoratikos) desde mediados del siglo II a.C. hasta finales al menos de este siglo (junto con Secaiza son las dos primeras cecas celtibéricas en acuñar moneda) y Uxama Argaela, que emitirá moneda de bronce, a fines del siglo II a.C., con la leyenda Arkailikos (menos atribuible es la ceca de Usamus a esta ciudad, puesta en duda por de Hoz 1986: 63); Clunia acuñará sólo numario de bronce más tardíamente (a mediados del siglo I a. C.) y Segontia Lanka, que se fundará después de la destrucción de Numancia, 133 a.C., emitirá moneda de plata y bronce en el siglo I a.C., ya que otras cecas propuestas no ofrecen ninguna seguridad en su localización (Burillo 1998: 252).

Las fuentes literarias se hicieron eco de la jerarquización del poblamiento, distinguiendo diversas categorías como ciudades (denominadas "polis", "urbs", “civitates" y, más raramente, "oppida", sin que pueda establecerse diferenciación entre estos términos), grandes aldeas, “castellae" y pequeños asentamientos (Schulten 1945; Taracena 1954).

Las ciudades, como se ha indicado anteriormente, ocupan altozanos de bastante altura y, a veces de relieve escabroso (Termes, Uxama, Contrebia Leukade), emergiendo generalmente sobre los valles de los ríos y tierras propicias

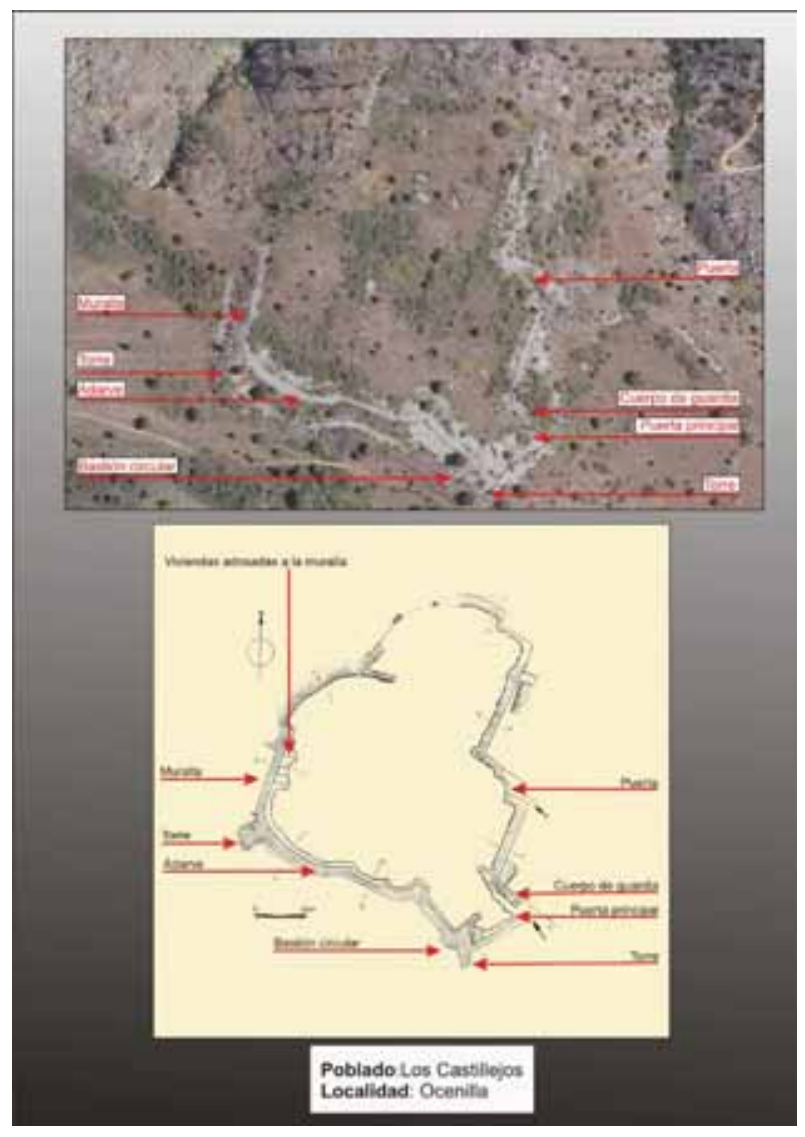

Figura 13.- Fotografía aérea y dibujo (Taracena 1941) de El Castillo de Ocenilla.

para la agricultura. Su caserío se adapta a la topografía de terreno, bien sea llano o escalonado, estando rodeado de muralla, su apretada edificación está más o menos ordenada por calles y carecen de plazas o lugares abiertos, así como de una arquitectura monumental, aunque hay que valorar que, por lo general, las ciudades celtibéricas han sido arrasadas y alteradas por la construcción de ciudades romanas encima. La superficie de estos núcleos en época celtibérica oscila entre 7 y 15 hectáreas, pudiendo llegar o superar en un momento avanzado las 20 hectáreas (Almagro-Gorbea 1994; Lorrio 1997). Cuando la ciudad crece, amplía o construye una nueva muralla, como es el caso de Segeda (Burillo 2006: 203) o bien amplía el muro por aquella zona donde la menor pendiente de la ladera del cerro lo permite, como es el caso de Numancia (Jimeno et al. 2002).

En las zonas bajas del Alto Duero se conocen una serie de poblados de mediano tamaño con cierta entidad (entre 3 y 4 ha), situados en cerros o lugares elevados, en torno a los cuales se jerarquiza el territorio, como los Villares de 
Ventosa de la Sierra. En las zona cerealista de la tierra de Almazán optan por pequeñas elevaciones en las campiñas, destacando el cerro de San Cristóbal (entre Soliedra y Escobosa), con amplísimo recinto murado de más de dos metros de ancho, del que solamente queda la base, que sería reocupado en época romana; así como la ciudad que la empresa Areco está excavando en Ciadueña; también se conocen en lugar llano, como Los Chopazos (Revilla 1985). En la zona central se reparten el control tres núcleos poblacionales de menor rango o grandes aldeas, como son El Altillo de Las Viñas de Ventosa de Fuentepinilla, Castilterreño de Izana y Los Castejones de Calatañazor (Tarcena, 1941: 46; Pascual, 1991: 31), así como otros núcleos más pequeños, de menos de una hectárea (Jimeno y Arlegui 1995). Un proceso similar se ha detectado en el Noreste de Guadalajara, donde destaca por su dimensión urbana el yacimiento de Los Rodiles de Cubillejo; en torno a éste se conocen otros menores, relacionados con actividades agropecuarias o artesanales (Burillo 1998; Arenas, 1999; Cerdeño et al. 2008).

Finalmente, los "castillos" o torres de reducida dimensión y alto valor estratégico (entre 1 y 2 ha), que como ya fueran definidos por Taracena (1954: 224-246), no solo ocupan altozanos o cumbres naturalmente defendidos, sino parajes que dominan zonas extensas y defienden o obstaculizan pasos que debieron ser rutas de comunicación y son en general más reducidos, de muralla más robusta y menos densa edificación interna. En orden a emplazamiento y distribución interna, los castillos difieren de la ciudad y la aldea, que se asemejan entre sí, pero, sin duda alguna, complementaron su acción con las ciudades y otros poblados; pero su concepción, formando alineaciones de control y dominio, responden a una estrategia de conjunto. En muchos casos se recuperan antiguos hábitat de tipo castreño, como La Coronilla, Las Arribillas y El Castillejo de Anquela, en la zona del Alto Tajo.; Golmayo, Ontalvilla, Ocenilla (Fig. 13) y Cabrejas sobre los pasos naturales de la recta de la Sierra de Frentes; El Pico de Cabrejas del Pinar, Los Castejones de Calatañazor y El Portillo de Andaluz marcan un camino natural Norte-Sur, con plena vigencia en la Edad Media; así mismo, el paso del Alto Jalón desde el Ebro a la Meseta está controlado por los castillos de Castilmontan (Somaen, Soria) y El Castillo de Santa María de Huerta, en la linde entre Aragón y Castilla. En Tierras Altas, que ocupan el reborde montañoso del sistema ibérico soriano, a caballo del valle del Ebro y el Duero, destacan El Castellar de San Felices, en las gargantas del río Alhama, Torretarranclo, único paso en la divisoria de los valles de San Pedro Manrique y Fuentes de Magaña; Sarnago y El Castillo de Taniñe, que dominan el valle entre Huerteles y San Pedro, cerrando el paso al de Yangüas (Jimeno y Arlegui 1995; Alfaro 2005).

En la zona de contacto entre el Alto y el Medio Duero, zona suroeste de la provincia de Soria, la distribución de los asentamientos y sus tamaños parece indicar una cierta ordenación del territorio similar al Alto Duero, mostrando concentraciones en torno a aquellos núcleos de referencia, como se observa en el territorio del actual San Esteban de Gormaz, en relación al yacimiento de Las Veletas, con 5 asentamientos, en un radio de siete kilómetros; otra en la zona de Vildé y Gormaz, con 3 yacimiento y 3 necrópolis, en un radio de seis kilómetros, y la zona de Segontia Lanca (La Cuesta del Moro de Langa de Duero) que, aunque de un momento posterior, alterna el control de la zona con otro de gran extensión como es El Castro de Valdanzo, con 10 yacimientos en un radio inferior a tres kilómetros, situados en zona límite con los vacceos, acusan ciertas peculiaridades en el tipo de hábitat $\mathrm{y}$ en algunos aspectos socioeconómicos y tecnológicos, característicos de una zona fronteriza (Heras 2000: 222).

Otra zona colindante con los vacceos, sería la que nuclearizaría Clunia (Quintanarraya, Burgos), en el área suroriental de la cuenca media del Duero, junto al borde de la vertiente occidental del Sistema Ibérico. La ciudad prerromana se debió situar en Los Castrillos, fronteros al cerro Alto de Castro, donde se situará posteriormente la ciudad romana, ambos separados por el cauce del río Arandilla. En relación con la Clunia prerromana destacan en su entorno algunos yacimientos situados en el centro de la cuenca del río Duero, como Solarana (entre 11 y 13 ha), Pinilla de Trasmonte (donde se quiere situar la ceca de Sekobirikes) y Arauzo de la Torre, que representan una prolongación del territorio arévaco, separados por el Sistema Ibérico. Se trata de núcleos grandes, con distan- 
cias entre ellos en torno a $15 \mathrm{~km}$, características que los asemejan a los de la región vaccea, en el Duero Medio, diferenciándolos del modelo de poblamiento arévaco, en la provincia de Soria, donde los grandes oppida centralizan territorios en otros asentamientos menores, en un sistema jerarquizado, lo que podría plantear problemas de delimitación entre ambos grupos, pero es posible que en esta zona limítrofe se extendiera un territorio deshabitado, que parece un fenómeno típico de algunas fronteras, como lo demuestran la presencia de cerámicas de estilo numantino (jarras decoradas con prótomos de caballo) de la necrópolis de Pinilla (Sacristán 1994: 144-145)

Aunque la función urbana de un núcleo de población no depende únicamente de su mayor tamaño, sí hay que tener este referente en cuenta para la diferenciación de ciudades en el territorio celtibérico, destacándose en rango y monumentalidad de los asentamientos rurales dependientes (Almagro-Gorbea 1994; Burillo 1998). A la hora de valorar la superficie ocupada por las ciudades a lo largo de su evolución histórica, nos encontramos con la dificultad de que algunas continúan siendo las mismas en época romana y, por tanto, el cálculo de sus dimensiones reales queda camuflado por el recinto romano, caso de Numancia, o sencillamente como Termes y Uxama que amplían su perímetro o planean la ciudad en la zona baja del antiguo cerro, más acorde con los planteamientos romanos de este momento (Jimeno 2000).

La documentación escrita y arqueológica presenta las ciudades como verdaderos centros organizadores, administrativos y políticos de sus territorios, cuya cabeza visible es el propio centro urbano, el oppidum (Beltrán 1987; Burillo 1998). No se entiende la ciudad sin su territorio, así lo reflejan los textos cuando se refieren a la conquista de Complega, en el 179 a. C., que indican que se sometieron con su territorio, o cuando Escipión toma Numancia, que dio la ciudad y su territorio a los indígenas que le habían ayudado a conquistarla, o en el caso de la destrucción de Colenda, en el 98 a.C., que se ofrece la entrega de sus tierras a los habitantes de una ciudad próxima (Apiano, Iber., 98, 99-100).

La importancia de las ciudades, queda reflejada en el hecho de que son ellas las que tratan directamente con Roma, siendo recibidas independientemente, y las que firman los acuerdos, aproximándose a la imagen que tenemos de ciudad-estado. La estructura social basada en las relaciones parentales de igualdad tendrá que acomodarse a las nuevas formas de dependencia que terminará imponiendo la estructura urbana. Será ahora la ciudad el referente primario de identidad. Fuera de sus fronteras el ciudadano carece absolutamente de derechos, no es nadie, de ahí los pactos de hospitalidad que se inscriben en las téseras, reflejando acuerdos mutuos que se establecían entre individuos de diferente origen, entre un particular y una ciudad o bien entre dos ciudades e incluso como se indica en la tésera con forma de lechón de Uxama Argaela, a la que hemos aludido anteriormente, la ciudad concede hospitalidad a "los extranjeros que viven sobre el Duero"; como se observa también en el bronce de Peralejo de los Escuderos (Soria), aunque ya de época imperial romana (s. II d. C.), relacionada con la ciudad celtibero-romana de Termes, se indica que "el Senado y el Pueblo Termestino concedió a los Dercinoassedenses, aldeanos de los clunienses, a sus hijos y descendientes que perteneciesen a Termes con el mismo derecho que los ciudadanos termestinos" (D'Ors 1951; Jimeno 1980: 160-161).

Las ciudades se verían obligadas a incorporar mayor número de contingentes no sólo para su defensa, sino también para cumplir con sus objetivos propios, ya que su surgimiento está estrechamente relacionado con el desarrollo de la producción y la expansión a un mercado más amplio, para cubrir las necesidades de una población en crecimiento. Esto conllevaría una asunción progresiva de la necesidad de especialistas a tiempo completo; así como el control del abastecimiento de materias primas y distribución de la producción. Es probable que esta especialización artesanal fuera progresiva e incluso que solamente algunos artesanos tuvieran esta condición, acorde con la mayor demanda del producto o productos fabricados, mientras que otras artesanías estarían destinadas al consumo o mercado local, lo que sería compatible con actividades domésticas, como la agricultura o la ganadería o incluso las relacionadas con lo militar (Galán 2005: 330). En el mundo celtibérico las artesanías más sobresalientes estarían relacionadas con los trabajos metalúrgicos tanto de herreros, como de orfebres y, en menor medida, los relacionados con la cerámica y el tejido. 


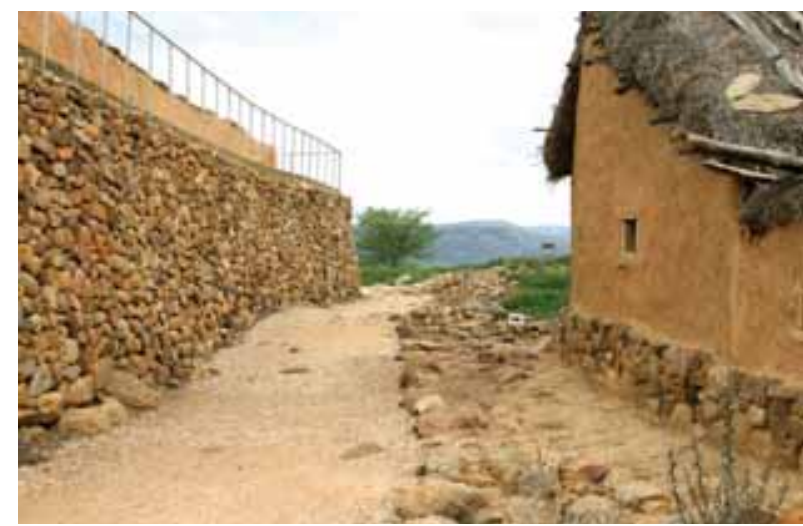

Figura 14.- Detalle urbanístico de Numancia, donde se aprecia la disposición de las casas separadas de la muralla por una calle de ronda.

Esto conllevaría núcleos urbanos con más calles y sistemas defensivos más evolucionados, cuya organización interna cada vez sería más compleja, con barrios diferenciados y especializados artesanalmente, algunos de estos trabajos, por sus características, debieron instalarse fuera de la ciudad.

Estas ciudades emergentes utilizarían sus resortes defensivos y sus enfrentamientos contra Roma para aumentar su prestigio e imponer su hegemonía en el entorno. La jerarquización del poblamiento se deduce también por las terminaciones de los nombres de algunas ciudades, que indicarían su influencia sobre una amplia región, e incluso algunas llegaron a controlar otras, limitándoles su autonomía, como parece deducirse de la existencia de una guarnición numantina de ocupación en la ciudad de Malia (Apiano, Iber., 77). A su vez, estas actitudes debieron ser aprovechadas por los intereses romanos, que procurarían beneficiar a unas sobre otras, lo que parece reflejarse en la regularidad de la distribución espacial, que muestran las ciudades que acuñan plata. Por otro lado, la vinculación de éstas al Sistema Ibérico y entorno inmediato estaría indicando la importancia que tubo este reborde montañoso como centro minero argentífero; más destacable, todavía si cabe, por la ausencia de este metal en el entorno inmediato de las cuencas del Ebro, Duero y Tajo (Burillo 1980 y 1989). En la zona soriana, solamente Arekoratas acuña moneda de plata y Uxama Argaela de bronce, ya que otras cecas propuestas no ofrecen ninguna seguridad en su propuesta de ubicación.

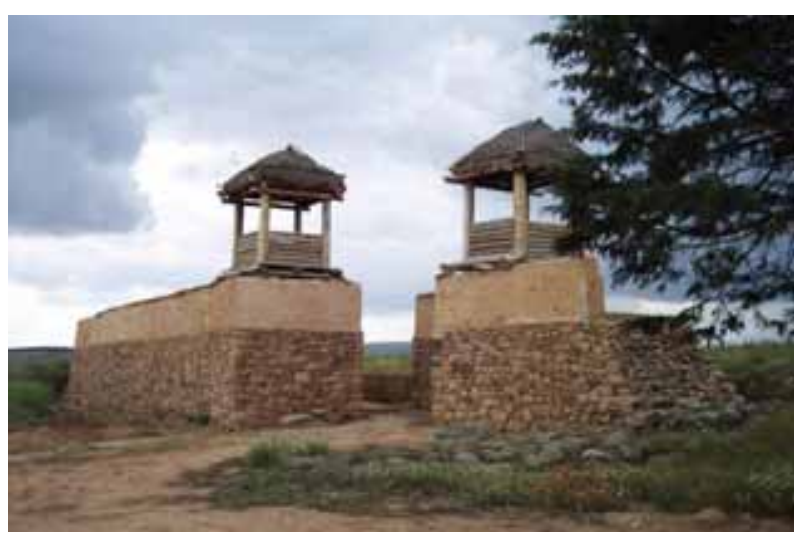

Figura 15.- Tramo reconstruido de la muralla de Numancia, con una de las puertas de acceso, protegida por dos torres de madera.

Las fronteras de estas ciudades-estado llegarían hasta donde éstas tuvieran capacidad de defender por sus propios medios, pudiendo exceder los límites naturales entre estas ciudadesestado (Castro y González 1989). La referencia de colindancias entre estos territorios está atestiguada sólo a través del trifinium de Fuentes de Ebro, en la provincia de Zaragoza (Beltrán 1957: 98). Es conocido que los estados vecinos son en general rivales, aunque sean afines en costumbres, lengua y religión; excepto en momentos de peligro común (Tibiletti 1978: 20). Lo que permite pensar que estas fronteras no debieron ser un hecho estático, ya que se conocen conflictos entre las distintas ciudades, como ocurre en los casos de Segeda con los titos y el de Malia con Numancia, comentados anteriormente.

Los territorios dependientes de las ciudades, como se ha apuntado anteriormente, estaban ocupados por todo un engranaje de asentamientos de pequeño tamaño o aldeas, poblados de mediano tamaño y castillos, con buenas defensas, ordenados estratégicamente para asegurar la producción, el control de sus zonas de influencia y vías de comunicación. En este sentido, hay que destacar que la conquista romana, realizada de este a oeste, contribuiría a potenciar las relaciones en esta dirección, impulsando los caminos que ponen directamente en comunicación el valle del Ebro con la Meseta, como son los del Jalón, el Queiles y el Alhama. Frente a este panorama expuesto tenemos el comentario que realiza Estrabón (Geographia, III, 4, 13), diciendo que "los pobladores de las aldeas son salvajes 


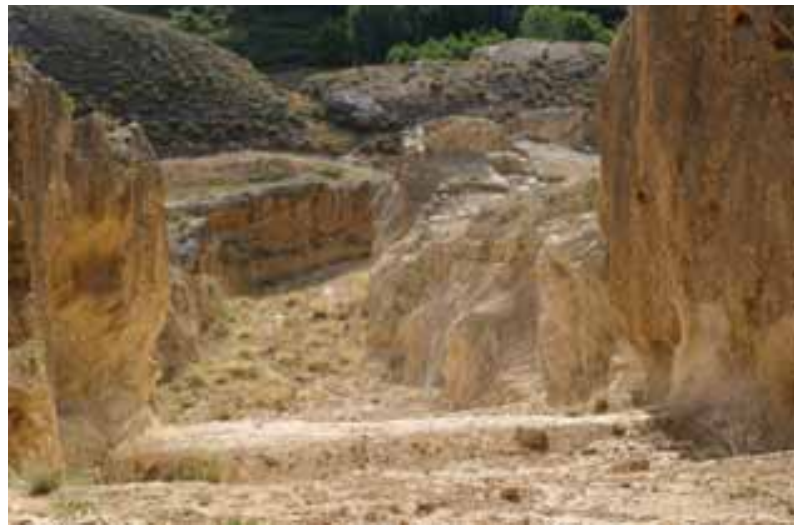

Figura 16.- Detalle del imponente foso de Contrebia Leukade (Hernández et al. 2007).

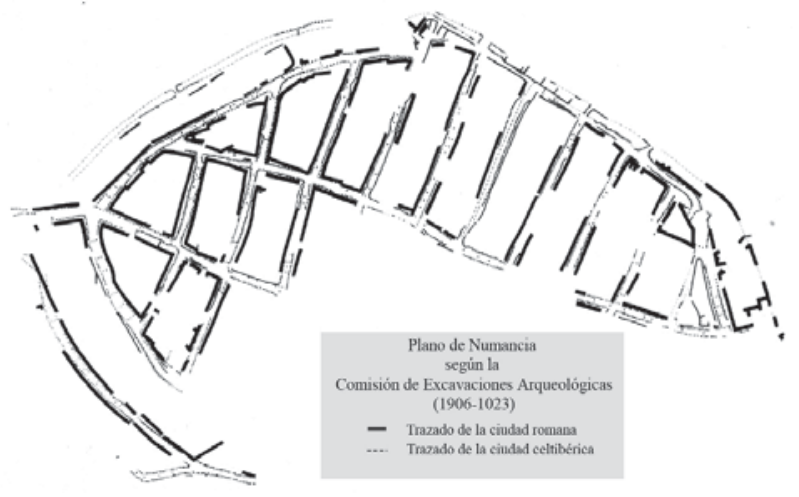

Figura 17.- Numancia: detalle de superposición urbanística de la ciudad romana sobre la celtibérica, según la Comisión de Excavaciones (1906-1923).

y así son también la mayoría de los iberos; las ciudades mismas no pueden ejercer su influjo civilizador cuando la mayor parte de la población habita los bosques y amenaza la tranquilidad de sus vecinos" y critica a Polibio (XI, 31, 6) por el comentario que hace sobre la destrucción de 300 ciudades en Celtiberia por parte de Tiberio Graco, por entender que da el nombre de ciudades a simples torres.

\subsection{Defensas y urbanismo}

En la estrategia de conjunto que ofrece el poblamiento, con la articulación de torres-castillos, aldeas y ciudades, para el control y dominio territorial, jugaron un papel importante los sistemas defensivos. Las líneas de muralla, aunque con alguna excepción, tienden ahora a regularizar las zonas sinuosas, imponiendo así un cier- to dominio de la fábrica arquitectónica sobre el recorte natural. En los textos clásicos tenemos referencias de la relación de estos recintos fortificados con el caserío; así, Tito Livio (XXI, 8, 5), refiriéndose a Sagunto, indica que se combatía "por entre las ruinas de las murallas y a poca distancia de las casas", lo que indica la existencia de intervallum entre las casas y la muralla; o la cita sobre Cartago Nova, donde "los asaltantes llegaron a incendiar las casas adosadas a las puertas y murallas de la ciudad". Un tramo de intervallum se conoce en Numancia (Fig. 14), pero es más usual que las casas estén adosadas a las murallas (Taracena 1954).

Los restos conservados de las murallas corresponden a las zonas bajas, que casi siempre eran de piedra; pero cuando algún yacimiento, como Castilmontán (Somaén, Soria) conserva una mayor altura, se han documentado en su parte superior recrecidos de adobes (Arlegui 1992). Hay que pensar, que algunas murallas desaparecidas, pudieron estar hechas con madera entrelazada y adobe o tapial, y pudieron arder, como nos relatan las fuentes en el caso de Pallantia, o desaparecer sin dejar rastro.

Las murallas pueden ser verticales o en talud y presentan una diversidad constructiva, desde

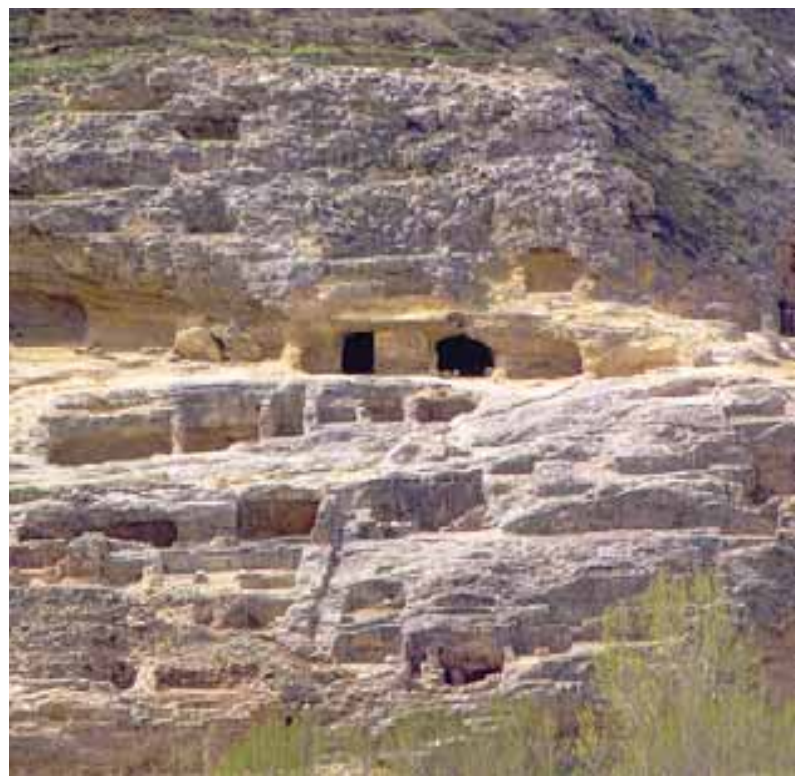

Figura 18.- Grupo de casas escalonadas en la ladera norte de Contrebia Leukade (Hernández et al. 2007). 
el empleo de sillares o grandes cantos rodados toscamente trabajados, dispuestos irregularmente, pasando por sillarejo bien careado, dispuesto en hiladas regulares, hasta el empleo de aparejo "ciclópeo". El grosor de estas defensas varía, por lo general, entre 2 y $4 \mathrm{~m}$ y para la altura se ha calculado unos $6 \mathrm{~m}$, correspondiendo la parte superior al parapeto, a veces de adobe, más estrecho que dejaba un camino de ronda o adarve para recorrer la muralla. Los rellenos de estos muros llevan frecuentemente paramentos internos de refuerzo. Se conocen también murallas dobles o zonas reforzadas con doble lienzo. El acceso a estos recintos se realiza por medio de puertas (Fig. 15) protegidas con dos lienzos acodados o con la disposición de doble muro; en las ciudades rupestres las puertas aparecen tajadas en la roca, disponiendo de doble portón, siendo menos frecuentes las puertas simples (Lorrio 1997: 71-93). La arquitectura, en este momento, aportará soluciones para una mejor defensa de los perímetros curvos a base de la construcción de lienzos acodados, que ejerzan un mejor control de las alineaciones. A veces, estas zonas acodadas sirven para instalar torres defensivas de forma cuadrangular, que, en ocasiones, alternan con bastiones circulares. Es frecuente el refuerzo de las murallas con fosos delanteros, como el impresionante de Contrebia LeuKade, excavado en la roca (Hernández 2007) (Fig. 16).

La estructuración interna de los asentamientos estará condicionada por el momento en el que surjan, la función que realicen y la población que aglutinen. No obstante, el urbanismo celtibérico se muestra como anexión de casas iguales, ordenadas en torno a calles o espacios, como ampliación del esquema inicial de los poblados de calle central. La densidad de habitantes por hectárea es bastante alta (208 h/ha en Numancia), en relación con otros contextos meseteños, como el occidental (Álvarez-Sanchís y Ruiz-Zapatero 2001: 71). La ocupación interna de los poblados y ciudades, es bastante densa, con viviendas ordenadas en manzanas y en torno a ejes de calles; a su vez, el espacio residencial dentro de los asentamientos ocupa más extensión que los espacios públicos.

Aunque no tenemos una amplia información sobre la urbanística de las ciudades celtibéri-
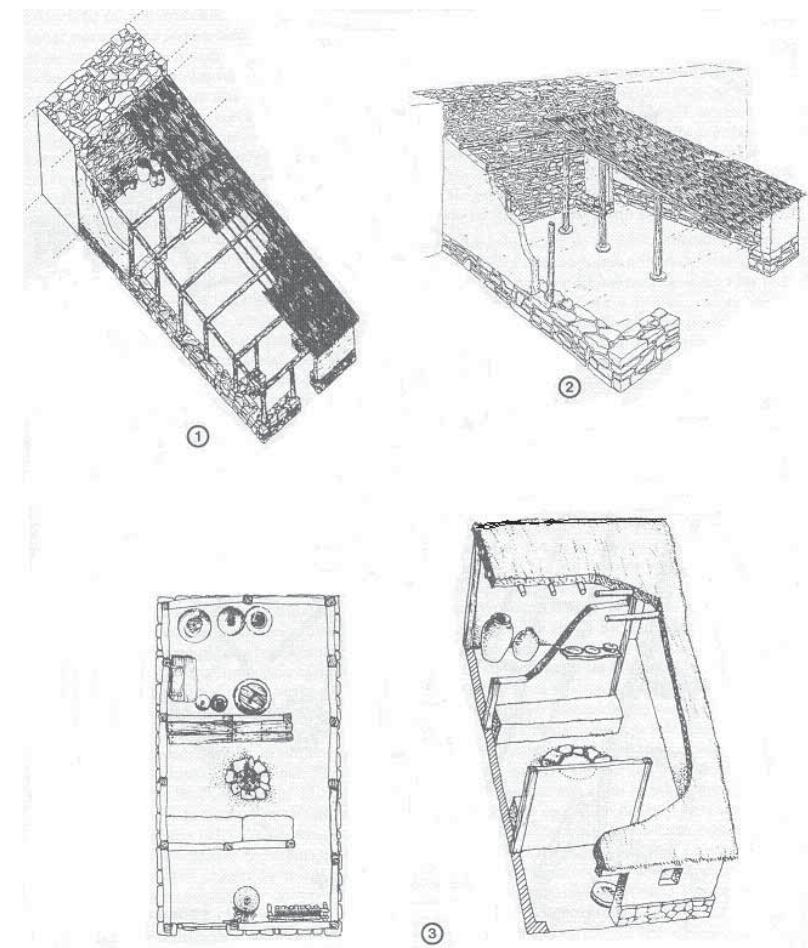

Figura 19.- Casas reconstruidas de los yacimientos del Ceremeño (1 y 2) y Castilmontán (3) (según Cerdeño 1995 y Arlegui 1990).

cas, es evidente que la aplicación del modelo se ve condicionado por la necesidad de adaptación a las características topográficas de los lugares donde se asientan las ciudades y a esto se unen frecuentemente las alteraciones sufridas por las ocupaciones posteriores (Fig. 17). No obstante, Numancia, que es la que ofrece una mayor superficie excavada, y está asentada en la plataforma superior de un amplio cerro, relativamente plano, permite ver su ordenación en retícula, teniendo como referencia dos calles centrales paralelas, orientadas de norte a sur, cortadas por otras diecisiete, que condicionan la ordenación de las casas en manzanas rectangulares. Este esquema, sin plazas ni lugares de encuentro, que es usual en la urbanística indígena, quizás mantenga cierta reminiscencia de los poblados de calle central, como referencia de espacio público. Este mismo plan presentan los poblados y ciudades vacceas del Duero Medio (véase cap. 6 de este volumen). En otras ciudades, a diferencia de Numancia, la urbanística está condicionada por la topografía del terreno, que conlleva, a veces, grandes desniveles. Así, Contrebia Leukade (Inestrillas-Aguilar 

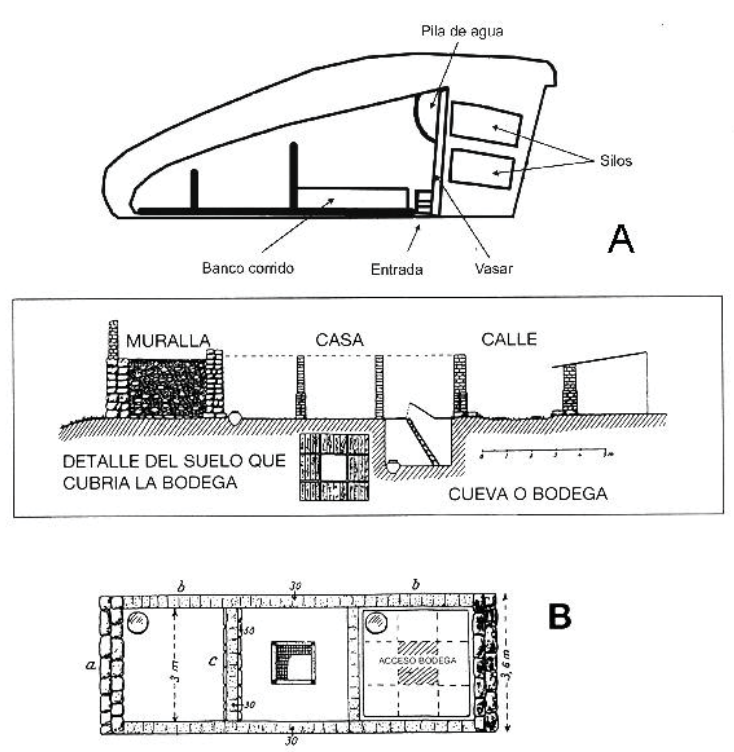

B

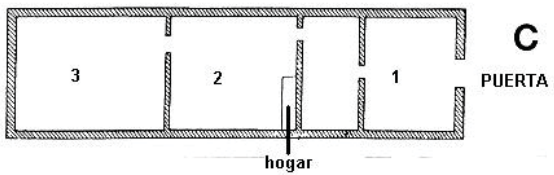

Figura 20.- Casas rectangulares tripartitas de Tiermes (A), excavada en la roca, y Numancia, en una de ellas (B) se puede apreciar la trampilla para acceder a la estancia subterránea o bodega.

del Río Alhama, La Rioja) se asienta sobre un espacio en pendiente, constituido por dos cerros y una vaguada intermedia, que establecía la relación entre ambos, acondicionados con terrazas a diferente altura, mediante el rebaje del manto natural y muros de contención; las casas, en parte excavadas en la roca, se alineaban en estas terrazas manteniendo medianiles comunes (Hernández 2007) (Fig. 18). Este panorama urbanístico se reproduce en otras ciudades como Arcobriga (Monreal de Ariza, Zaragoza), Uxama (Osma, Soria) o Termes (Montejo de Tiermes, Soria).

Algunas ciudades escogen para su asiento un cerro como acrópolis, extendiéndose también por la zona baja, configurando una planta casi rectangular, delimitada por muralla y foso, como Sekaisa y Contrebia BelaisKa (Botorrita, Zaragoza). En esta última el cerro estaba ocupado por un edificio singular columnado de potentes muros y, debajo, en una amplia zona aterrazada, viviendas con un trazado oblicuo de calles, con empedrados y aceras (Lorrio 1997; Burillo 1998; Beltrán 2005).

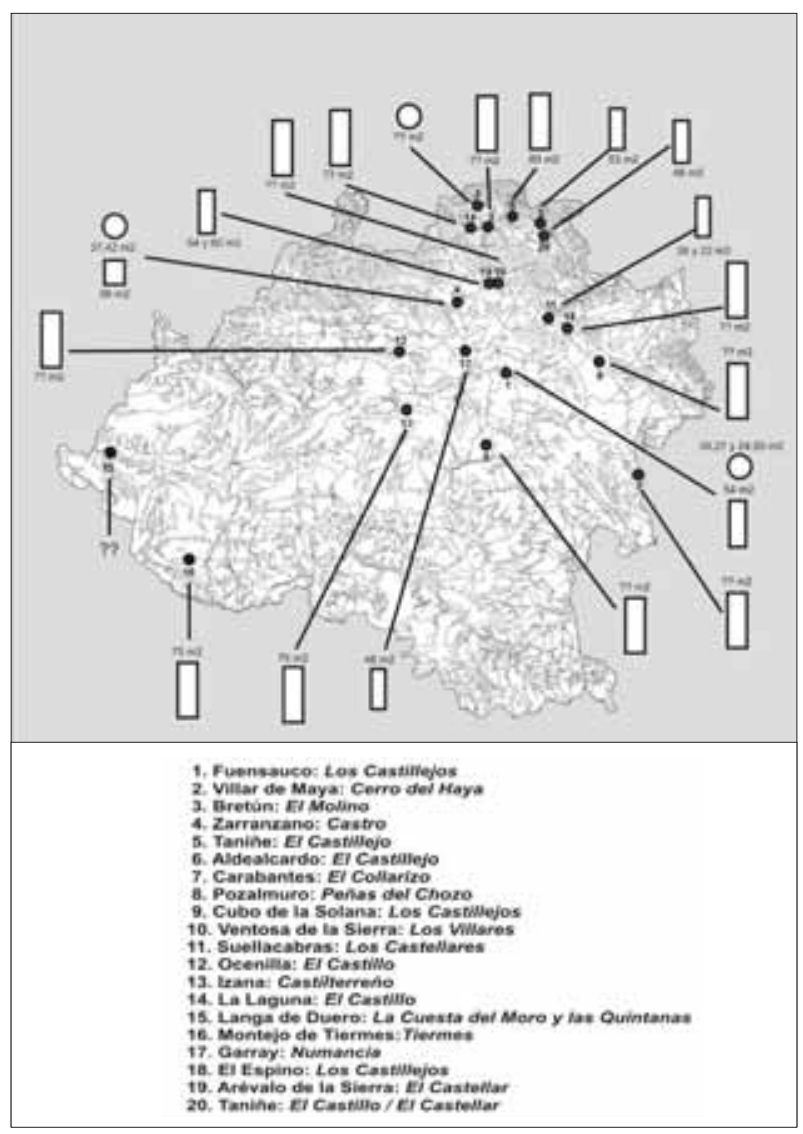

Figura 21a.- Plantas de las casas de algunos de los yacimientos con sus tipos y dimensiones.

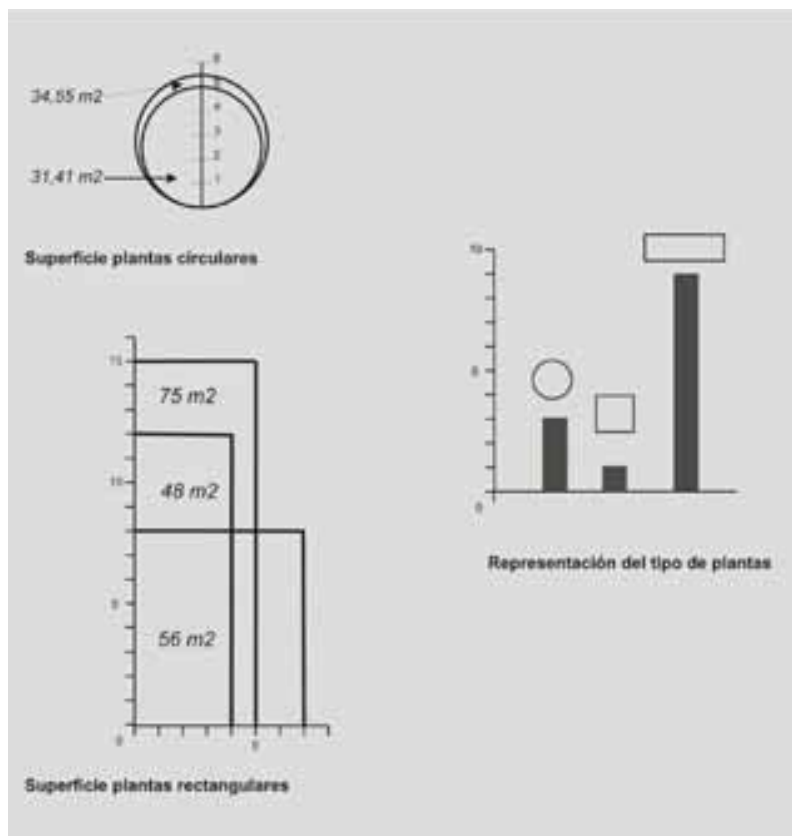

Figura 21b.- Representación de la frecuencia y tamaño de los diferentes espacios domésticos, en el Alto Duero, a lo largo de la cultura celtibérica. 
Serán los pequeños poblados los que mantendrán esquemas urbanísticos de la etapa anterior. Así, Los Castellares de Herrera de los Navarros (Zaragoza), que se destruyó en la transición del siglo III-II a.C., presenta un modelo de calle central, bien conocido desde el Bronce Final; a ambos lados se disponían unas 22 casas rectangulares, compartiendo muros medianiles y adosadas por su parte posterior a la muralla. Su caserío estaba protegido por un potente sistema defensivo con foso, doble muralla y torreón (Burillo, 1988). Es frecuente este modelo, aunque a veces con un espacio central mayor, en otros poblados pequeños, como Castilmontán (Somaén, Soria) o La Coronilla (Chera, Guadalajara). Algunos poblados presentan no sólo la alineación de casas pegadas a la muralla, si no también ordenadas en manzanas y separadas por calles en el centro, como en el Castillo de Arévalo de la Sierra, el Castillo de Taniñe, el Castilterreño de Izana, los Villares de Ventosa de la Sierra, en Soria (Taracena 1941).

\subsection{El espacio doméstico}

El espacio doméstico siempre posee una dimensión subjetiva y no puede ser entendido separado del mundo y la vida, siendo simbólicamente construido por los actores sociales. Los espacios son siempre creados, reproducidos y transformados, en relación con otros anteriormente construidos (Tilley 1994). Las casas son lugares donde se reproduce el orden social y cosmológico, mostrando también la construcción material de la desigualdad (González Rubial 2003).

A partir del siglo IV a. C., el espacio doméstico del interior de los poblados va a ser rígidamente distribuido en superficies igualitarias, con una alta estandarización de uso de estos espacios (Ortega 1999: 428), cada vez se acusa una mayor compartimentación y homogeneización de los módulos urbanísticos, que conllevan una mayor regularización de los espacios públicos y privados, disponiendo los hogares en la estancia central y bancos corridos en diferentes sitios (Jimeno y Arlegui 1995) (Fig. 19).

Los cambios en las relaciones sociales, comentados anteriormente, se reflejan en la nueva ordenación de los asentamientos y de los espacios habitacionales, vinculados también a una mayor diversificación económica agricultura-ganadería, relacionada con el abandono de muchos castros (en zonas de vocación ganadera) y la mayor ocupación de zonas de aprovechamiento agrícola, con el inicio de una jerarquización de los asentamientos, abarcando varios enclaves en territorios más amplios (Arenas 2007: 133; Jimeno 2009).

Se acondiciona ahora la planta de casa rectangular de la etapa anterior, compartimentándola en tres estancias, que serán las que se mantengan hasta el final del mundo celtibérico (Schulten 1945). Se construye en piedra, al menos el zócalo inferior o se embute el suelo en la roca o manto natural (Contrebia Leukade,
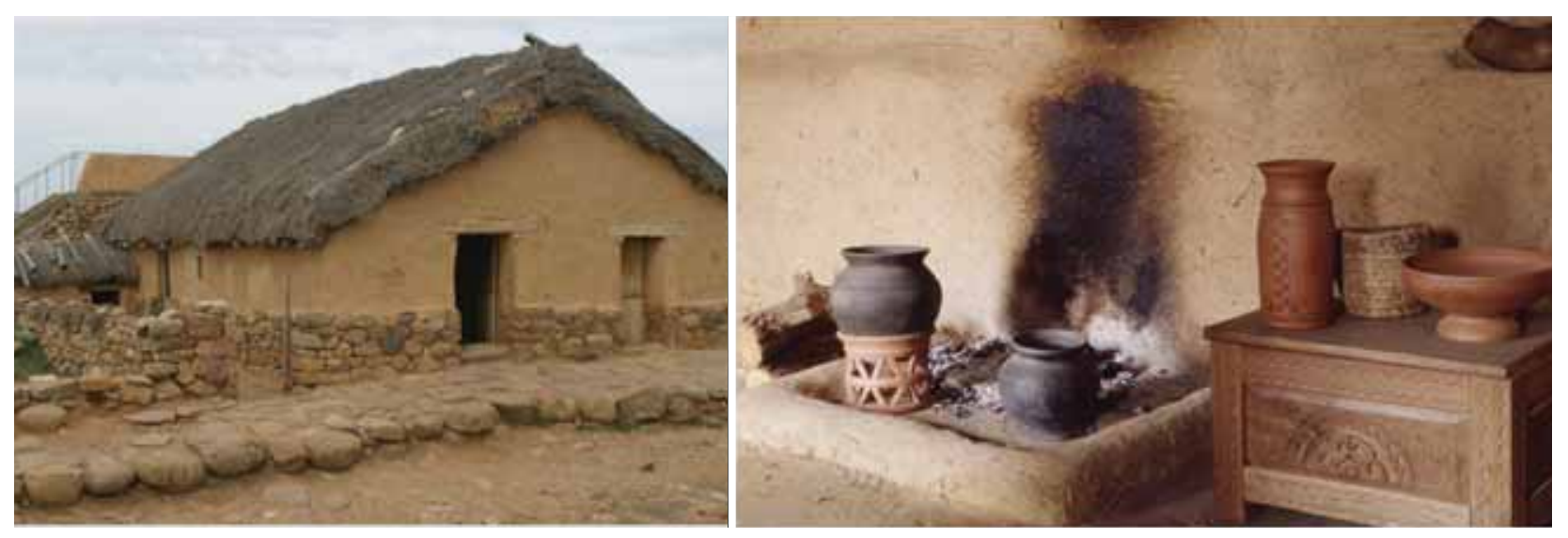

Figura 22.- Casa celtibérica reconstruida en Numancia, con el detalle del hogar interior. 


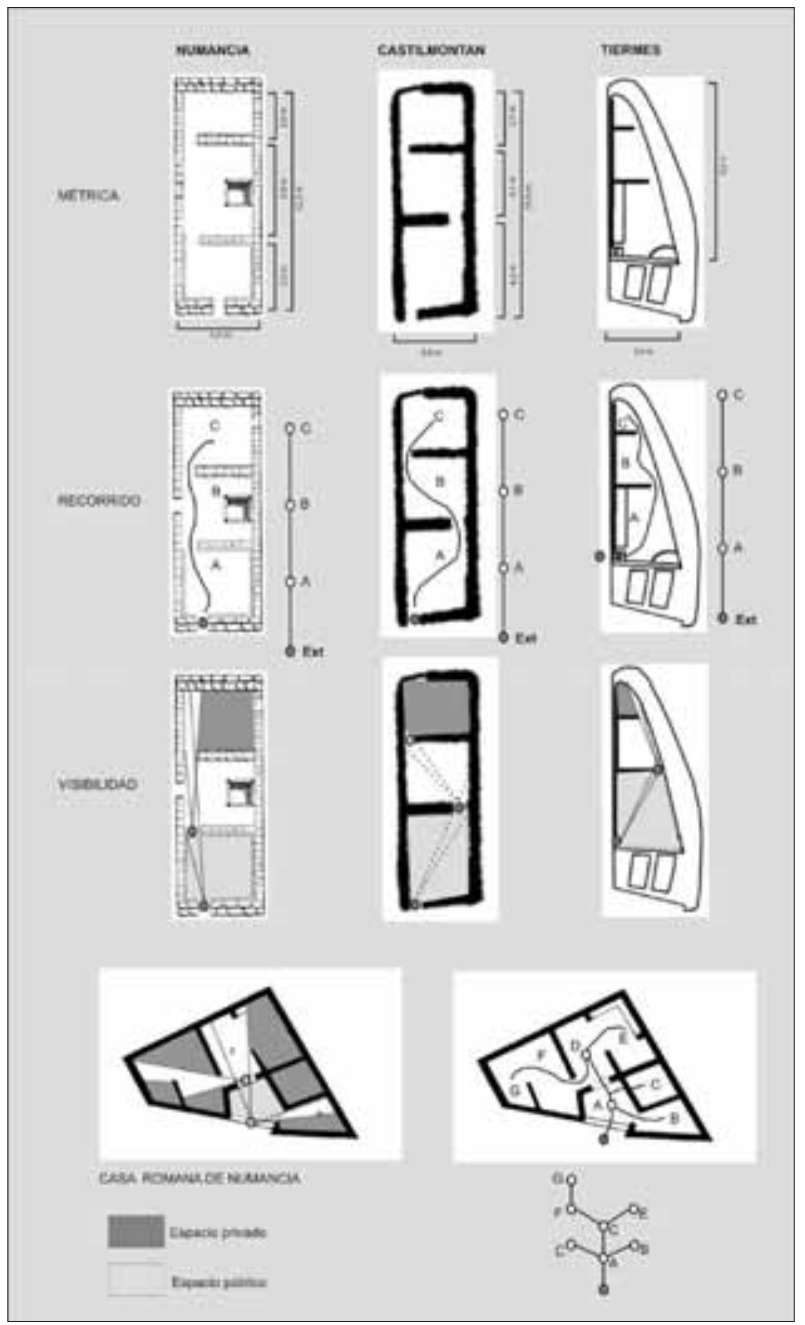

Figura 23.- Análisis métrico, de recorrido y visibilidad de las casas celtibéricas de Numancia, Castilmontán y Tiermes, reflejando su diferencia con una casa de época romana de Numancia.

Termes o Numancia) y se recrecen los muros con postes de madera, adobe o tapial, recubiertos con un manteado de barro y paja, rematados con techumbre vegetal sobre armazón de madera, como se observa ya en el nivel más moderno de El Ceremeño, en Herrería, Guadalajara (Cerdeño y Juez 2002: 44-56; Arenas 2007: 130), Castilmontán (Somaén, Soria), El Castillo de Taniñe, Ocenilla y Suellacabras (Soria); también en Ventosa de la Sierra (Soria), aunque con casas más irregulares y bastante grandes, alguna con estancia subterránea o bodega para conservar los alimentos, como se observa en Numancia y Termes (Taracena 1954: 240; Arlegui 1992) (Fig. 20). A veces este tipo de construcción queda reflejado sólo por grandes manchones rojizos de barro, que se observan en muchos de estos poblados: El Castillo de la
Laguna; El Castellar de Taniñe, Los Castillejos de Maya, El Castillejo de Buimanco, La Muela de Valloria y el Cerro del Haya de Villar de Maya, en Soria (Alfaro 2005: 255).

Es frecuente la presencia de casas yuxtapuestas adosadas a la muralla, como las siete halladas en el Castellar de Árevalo de la Sierra (Soria), aunque es posible que no todos los espacios rectangulares fueran casas, ya que éstas podrían ir intercaladas con corrales, como ocurre en El Palomar de Aragoncillo (Guadalajara) o en Numancia (Garray, Soria). También en Arévalo se documentan habitaciones de planta trapezoidal, de muros hechos con barro, empleando ladrillo mal cocido, lo que se observa también en Castilterreño de Izana (Soria), donde las viviendas son cuadrangulares, cimentadas sobre la roca, con muros de mampostería cogidos con barro, elevados con tapial, y presentando, las casas de la zona interna del poblado, estancias subterráneas de hasta $2,50 \mathrm{~m}$ de profundidad.

Se han podido estudiar algunos espacios domésticos en diez yacimientos de la zona del Alto Duero (Fig. 21 A-B), apreciándose como, a excepción de los poblados de Zarranzano y Suellacabras (Soria) donde las casas son menos largas (con superficies de $36 \mathrm{~m}^{2}$ y 36-40 $\mathrm{m}^{2}$ ), en los otros ocho las plantas son rectangulares, entre 12 y $15 \mathrm{~m}$ de largo por 3 a $5 \mathrm{~m}$ de ancho, lo que representa una superficie de unos 40 a $75 \mathrm{~m}^{2}$. En cinco de ellos la superficie oscila entre 40 y $50 \mathrm{~m}^{2}$ y en tres se enmarca entre 50 y $75 \mathrm{~m}^{2}$, estableciendo con claridad cómo la casa rectangular tripartita marca la pauta: hogar en el centro de la casa, el vestíbulo como espacio más público, la despensa en la parte trasera, como espacio más privado, junto la estancia subterránea, destinada a almacenamiento (Jimeno 2009).

Las dimensiones de estas casas suelen oscilar entre 12 y $15 \mathrm{~m}$ de largo, por unos 3 a $5 \mathrm{~m}$ de ancho, configurando superficies de entre 48 $\mathrm{m}^{2}$ y $75 \mathrm{~m}^{2}$, como se aprecia en los Castellares de Herrera de los Navarros (Zaragoza) donde se excavaron dos casas con plantas de 48 a 52 $\mathrm{m}$., que conservan los encalados en su interior y suelos de tierra apisonada; en El Castellar de Taniñe, Tiermes (habría que añadir la zona de silos) y Numancia (habría que añadir el corral anejo unos $24 \mathrm{~m}^{2}$ ); unos $60 \mathrm{~m}^{2}$ el Castillejo de 
Aldealcardo. Las dos casas de Suellacabras miden unos 22 y $38 \mathrm{~m}^{2}$, lo que hace sospechar, que no se tratan de casas completas. Las casas se estructuran en tres espacios sucesivos, accediendo de uno a otro por puertas laterales estrechas, dispuestas a veces alineadas (casa de Numancia) y otras alternando a uno y otro lado, como en el caso de Castilmontán (Somaén, Soria) y las tres estancias pueden estar utilizadas para los mismos fines, pero en orden diferente (Jimeno 2009).

Un ejemplo de estas casas es una de las reconstruidas en Numancia (Fig. 22), que mide $12 \mathrm{~m}$ de largo por $3 \mathrm{~m}$ de ancho, a los que hay que añadir el corral, unos $24 \mathrm{~m}$, dispuesto paralelo a la casa. A la primera habitación o vestíbulo se accede desde la calle y en ella se han dispuesto los molinos circulares de mano, para el procesado de bellotas y cereal, y el telar, para fabricar las prendas de vestir; a través de una trampilla abierta en el suelo se accede a la bodega o estancia subterránea $(2,5 \mathrm{~m}$ de ancho por $2 \mathrm{~m}$ de lado), donde se conservaban los alimentos; la habitación central con el hogar y bancos corridos era el centro de reunión familiar, donde se comía y dormía, reclinados en los bancos, construidos contra la pared, o sobre una estera en el suelo; la despensa, situada al fondo, servía para guardar alimentos y los útiles agrícolas (Jimeno et al. 2000; Jimeno et al. 2001).

El análisis de los accesos de la casa celtibérica muestra que los espacios son asimétricos entre sí, porque el paso de uno a otro está controlado por el anterior y no distribuidos, ya que únicamente disponen de un acceso. El recorrido es sencillo y de tipo lineal, ya que se inicia en la puerta de entrada y termina en la última estancia, que se convierte en espacio preeminente, por ser el lugar de destino, donde se guardan los recursos alimenticios de uso más diario, complementados por la zona, todavía más oculta, como es la estancia subterránea, que contendría el grueso de estos recursos (Fig. 23). El análisis de visibilidad, para conocer los espacios más públicos de los más privados, muestra como el vestíbulo o primera estancia es la más pública, resultando la tercera estancia o final la más privada, coincidiendo de esta manera con la estancia preeminente, donde se deposita lo más esencial de la vivienda, junto con la estancia subterránea, como es la base de la subsistencia. El índice de proporcionalidad de estas casas entre longitud y anchura, es aproximadamente de tres veces a favor de la longitud, lo que permite pensar en una modulación predeterminada para su construcción, indicándonos el grado de complejidad de la sociedad celtibérica. Se observa, como progresivamente las casas dejan de ser alargadas y de una sola crujía para adquirir una forma rectangular más proporcionada, lo que implica soluciones más complejas para su cubrimiento, $y$, aunque el espacio destinado a cada vivienda es similar, difieren las compartimentaciones internas que son más numerosas (Jimeno 2009).

Por el contrario, en el valle del Ebro se acusan fuertes influencias mediterráneas que se reflejan en la "Casa del Estrigilo" de Segeda (Mara, Zaragoza), una gran mansión de 283 $\mathrm{m}^{2}$, que se organizaba en torno a un gran patio central, al que confluían 11 habitaciones, cuyos suelos están acordes con los usos a los que se destinaron: de arcilla, para lugares de almacenaje, cocina o actividades de transformación; de mortero de yeso los relacionados con dormitorios y espacios anexos. Lo que demuestra que sus dueños conocían las costumbres griegas y se comportaban como ellos en diferentes aspectos, así como en el consumo de vino (Burillo 2005 y 2007).

\section{Consideraciones demográficas}

Schulten (1945) y Taracena (1954) realizaron cálculos sobre la densidad demográfica de la Celtiberia. Sus trabajos se centraron en la superficie ocupada por el caserío en los diferentes yacimientos, considerando que cada vivienda alojaría a una familia (Numancia tendría unos 8.000 habitantes, Termes 6.500 y para la Serranía Norte de Soria o zona pelendona, Taracena calculó 40.000 habitantes). También, se manejó el número de guerreros, considerando que estos representaban del $10 \%$ al 20 $\%$ de la población total; Schulten, de esta manera, calculó unos 340.000 habitantes para la Celtiberia de la zona del Duero y el Ebro. Estas aproximaciones plantean serias dudas, ya que las superficies calculadas para las ciudades celtibéricas no tienen en cuenta las ampliaciones 
de época romana, ni las diferencias de tamaño entre las casas y las calles de una y otra época.

Más recientemente Almagro-Gorbea (2001: 50-51), teniendo en cuenta la dificultad de fijar con exactitud los límites de la Celtiberia Histórica, pero utilizando como referencia las altas tierras del Sistema Ibérico y el Este de la Meseta, situadas por encima de los 1.000 m.s.n.m., con la excepción de la cuenca del Ebro, donde el límite puede considerarse este río y la depresión del Jiloca, calcula un área superficial para este territorio de unos 45.000 $\mathrm{km}^{2}$, teniendo en cuenta una densidad calculada en torno a unos $5 / 6 \mathrm{~h} / \mathrm{km}^{2}$, la población resultante oscilaría entre 225.000 y 270.000 habitantes, inclinándose más por unos 250.000 , entendiendo que tal cifra debe considerarse mínima, puesto que está calculada en las zonas más montañosas y despobladas de estos territorios, mientras que las principales ciudades de la Celtiberia tienden siempre a situarse en las zonas más abiertas y bajas, en relación con los principales valles fluviales y las vías de comunicación. Atendiendo a esto, parece lógico suponer que la densidad real de los territorios de estas ciudades debería de situarse en torno a los $8 / 10 \mathrm{~h} / \mathrm{km} 2$, lo que supondría una población teórica superior a 350.000 habitantes, pero que muy difícilmente superarían los 450.000 o 500.000 habitantes en total. También para el Valle Amblés se ha establecido una población total de unos 5.000 habitantes a fines de la Edad del Hierro, calculando $5 / 6 \mathrm{~h} / \mathrm{km}^{2}$ (Álvarez-Sanchís 1999: 306-308).

Un caso de contraste de datos lo proporciona Numancia, para la que existen referencias en los textos clásicos, como número de guerreros, y datos arqueológicos. Así, Apiano considera a Numancia "la ciudad más poderosa de los arévacos", calculando para el perímetro de la ciudad 24 estadios, que con la equivalencia de 185 metros por estadio, suponen un total de $4440 \mathrm{~m}$ de perímetro, lo que representa una superficie para la ciudad de unas 150 ha, lo que no responde a la realidad de la topografía y la documentación arqueológica. Schulten (1945), ajustándose al texto de Apiano, imaginaba a Numancia coronada por una acrópolis murada de 7,2 ha, dedicando el terreno de las vertientes hasta un total de 93 ha, sin defensa exterior, para acoger los pueblos refugiados. Taracena

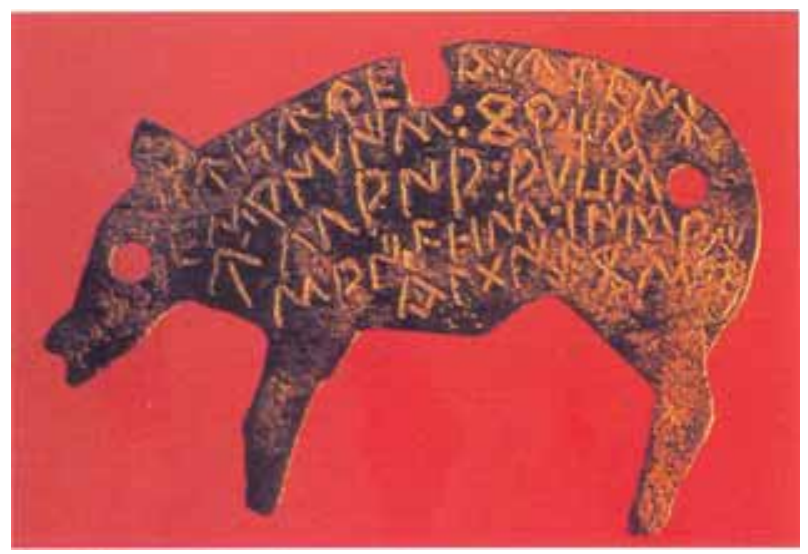

Figura 24.- Tésera de hospitalidad en forma de lechón, con inscripción celtibérica por uno de sus lados y perforación para ser colgada (García Merino 2005).

planteó objeciones a esta explicación por no encontrar referencia arqueológica, ya que las exploraciones demostraron la esterilidad de toda la gran llanura meridional, y consideró que la ciudad compacta y murada era mucho mayor de 7,2 ha, alcanzando una superficie intramuros de unas 22 hectáreas (Taracena 1954).

Otra vía de cálculo ha sido el número de guerreros citados en las fuentes clásicas. Así, Floro, Livio y Orosio, atribuyen a Numancia, para los años 143 y 133 a.C., 4.000 combatientes (o unos 16.000 habitantes); Apiano, 8.000 soldados antes de la guerra, y Veleyo indica que esta ciudad nunca armó más de 10.000 de sus propios hombres (Schulten 1945). En relación con la superficie de la ciudad y la producción del territorio, Schulten calcula que la población militar de Numancia en tiempo normal sería de unos 2000 guerreros (8.000 habitantes), y se refiere a guerreros de la comarca, no de la ciudad; cálculo que, según Taracena, resulta acertado desde el punto de vista económico y también referido a la superficie de 22 hectáreas calculada por este autor (unos 100 metros cuadrados por vivienda familiar, descontadas las calles).

Trabajos recientes en Numancia han permitido diferenciar el perímetro de tres ciudades superpuestas y precisar mejor sus diferentes extensiones. La ciudad celtibérica, más antigua, la destruida en el 133 a.C., ocuparía la extensión más pequeña de las tres, con una superficie construida de 4,35 hectáreas, de 


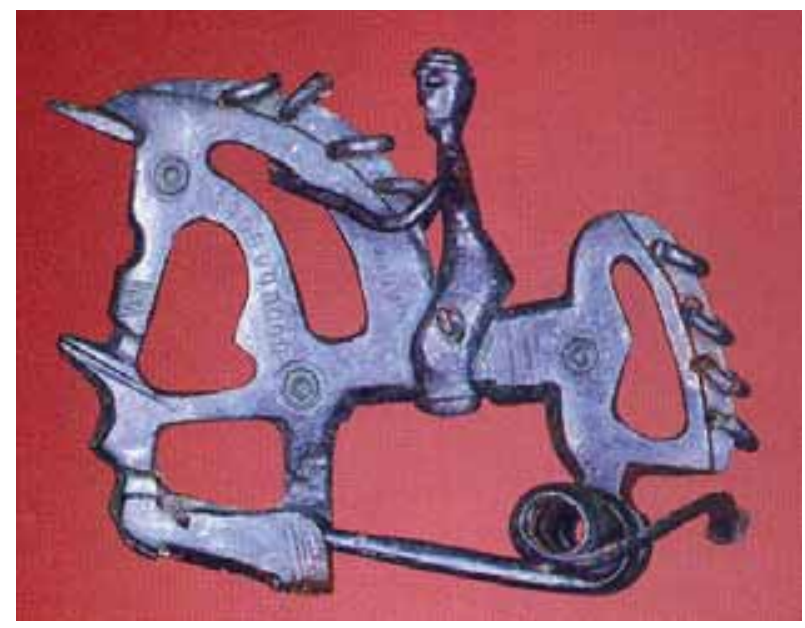

Figura 25.- Fíbula de caballito con jinete de la necrópolis de Numancia.

las 7,2 hectáreas totales, lo que permite calcular, asumiendo casas con patio o corral en torno a $80 \mathrm{~m}^{2}$, unos 1500 habitantes (Jimeno y Tabernero 1996; Jimeno et al. 2004). Para algunos poblados pequeños se han podido realizar cálculos sobre el número de casas que protegería su muralla, así, el caserío en Castilmontán estaría constituido por 33 casas (Arlegui 1992), que albergarían a poco más de 100 personas, $\mathrm{y}$ en Los Castellares de Herrera de los Navarros habría unas 22 casas, no superando el centenar de habitantes (Burillo y Sus 1988).

\section{Entidades políticas y formas de gobierno}

Será con la conquista romana cuando los textos clásicos aportan referencias e información para aproximarnos desde otra perspectiva a la organización social del mundo celtibérico, pero esta documentación, corresponde al momento de máximo desarrollo, cuando la Cultura Celtibérica ya se organizaba en ciudades, como unidad política fundamental. Las fuentes literarias hacen referencia, sobre todo, a dos clases de entidades como son las ciudades y los pueblos o etnias (arevacos, belos, titos y lusones), de carácter supracívico. Los lazos, mantenidos entre estos, serían de tipo genérico, mostrando afinidades étnicas, religiosas o culturales, aunque en ocasiones pudieran agruparse para la defensa común (Beltrán 1989). Estas referencias étnicas se vislumbran en el análisis global de los tipos e iconografía de las cecas celtibéri- cas (Burillo 1995), que marcan una verdadera frontera con el territorio vacceo del Duero medio, donde no se conocen ciudades que acuñen moneda y muestran otras características distintas de poblamiento, concentrado en grandes ciudades en las vegas de los ríos, idóneas para la agricultura, alternando con amplias extensiones de páramo prácticamente desocupadas.

Ahora, aunque no desaparece la organización gentilicia, ya que seguirá apareciendo como referencia de identidad en los textos y la epigrafía, sí tendrá que ajustarse a la nueva realidad, ya que la referencia política y jurídica primera para un celtíbero será ahora su marco urbano de procedencia, entendido con el territorio que controla y le da sentido, donde se distribuye la población rural, diseminada en entidades menores y dependientes, cabe la posibilidad que bajo este concepto de ciudad se cobije un grupo étnico y su territorio (ver cap. 8 de este número). A esta realidad se refiere Apiano (Iber., 98), cuando dice que "Escipión dio Numancia y su territorio a aquellos indígenas que le habían ayudado a conquistar la ciudad". Se trata de una organización de ciudades-estado, entidades autónomas que deciden sus alianzas y participación en la guerra, teniendo autoridad para acuñar moneda, emitir documentos públicos y dictar sus propias leyes que se exponían públicamente, como se demuestra en el caso de la Tabula Contrebiensis, escrita en latín, y otros tres bronces escritos en celtíbero (Contrebia Belaisca, Botorrita); así como epígrafes que hacen constar la comunidad

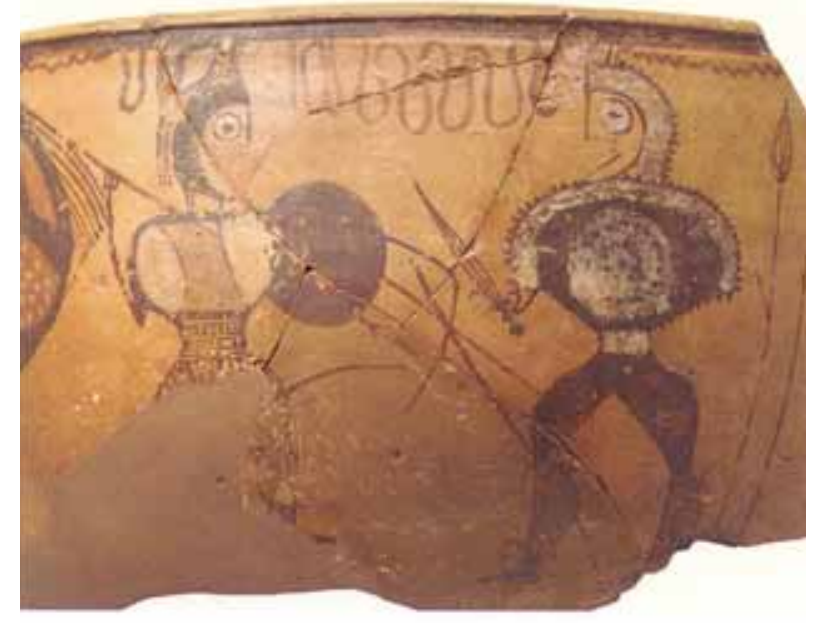

Figura 26.- Detalle del Vaso de los Guerreros de $\mathrm{Nu}$ mancia (A. Plaza, Museo Numantino). 


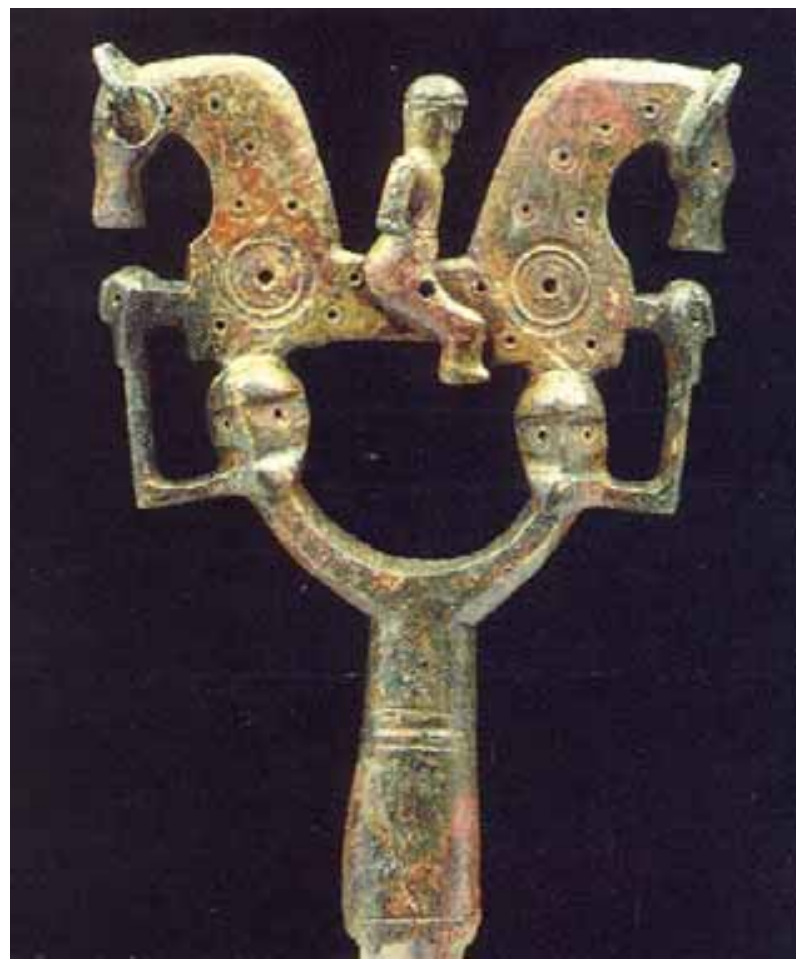

Figura 27.- Báculo de distinción con dos prótomos de caballo con jinete, con dos cabezas humanas que sustituyen las patas y otras cuelgan de los cuellos de los caballos, hallado en una de las tumbas de la necrópolis de Numancia.

del individuo y utilizan como referencia la ciudad (Beltrán 1989) (Fig. 24).

Estas relaciones y diferencias étnicas entre las ciudades celtibéricas quedan reflejadas en algunos episodios transmitidos por los textos romanos, así en el año 152 a. C., después de pactar las ciudades celtibéricas una tregua con Marco Claudio, general romano, cada una de ellas envían legados o embajadores a la propia Roma, donde el Senado les dispensa distinto tratamiento: "llegados los legados a Roma, los de los belos y titos, como amigos de los romanos, fueron recibidos en la ciudad; a los de los arévacos, se les mandó acampar allende el Tiber, como enemigos, hasta que se hubiese deliberado sobre toda la cuestión. Cuando pareció oportuno darles audiencia, el pretor introdujo primeramente a los aliados, separadamente por ciudades" (Polibio, 35,2).

Existen referencias a la forma de gobierno de estas ciudades, aludiendo a jefes, magistraturas, consejos y asambleas, lo que muestra una organización compleja. Inicialmente, se citan jefes y dos tipos de asambleas, una de ancianos (seniores), poniendo de manifiesto la existencia de un "grupo", que poseía mayor capacidad de decisión y otra de tipo popular en la que participaba el pueblo en armas (iuniores), que decidían sobre aquellos asuntos que afectaban a la colectividad. La diferencia sobre la composición de estas dos asambleas alude también a la existencia de grupos de edad, entre seniores y la iuniores; es decir, está reflejando una organización no parental de contenido social, con enfrentamientos frecuentes entre ambas, al entender, de manera diferente, lo que era mejor para la ciudad, como ocurre en el caso de Lutia, cuando el jefe numantino Retogenes se dirige a esta ciudad pidiendo ayuda para Numancia, ante su inminente caída. Los jóvenes de este enclave, según Apiano, "se declararon por los numantinos y empujaban a la ciudad a que les socorriese; pero los ancianos avisaron a Escipión", por temor a las represalias. También otro episodio indica que los arévacos despreciaron a sus enemigos, y por ello "la multitud reunida en pública asamblea decidió la guerra contra los romanos" (Iber., 94). Las asambleas nombraban jefes, legados y comisiones, como la referida antes de la caída de Numancia, compuesta por cinco miembros y presidida por el jefe Avaros, para gestionar la rendición con Escipión, que fueron asesinados a su vuelta por el pueblo ante las condiciones pactadas y bajo la sospecha de que hubieran tratado con Escipión la defensa de sus propios intereses (Apiano, Iber., 96).

Destacan las citas de líderes o jefes militares, elegidos por la Asamblea, para hacer frente a determinadas situaciones o necesidades bélicas, en reconocimiento de su valor, capacidad militar e, incluso, cierta aureola religiosa, lo que muestra la importancia de la guerra como forma de adquirir prestigio y riqueza, que tiene la máxima exaltación en el combate singular, reflejo de la ética agonística celtibérica, plasmada en la iconografía, especialmente destacada en las representaciones de bronce y cerámica, como se ha interpretado el "vaso de los Guerreros" (Romero Carnicero 1999: 51) (Fig. 26). Es el caso del jefe Caro, "famoso por su valor", elegido conjuntamente por los numantinos y segedenses para hacer la guerra contra el ejército de Nobilior (153 a.C.). A la muerte de Caro los arévacos congregados en Numancia escogen a Ambon y Leucon. 
Después será el jefe Litennon quien pacte la paz con Marcelo, posteriormente se citará a Megara y ya, en época del cerco de Escipión, a Retogenes, de sobrenombre Caraunios "el más esforzado de los numantinos" (Iber, 93). En diferentes ocasiones se menciona la figura de legados o heraldos enviados para negociar, uno de ellos cubierto con piel de lobo es enviado por los nertobrigenses, en el año 152 a.C., para tratar de un acuerdo de paz con el cónsul Marcelo, quien puso como condición que el acuerdo fuera firmado por todos los celtíberos (Appiano Iber., 48). También se alude en Numancia a la existencia de magistrados, ya que, el año 137 a.C., tras el desastre sufrido por el ejercito romano de Mancino e iniciadas negociaciones de paz, el cuestor Tiberio Graco trata con los magistrados de la ciudad para que le fueran devueltas las tablillas de cálculos y cuentas de su gestión, que formaban parte del botín tomado por los numantinos (Plutarco, Tib. Grac., 5,5).

Algunas veces se mencionan sirvientes o "esclavos"; así conocemos la existencia de población al servicio de estas élites, como se observa en el episodio que describe Apiano (Iber. 93) sobre la audacia de Retógenes, que consigue cruzar el cerco de Escipión, acompañado por cinco clientes y cinco "criados", para ir a pedir ayuda a las ciudades arévacas. Este tipo de relación clientelar asimétrica, entre individuos de mayor prestigio o valía y grupos de menor nivel social, está bien documentada en las referencias escritas sobre los celtíberos. La existencia de jerarquización en la organización de Numancia y las ciudades celtibéricas se puede deducir sobre otro pasaje referido también a Retógenes que sobresalía "entre todos los ciudadanos por su nobleza, riqueza y honores". (Valerio Máximo, III, 2, ext. 7).

Ante este conjunto de referencias que nos transmiten las fuentes escritas algunos estudiosos consideran que la sociedad celtibérica, hacia el siglo II a.C., ya habría evolucionado de una sociedad igualitaria a una de jefatura, aún muy primaria; es decir, no sería la sociedad celtibérica una sociedad de jefatura constituida formalmente, como la que se reconoce entre los pueblos iberos, ya que no se constata una autoridad individual consolidada, un jefe de tribu, un jefe de ciudad, que dirigiera los asuntos en tiempos de paz y que en la guerra comanda el ejército (García Gelabert 1990-91: 105), Estas diferencias interpretativas son consecuencia de la dificultad que plantea no sólo el registro arqueológico, sino también el etnográfico, utilizado frecuentemente como referencia, para determinar con claridad los distintos grados de complejidad social (Renfrew 1982: 14), a través del acceso desigual a los recursos, aparición de bienes escasos (objetos de importación o artefactos muy elaborados), que indicarían la existencia de sociedades no igualitarias (Salinas 2008: 89; Arenas 2005: 400). A estos datos de jerarquización social, se unen otros, como la posesión de caballo, como referente de riqueza (Fig. 25). La proporción calculada entre jinetes e infantes en los conflictos bélicos sería de $20 \%$, es decir de cada cinco guerreros uno era jinete. Según las fuentes, desde mediados del siglo III a. C.- y aún desde antes en la Celtiberia- existía una verdadera caballería de jinetes no aristócratas, liderada por aristócratas caballeros (Quesada 2006: 156158).

Pero los datos de las fuentes permiten también entrever la convivencia de un poder urbano de tipo jerárquico, reflejado en las asambleas, con el peso que siguen jugando los grupos parentales en el reparto de recursos, lo que estaría mostrando la compatibilidad de un poder urbano con capacidades últimas de decisión, con el de los grupos de parentesco, como intermediarios en el acceso a la tierra a cultivar. Por lo tanto, el peso de la gens, incorporada a lo urbano seguiría jugando su papel en todo el entramado de las relaciones políticas que sustentaban la ciudadestado. Aunque el panorama es complejo y de difícil concreción, hay bases para sostener que en el contexto del marco urbano celtibérico se mantendría el antiguo modelo social campesino de familias nucleares, con tendencia igualitaria en cuanto a sus posesiones y cuya relación seguiría regulada por los grupos familiares extensos, que aparecen recogidos en las inscripciones celtibéricas, a partir del siglo II a. C. (Ortega 2006: 172; ver cap. 8, de este volumen) Este planteamiento se vería apoyado por las características rurales de estas ciudades, ya que la mayoría de la población vive en el campo, manteniendo el esquema doméstico de sus viviendas, por lo tanto los que llevan las armas y cultivan los campos serían los mismos, a lo que se añade la ausencia en el registro arqueológico de espacios públicos 
civiles o religiosos y de arquitectura monumental. No obstante, este último aspecto, quizás por falta de documentación arqueológica, no encaja bien con algunos datos que nos transmiten los textos romanos, cuando aluden al sitio donde se reúne la asamblea de la ciudad de Lutia, aunque la referencia tiene poca precisión (Apiano, Iber., 93); como en el caso de Tiberio Graco, cuestor con el cónsul Mancino, cuando intentaba que los numantinos le devolvieran las tablillas de su gestión administrativa, para no dar lugar a sus enemigos de calumniarle, "llamó afuera a los magistrados", se entiende del edificio donde estaban reunidos (Apiano, Iber., 80); sin duda alguna, es más evidente, cuando Fulvio Flaco fue enviado para poner fin al levantamiento de los celtíberos en el año 93 a.C., y en la ciudad de Belgeda, el pueblo, ansioso de levantarse en armas, quemó al consejo, que vacilaba, junto con el edificio (Apiano, Iber., 100).

En apoyo de lo planteado anteriormente, estaría la interpretación que se ha hecho del documento sacro, conocido como Bronce 1 de Botorrita, hallado en la ciudad celtibérica de Contrebia Belaisca, relacionada con la diferente lectura del término bintis, que significa "magistrado", que aparece en el documento asociado a los catorce individuos mencionados en él, por el de kentis, "hijo". Este termino iría situado delante del patronímico de la totalidad de los catorce individuos mencionados en el documento, relacionados todos con cuatro lugares de procedencia, lo que estaría transmitiendo un origen, para la formación de la ciudad de Contrebia Belaiska, por sinecismo de cuatro grupos de diferente procedencia. A este referente aludiría también el propio nombre de la ciudad, que significa conjunto de casas o reunión de viviendas, lo que refleja su conciencia de pertenencia a la ciudad, pero al

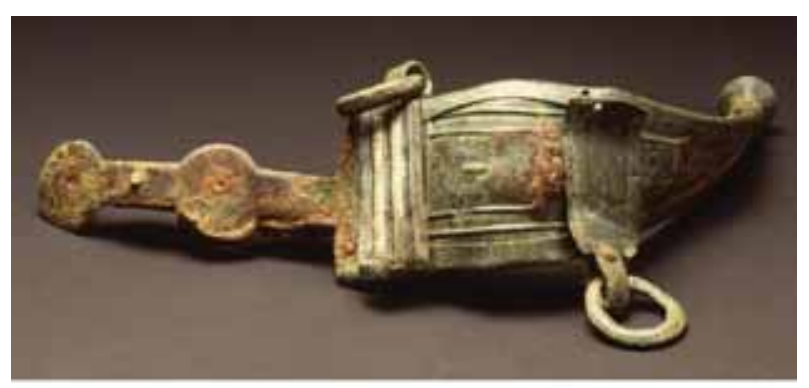

Figura 28.- Puñal biglobular con vaina enteriza de bronce, hallado en la necrópolis de Numancia. mismo tiempo también a su grupo de parentesco (Marco 1999; García Quintela 2002: 67).

No obstante, paralelamente a lo planteado anteriormente hay que tener en cuenta también la fuerte incidencia de los resultados de la guerra contra Roma, que conllevaron múltiples destrucciones, arrasamiento de campos y reparto de tierras, imposición de productos y tasas para el control de la producción, con la eliminación de excedentes, y alteración de formas de vida tradicionales; todo ello unido o la dedicación continuada a la guerra de parte de la población, como mercenarios, por lo que la fundación de ciudades será ahora impulsada o controlada por Roma diferenciandose de lo que pudiera ser un proceso endógeno, ya que se basa siempre en una derrota, destrucción o sometimiento previo de los presuntos beneficiados por la medida romana (García Quintela 2002: 67).

\section{Reflejo de la organización urbana en el ritual funerario}

En esta época, los ajuares de las necrópolis del Alto Duero, como las de Ucero, Osma y sobre todo la de Numancia, excavada recientemente, a las que se une la recientemente publicada de Arcobriga, en el Alto Jalón (Lorrio y Sánchez 2009), acusan cambios sustanciales en relación con la organización urbana, ya que se observa un aumento significativo de los elementos de adorno y un menor peso de las armas. La necrópolis celtibérica de Numancia permite conocer su uso a lo largo de unos 75 años, unas tres generaciones, y en ella se puede apreciar, cómo desde una base tradicional, vinculada a las armas y panoplias de guerrero, y donde el componente simbólico de los adornos, menos frecuentes, está relacionado con lo funcional o uso efectivo de los objetos (broches de cinturón de tipo Bureba más pequeños y funcionales e, incluso, aparecen reparados y reaprovechados), se va dibujando un cierto cambio, manifestado en un menor peso real y simbólico de las armas a favor de los elementos de adorno y de distinción personal, que hay que relacionar con la incidencia progresiva de la organización urbana, que conlleva cambios ideológicos que marcan las 
relaciones sociales, manifestándose en nuevos referentes de identidad y consideración de riqueza e, incluso, en cambios en la dieta alimenticia (Jimeno et al. 2004).

En este sentido, se ha sugerido una relación entre el empobrecimiento, simplificación de los ajuares y rarificación de las armas, que se observa en algunas necrópolis del Alto Tajo, y el desarrollo de la ciudad. Esto habría provocado una evolución de las poblaciones celtibéricas hacia una organización social de tipo urbano, con la consiguiente disolución de los vínculos sociales, basados en el parentesco, y el paso desde un sistema de propiedad, reclamada colectivamente, a otro de modo individual (Ruiz-Gálvez 1992: 345). El estatus parental, manifestado a través de los ajuares guerreros, habría perdido su valor simbólico. Pero lo que se observa en Numancia y otras necrópolis del Alto Duero-Jalón, relacionadas con ciudades, como Termes, Uxama o Arcobriga es el mantenimiento de las armas, e, incluso, la incorporación de nuevos tipos de espadas y puñales (Lorrio 1997: 316) (Fig. 28), pero acompañadas de cambios en la composición de los ajuares, que tienden a una mayor riqueza, aunque ésta ya no se manifiesta sólo en el armamento sino, sobre todo, en el adorno. Estaríamos asistiendo a un desarrollo de lo simbólico, cada vez más despegado de lo funcional, que se plasma en la aparición de piezas generadas no tanto para ser usadas como para ser mostradas (Jimeno et al. 2004).

Se asume que estos cambios en el ajuar funerario estarían relacionados con los nuevos planteamientos ideológicos que conllevaron el desarrollo de la ciudad y el afianzamiento del sistema de propiedad individual, desde fines del siglo III a.C., regidos por élites ecuestres de tipo urbano. Los gustos y exigencias de esta nueva clase social conllevarían un desarrollo del artesanado a su servicio que, en el caso de Numancia, se plasma en los trabajos de broncistas y orfebres: grandes broches de cinturón con escotaduras, placas articuladas de gran contenido iconográfico, báculos de caballito y de cabezas humanas (Fig. 27) (Jimeno et al. 2004) y la rica iconografía céltica de la cerámica numantina (Wattenberg 1963; Romero 1976, Olmo 1986). Estas ricas artesanías, que incorporan en su creación formas mediterráneas y de La Tène, representan la nueva expresión del estatus social basado en la riqueza, como alternativa al sistema anterior que ponía su referencia en las armas (Almagro-Gorbea 1996: 123; Almagro-Gorbea y Torres 1999: 104). En este sentido, el texto de Valerio Máximo (3, 2, ext.7), que indica como el numantino Retogenes "hizo un montón de materiales inflamables en su barrio, el más hermoso de la ciudad, y le prendió fuego", sería muestra de esta realidad urbana.

\section{Transformación del territorio conquista- do}

La información de la conquista de la Celtiberia muestra dos actuaciones de la administración romana bien distintas, ya que en un primer momento, tras la primera guerra contra Roma, los tratados firmados por las ciudades celtibéricas (probablemente sólo las del valle del Ebro), tras la batalla de Mons Caunus, con T. Sempronio Graco, representó un largo periodo de paz (desde el 179 a 153 a. C.) y se observa una voluntad por parte de Roma de mantener la estructura territorial celtibérica. No obstante, podemos apreciar cómo en el Senado Romano hay dos posturas contrapuestas, que se vuelven a poner de manifiesto en la Segunda Guerra Celtibérica (153133 a.C.), ya que frente a la postura de Marcelo, que pacta con las ciudades celtibéricas acuerdos de paz, que duraron ocho años (152-144 a.C.), termina por imponerse la línea dura, representada por Escipión Emiliano, que concluye con el aniquilamiento de Numancia; es decir se impone la destrucción, como medio de conquista, como represalias contra las revueltas locales, llegando al arrasamiento total, para imponer sobre el sistema organizativo celtibérico formas de vida romanas (Sánchez Moreno 1993: 10; Caballero 2003: 83).

No obstante, la investigación sobre este aspecto se divide entre los autores que piensan que Roma no aportó cambios significativos a la planificación urbana celtibérica (Bendala et al. 1986) y los que se inclinan por considerar que no pondría en práctica una política urbana hasta el inicio del siglo I a. C. (Pérez Vilatela 1992). Lo que parece claro es que la presencia del dominio romano se hará más evidente a finales del siglo II e inicios del I a. C., que es cuando se observa una decidida actividad urbanística con la creación de ciudades (Caballero 2003: 72). 


\subsection{La ordenación del poblamiento}

Tras el final de las Guerras Celtibéricas, con la toma de Numancia en el 133 a.C., Roma envió a Hispania, según indica Apiano (Iber., 99), una comisión senatorial "como era costumbre", formada por diez senadores "a las zonas de Iberia recién adquiridas" que tenía como misión la recogida de información, para la elaboración de un plan de actuación sobre las zonas conquistadas para "organizarlas sobre una base de paz" (Pina 1997: 83).
A finales del siglo II a. C., Roma impulsará la creación de nuevas ciudades en llano, con una trama urbana reticular, de tipo itálico, y una superficie entre las 10 y 20 hectáreas. Se trata de núcleos que acuñan moneda con letreros indígenas, algunas de nueva fundación como Bilbilis (Valdeherrera), la nueva Segeda (Durón de Belmonte) y Orosis (¿La Caridad de Caminreal?); a otras se les aplica una gran reestructuración urbanística, como a Contrebia Belaiska (Botorrita, Zaragoza). Se sitúan en zonas de explotación de recursos agrícolas o

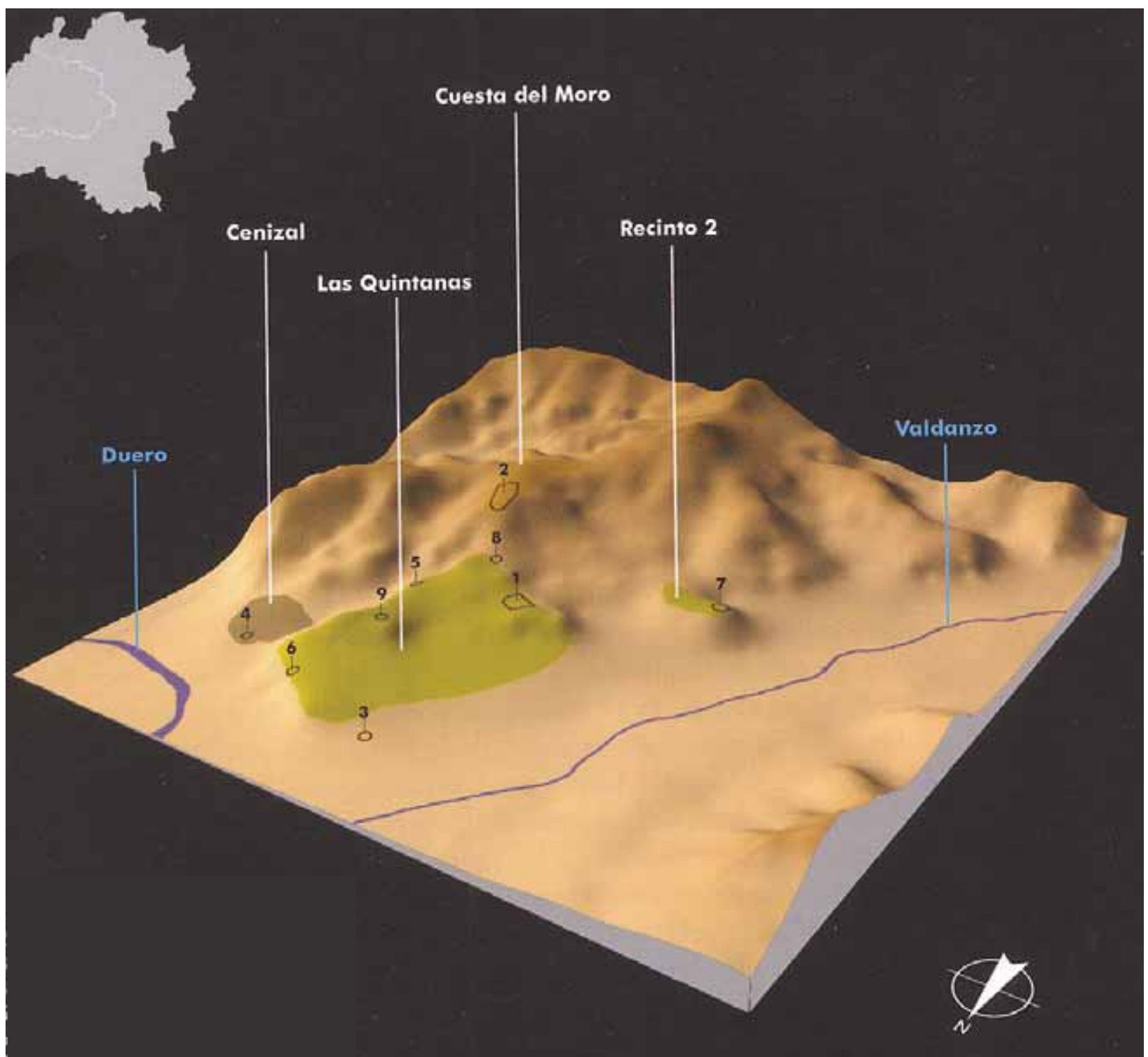

Figura 29.- Croquis del cerro donde se asentó Segontia Lanka (Langa de Duero, Soria) y los sondeos realizados, que han proporcionado restos de dos recintos murados (Tabernero et al. 2005, Empresa Areco 2005). 
ejercen el dominio sobre los asentamientos mineros, como La Caridad (Caminreal, Teruel), que pudo jugar un papel significativo en relación con las explotaciones de metal de hierro de Sierra Menera (Teruel), potenciando así el desarrollo de nuevas vías comerciales. Esta ciudad muestra una sociedad muy jerarquizada, con grandes cambios en relación con la estructura familiar nuclear celtibérica anterior, reflejados en las características de los espacios domésticos, ya que sólo la estancia principal de una de estas mansiones tiene más superficie que una casa celtibérica anterior (Vicente 1991; Burillo 1998: 276).

Paralelamente, a esta política de nuevas fundaciones se desarrollará otra de mantenimiento de los núcleos precedentes, sobre todo en el Alto Duero, introduciendo nuevas planificaciones y ampliando su superficie, como es el caso de Numancia, que aumenta ligeramente su recinto por la zona sur, ajustándose a la urbanística indígena anterior, pasando de 7,6 a unas 9 ha. También Uxama (Osma, Soria) se verá agrandada, aunque en este caso la ciudad imperial posterior ha barrido los límites de esta ampliación (García Merino 2001; Jimeno 2000). En este sentido hay que pensar que el flujo de emigrantes itálicos no se establecería sólo en núcleos urbanos de nueva fundación, sino que también se instalarían en los asentamientos indígenas, formando agrupaciones para defender sus intereses (Mangas 1983: 245).

Es posible que en estos casos Roma estuviera interesada en convertir una serie de poblados indígenas en centros comarcales, ampliando su caserío, conservando el nombre de la ciudad y propiciando la actuación de los líderes locales que buscarían su engrandecimiento y el de sus comunidades, favorecido por el flujo de itálicos. Para ello fomentará o retraerá conforme a sus intereses políticos esta tendencia urbana, impulsando el desarrollo de unas ciudades, favoreciendo el estatus y privilegios de determinadas jerarquías indígenas o redistribuyendo a la población en centros de nueva planta. Además de las ciudades localizadas, se conoce la existencia de un número mayor de cecas o ciudades que acuñan moneda, que no han podido ser localizadas todavía, pero que constatan el desarrollo urbano, que tuvo lugar tras la conquista romana y que no llegarían a época augustea por desapare- cer, probablemente, en los conflictos civiles que se desarrollaron durante el siglo I a.C. (Jimeno y Arlegui 1995; Burillo 1998).

Por otro lado, la fundación de algunas de estas ciudades aporta indicios de la puesta en marcha, por parte de Roma, de una política agraria que conllevaría el control y fijación de los excedentes de población dedicados a la guerra. Así, Apiano (Iber., 100) cita la fundación de una ciudad, por Marco Mario, cogiendo tierras de la ciudad de Colenda, hacia el 102 a.C., como concesión a los veteranos de guerra celtíberos, que habían participado en las contiendas contra los lusitanos, para evitar el bandidaje al que les obligaba su pobreza. Los asentamientos de nueva planta alcanzan, a lo largo de los siglos II-I a.C., un notable incremento (el 74,60 \%), en la zona del Alto Duero (Jimeno y Arlegui 1995), observándose una tendencia a ocupar zonas de aprovechamiento agrícola.

Este dominio romano continuará con fuerza en los inicios del siglo I a.C., como se observa en la aplicación de esta política de control y sometimiento sistemático sobre las ciudades de la zona del Duero, a través de las campañas de Tito Didio, del 98 al 94 a. C., que supuso la destrucción de Termes (Montejo de Tiermes, Soria), obligando a sus habitantes a bajar al llano (App. Iber., 99). También, en el 87 a.C., Valerio Flaco intervino en Belgeda, por la toma de decisión diferente entre el Consejo y el pueblo a favor de Roma, que terminó con la quema de los consejeros en el edificio del Consejo. Este panorama urbano refleja un aumento de la centralización política, que se traduce en un aumento de la jerarquización del territorio, concentrándose el control en un número menor de ciudades, que reforzarían su poder político y económico con la reanudación de las acuñaciones en plata (Burillo 1980 y 1998). No obstante, estas ciudades mantendrán un fuerte carácter indígena, entremezclándose en la cultura material las producciones locales con las aportaciones romanas, como sucede en La Caridad (Caminreal, Teruel), Salduie (Zaragoza) o Segeda (Belmonte de Gracián, Zaragoza). Este dato abona la idea de que los destinatarios de estas nuevas fundaciones eran los itálicos emigrados a Hispania o indígenas ya romanizados. Un ejemplo del cambio en la composición de ciudades en la zona del Duero 
lo tenemos en el yacimiento de Las QuintanasLa Cuesta del Moro, en Langa de Duero (Soria), cuyas ruinas se relacionan con Segontia Lanka, fundada en esta nueva etapa, como lo indican el estudio de los materiales arqueológicos, que aportan una cronología de finales del siglo II e inicios del siglo I a.C., fecha refrendada por los denarios republicanos (Tabernero et al. 2005) (Fig. 29).

Además de los numerosos materiales de hierro relacionados con la construcción, el trabajo de la madera y actividades agrícolas, así como el frecuente hallazgo de pesas de telar en las estancias, evidencias de forja y trabajos sobre asta, llama sobremanera la atención la constante presencia de armas en contextos domésticos, que hay que relacionar con la inseguridad continuada, a lo largo del tiempo de vigencia de la ciu- dad, sucediéndose numerosos conflictos bélicos, desde las campañas de Tito Didio en el 98 a.C. contra Termes, en el entorno próximo, y posteriormente las Guerras Sertorianas (80-72 a. C.), que conllevaron una serie de conflictos, desde el año 75 a. C., con campañas centradas en el valle del Duero y mundo vacceo, así como en entornos próximos del valle del Duero, como el de la ciudad de Clunia donde fue sitiado Sertorio o los ataques a las tierras de Termes, de Pallantia y Cauca, finalizando con el sometimiento de Termes, Clunia y Uxama, una vez asesinado Sertorio (72 a.C.).

Estos datos probarían la existencia de contingentes militares asentados en las ciudades, lo que explicaría también que Segontia tuviera dos potentes recintos amurallados y una amplia extensión. La presencia de numerosos pila y un lote

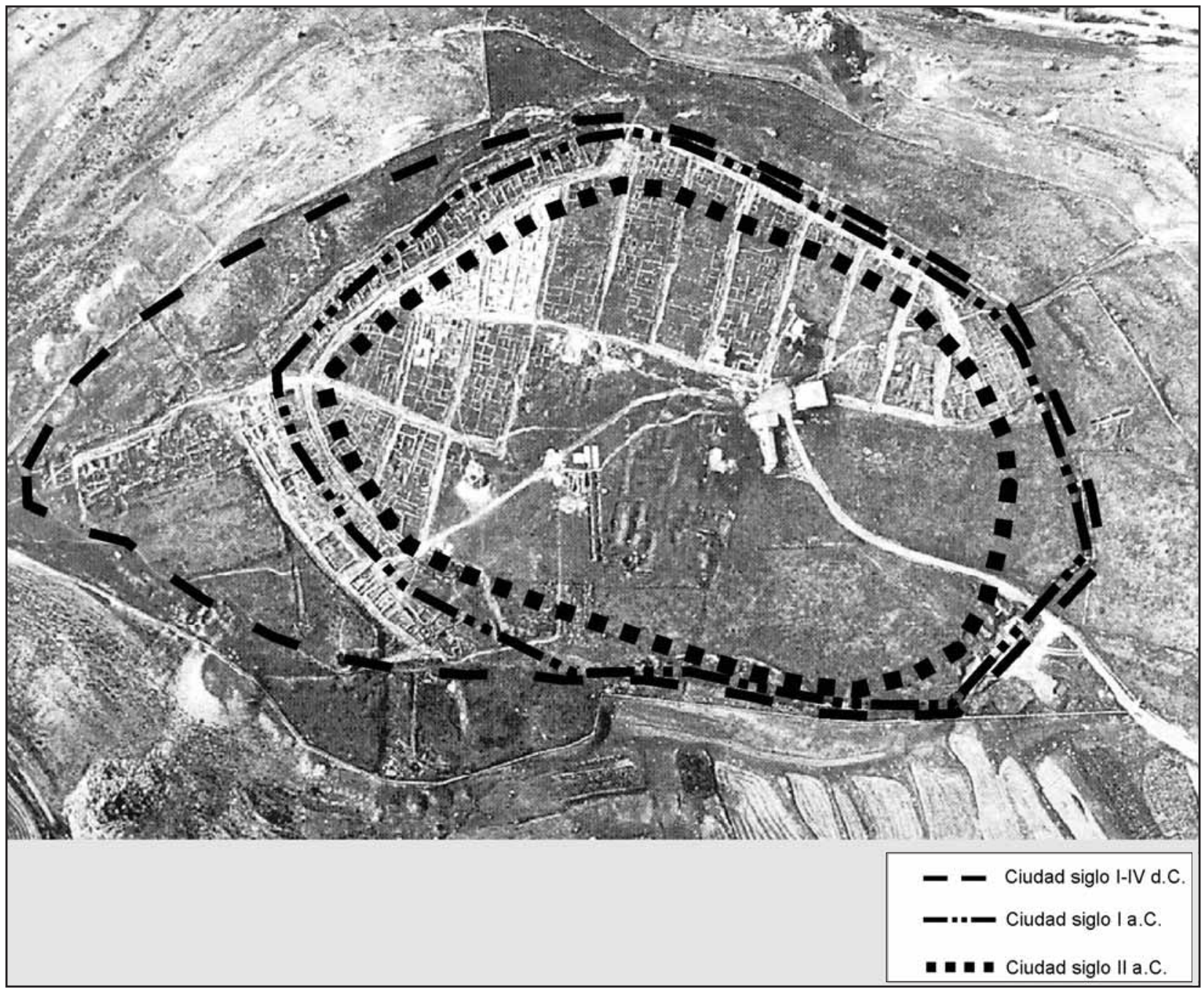

Figura 30.- El perímetro de la muralla de la ciudad celtibérica de Numancia (s. III-II a.C.) y sus diferentes ampliaciones, en el s. I a.C. y época imperial romana. 
de glandes de plomo en las casas; así como el hallazgo de espadas de La Tène sin rematar, a la espera de forjarles la punta y los filos, estarían mostrando el armamento característico de los legionarios romanos y cómo eran las ciudades las que se encargaban de la movilización y equipamiento de las tropas, como relata Plutarco (Sertorio, 6) en las narraciones que hace de las Guerras Sertorianas. Este contexto militar se reafirma con la emisión de monedas de plata y bronce, que se datan en el tránsito del siglo II y la primera mitad del siglo I a.C. (García Merino 1975), al igual que las de otras cecas de esta zona, que estarían destinadas al pago de los contingentes de las tropas combatientes en el bando sertoriano, Estaríamos ante un tipo de ciudad, fundada tras el final de las Guerras Celtibéricas (caída de Numancia en el 133 a. C.), probablemente con ejércitos mixtos, de celtíberos e itálicos, que muestran ya un proceso claro de romanización (Tabernero et al. 2005).

El control romano del territorio condicionó profundos cambios sociales y económicos, vinculados al desarrollo urbano. Se acusa, ahora, una clara diferenciación entre el valle del Ebro y el Alto Duero. La zona citerior mostrará un potente desarrollo con la aparición de nuevas ciudades y la ampliación de otras antiguas, adoptando modelos itálicos. También se amplió el número de las ciudades que acuñan moneda y se intensificó la producción con nuevos regadíos y explotaciones mineras. Estos cambios fueron proporcionando homogeneidad al territorio por encima de las diferencias lingüísticas y étnicas existentes. Por el contrario en el valle del Duero no se detecta una transformación socioeconómica similar, ya que el proceso de integración en la esfera romana será efectivo más tardíamente. Se acepta generalmente que las acuñaciones celtibéricas van a experimentar un notable aumento en relación con las guerras sertorianas (Domínguez 1988: 160); sin embargo también se ha visto en el florecimiento de estas acuñaciones, entre finales del siglo II y comienzos del I a.C. la plasmación de una condición de frontera, es decir de un territorio ya incorporado pero cuya organización u ocupación intensiva todavía no se ha efectuado (Knapp 1979: 471; Romero Carnicero 1992: 709).

\subsection{Urbanismo y arquitectura doméstica}

En esta fase se conocen ciudades que van a implantar la urbanística en retícula, de corte clásico, lo que será más frecuente en los esquemas urbanos de nueva planta, como las ciudades en llano, destacando el yacimiento de La Caridad de Caminreal (Teruel), que adapta modelos urbanísticos helenísticos, de estructura reticular, con calles perpendiculares, dotadas de aceras y alguna con canal para desagüe. Esta ciudad muestra una sociedad muy jerarquizada, con grandes cambios en relación con la estructura nuclear celtibérica anterior, reflejados en la diferenciación social de su urbanística totalmente romana, relacionada con el desarrollo de la producción y la creación de excedentes, vinculados con el control y la distribución de la riqueza minera del hierro, como se ha apuntado anteriormente. Entre las grandes casas excavadas, que alberga esta ciudad, destaca una de ellas, que ocupa $915 \mathrm{~m}^{2}$ de superficie, prácticamente cuadrada, con las habitaciones dispuestas en torno a un patio central de ocho columnas. Se han contabilizado en ella un total de 22 estancias con funciones diferenciadas: dormitorios, cocina, almacenes, habitaciones con fines artesanales e industriales. En el mosaico que preside el gran salón (oecus) figura la inscripción ibérica con el nombre de Likinete, probablemente su propietario. Esta gran casa representa la existencia de un dueño, que cuenta con el apoyo de la administración romana y que concentra en sus manos un importante poder económico y social (Vicente 1991; Burillo 1998: 276).

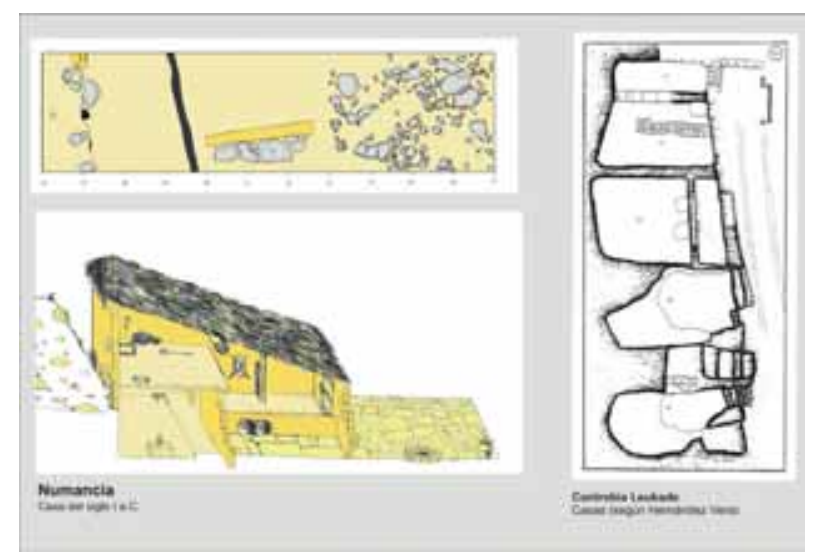

Figura 31.- Casas compartimentadas longitudinalmente de Numancia y Contrebia Leukade (probablemente del s. I a.C.). 
Por el contrario, en la zona del Alto Duero las ciudades mantienen la misma ubicación y, en gran medida, las características urbanísticas anteriores, acoplando las innovaciones y los cambios sobre esta base, como ocurre en Numancia, ya que aunque la Comisión de Excavaciones (1906-1923) mantuvo que se produjo una despoblación del cerro de La Muela, entre la ciudad tomada por Escipión en el 133 a.C. y la nueva ciudad, que se levantaría en época de Augusto, a partir del 29 a.C. Sin embargo, la documentación arqueológica conocida, la existencia de un significativo número de monedas autónomas y romanas fechadas entre el 133 y el 75 a.C. (cuya procedencia indica relaciones comerciales de Numancia con ciudades del valle del Ebro y del noreste peninsular), así como la información que alude a la participación de Numancia en las Guerras Sertorianas (GómezPantoja y Morales 2002: 303), hacen suponer que la ciudad no estuvo, o, al menos no por mucho tiempo, deshabitada, correspondiendo a este momento una ampliación de su perímetro urbano (Fig. 30), que mantiene la continuidad de su esquema indígena, ya que las nuevas manzanas de casas se organizan en calles concéntricas a las anteriores, así como la línea de muralla.

Es probable que correspondieran a esta ciudad los restos de casas que Schulten localizó en la Manzana IV, que denominó iberoromanas, situadas por encima de la urbanística de la ciudad celtibérica inicial y por debajo de la ocupación de época romana imperial, con una orientación ligeramente diferente a las anteriores, adosándose por su parte posterior a la muralla. Esta misma urbanística se ha podido documentar en los trabajos de limpieza realizados en la Manzana I, situada en el barrio sur, con casas de planta rectangular de mayores dimensiones (unos 12 metros de largo por unos 6 metros de ancho, con muros de unos $40 \mathrm{~cm}$ de grosor), orientadas norte-sur, acomodándose por su lado estrecho anterior al trazado semicircular de la calle, y por el lado opuesto o sur, a la línea de la muralla, de la que se conoce parte de su recorrido, ya que en gran medida quedó cubierta por la construcción de la ciudad romana posterior, de mayor amplitud. La superficie ocupada por esta ciudad sería algo mayor que la anterior, ya que se aproxima a las 9 ha, por lo que asumiendo una superficie total de 8,73 ha, con un espacio construido de 5,28 ha, podría calcularse la existencia de unas 628 casas, de $84 \mathrm{~m} 2$, o 528 , de $100 \mathrm{~m} 2$, lo que supondría un contingente poblacional de entre 2000 y 2500 habitantes, aunque probablemente con la valoración de espacios libres no alcanzaría los 2000 habitantes (Jimeno y Tabernero 1996).

Pero además, también en Numancia, en los inicios del s. I a. C., junto con las casas rectangulares de módulos tradicionales se observan ahora, en la zona norte, desbordando el límite de la muralla amortizada, casas compartimentadas no sólo transversalmente sino longitudinalmente (Fig. 31), lo que indica el aumento de necesidades y de los espacios de privacidad. En relación con los cambios de estas construcciones, cabe apuntar, que las posibles ampliaciones de las casas rectangulares anteriores, estarían condicionadas a hacerlo por los costados en detrimento de las casas contiguas, lo que conduciría a un módulo que ganaría en anchura, manteniendo la longitud para no romper la línea de fachada. Esta tendencia se acusa también en las estructuras semi-excavadas en la roca de las ciudades rupestres, como Tiermes (Argente 1990) y Contrebia Leukade, algunas con pavimentos de opus signinum (Hernández 2007: 75-91). En Contrebia Belaiska (Botorrita) los materiales constructivos muestran la fusión de tradiciones indígenas, conservadas en los suelos de tierra, paredes de adobe y tapial, sobre zócalos de piedra, y romanas, con el empleo de sillares, suelos de pavimento de "opus signinum" o el acabado interior de las paredes con estucos pintados y decorados con molduras y falsas pilastras (Beltrán 1988). No obstante, algunos yacimientos como Castilmontan (Somaén, Soria), en el valle del Jalón, continúan manteniendo las casas rectangulares tripartitas, con superficies de unos $75 \mathrm{~m}^{2}$, así como algunas construcciones del yacimiento de Castilterreño de Izana (Taracena 1941: 87).

\subsection{Incidencia romana en el gobierno de la ciudad}

A partir del final de las guerras celtibéricas y a lo largo del siglo I a.C. la relativa pacificación y la progresiva romanización proporcionaron una 
estabilidad creciente, conviviendo en los inicios aún las formas de vida tradicionales con las nuevas; así, en Contrebia Belaiska se construyeron edificios y casas de modelo itálico, pero se seguía escribiendo sólo en celtíbero. A través de los bronces de Contrebia (en lengua indígena y latina) conocemos aspectos de la estructura del gobierno de esta ciudad, con referencias al Senado y a los magistrados, mostrando la implicación de la influencia romana (Beltrán y Tovar 1982; Fatás 1980; Beltrán et al. 1996). La existencia de órganos de gobierno y legislativos de esta entidad, conlleva la construcción de edificios públicos, destinados a sede del gobierno municipal, donde se guardarían y archivarían los documentos públicos, como los aparecidos en esta ciudad. A este tipo de edificios hace referencia Apiano, cuando comenta cómo en la ciudad de Belgeda, en año 93 a.C., el pueblo quemó a su Consejo con el edificio que lo albergaba.

Este importante yacimiento está presidido en su acrópolis por una gran edificio monumental, de finales del siglo II a.C., que ocupa una superficie de unos $225 \mathrm{~m}^{2}$ (15 por $15 \mathrm{~m}$ ), realizado con paredes de adobe de gran tamaño, asentados sobre bloques de piedra caliza. El edificio está compartimentado en cinco estancias estrechas y rectangulares o trapezoidales, que se abrían al exterior por sendas puertas, a una galería porticada con tres columnas, Se creyó inicialmente que este edificio tendría una función político-religiosa, que fuera la Curia o Consejo (Beltrán Martínez 1988, pero posteriormente, se ha planteado, que pudiera tratarse de un horreum publicum (alma-

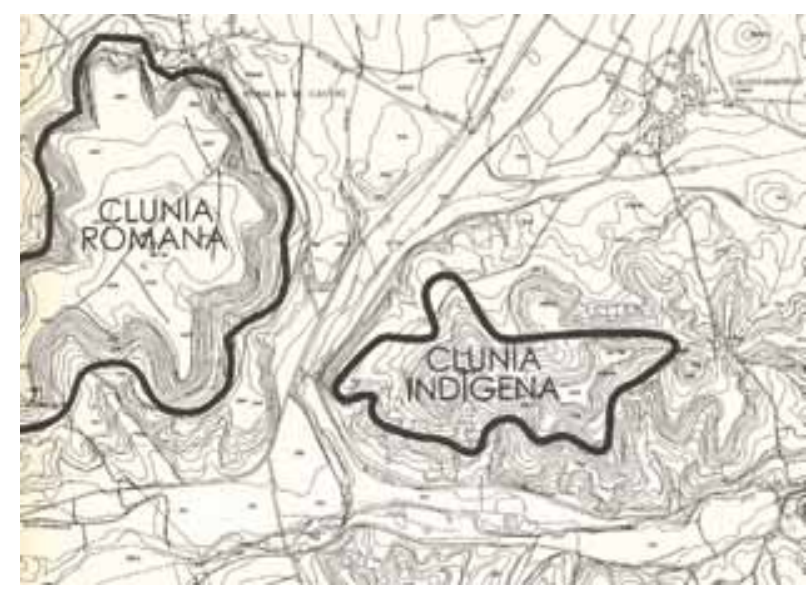

Figura 32.- Situación de la Clunia celtibérica y de la Clunia romana (Sacristán 2005).

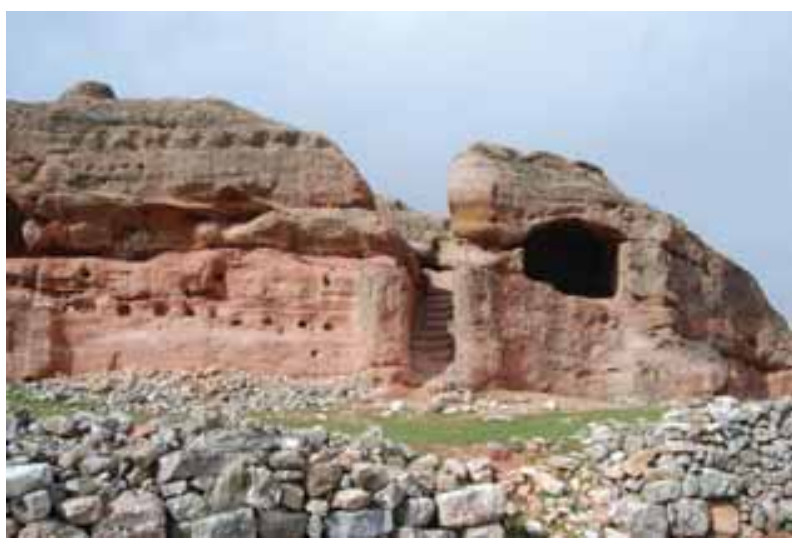

Figura 33.- Casas romanas en el barrio sur de Tiermes, con varios pisos excavados en parte en la roca y escalera de distribución para acceder a las distintas plantas o casas.

cén de grano), por los paralelos claros que guarda con otros referentes hallados en algunos yacimientos helenísticos de Asia Menor (Beltrán Lloris 2005).

\section{El nuevo orden romano tras las guerras sertorianas}

Las guerras sertorianas (83-72 a.C.) implicaron un amplio proceso de destrucción de las ciudades celtibéricas, que apoyaron la causa de Sertorio, Propretor de la Hispania Citerior, y defensor del partido popular frente a la dictadura de Sila. Las destrucciones se centraron sobre todo en las ciudades asentadas en llano, entre otras las de La Caridad de Caminreal (¿Orosis?), Belikion (¿Azuara?), Contrebia Belaiska (en el cerro de Las Minas de Botorrita), aunque continuará sin la categoría de ciudad, y muy probablemente de Sekaisa (Belmonte) y de Bilbilis (Valdeherrera) (Beltrán Lloris 1986: 485; Burillo et al. 1995: 258); es decir en aquellas fundaciones de nueva planta, acometidas por el estado romano para asentar aliados, lo que conllevaría un enfrentamiento entre romanos o entre indígenas romanizados. Serán tomadas por los pompeyanos, en el Alto Duero, las ciudades de Termes y Uxama, con la destrucción de esta última, que habían mantenido su ubicación inicial y probablemente Segontia Lanca, fundada a finales del siglo II a.C., tras la segunda guerra celtibérica, y quizás también, en la zona de Tierras Altas, el Castillejo de La Laguna. El levantamiento de estos núcleos ur- 


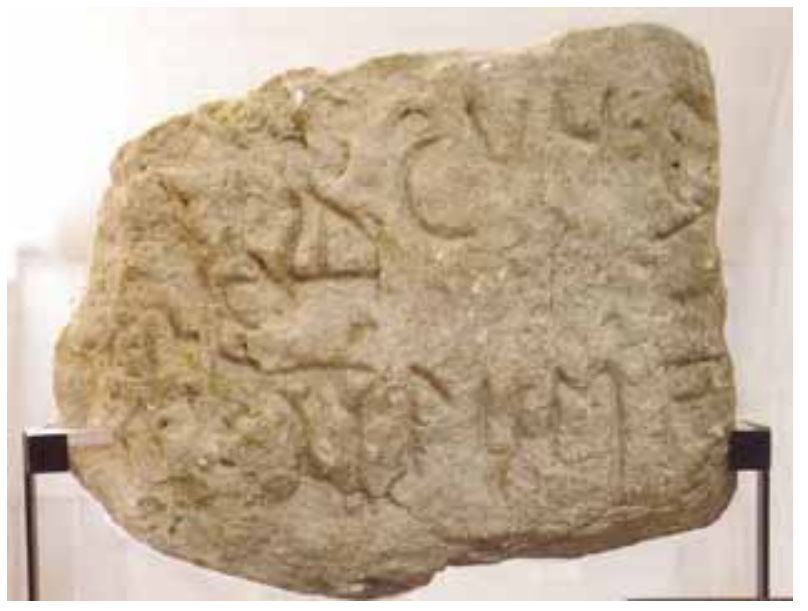

Figura 34.- Inscripción sepulcral de RECTUGENUS, en escritura celtibérica, de Segotias Lakas (Langa de Duero, Soria) (A. Plaza, Museo Numantino).

banos a favor de Sertorio, tienen unas connotaciones diferentes al de la etapa anterior, ya que su actitud suponía tomar partido en los problemas internos de la política romana.

De los 32 poblados conocidos, en la zona de Tierras Altas sorianas, en el periodo anterior, sólo ocho alcanzarán la etapa altoimperial. Cuatro de ellos son de fundación tardía y sin defensas, los cuatro restantes son lugares destacados que continúan desde la etapa anterior (Alfaro 2005: 303-305). De los poblados que sobreviven va a haber uno, de los dos grandes, que desaparece violentamente: El Castillejo de La Laguna, cuya destrucción hay que relacionar probablemente con este periodo de gran inestabilidad que para esta zona, bisagra entre el valle del Duero y el Ebro, debieron suponer las Guerras Sertorianas (83-72 a.C.), en las que se vio implicada Calagurris (Calahorra, en el Ebro), además de la proximidad de Contrebia Leukade (Inestrillas, La Rioja), ciudad entre otras, envuelta en los conflictos citados. Para compensar esta pérdida surge, desde un momento temprano del siglo I a.C., en el lugar de Las Gimenas de Villar del Río, el núcleo de población más importante en el alto Cidacos, en época altoimperial (Jimeno y Arlegui 1995; Alfaro 2005: 311-312). La desaparición de estas ciudades conllevó la creación por Roma, en algunos casos, de otras nuevas, a pocos kilómetros de las anteriores, que ocuparán lugares estratégicos en altura, acordes con su política de control y administración del territorio. Es decir, se trata de un cambio de ubicación física del asentamiento, pero para ejercer todavía mejor el control sobre su territorio, los recursos existentes y las vías de comunicación. Se produce este traslado en los casos de la Bilbilis Itálica, en el cerro de Bámbola, a 12 $\mathrm{km}$ de Valdeherrera, donde se sitúa la indígena (Burillo y Sus 1988) y algo similar sucede con la Clunia celtibérica (Los Castrillos) y la Clunia Sulpicia, en el Alto de Castro (Sacristán 1994 y 2005: 184) (Fig. 32) o la Segobriga indígena y romana (Burillo 1998 y 2007; Almagro-Gorbea 2005: 191). En época sertoriana, como apunta Romero Carnicero (1992: 710 y 2005: 435), se atisba para la zona del Alto Duero, como un referente generador de ulteriores cambios, una política romana enfocada a la organización del territorio que puede intuirse en ciertos cambios en el poblamiento $y$, en particular, en la aparición de formas innovadoras en el hábitat rural, fruto de una nueva concepción de explotación y distribución del suelo. En este contexto tendría sentido, para esta autora, la situación de frontera, apuntada más arriba y defendida por Knapp (1979: 471), en relación a las acuñaciones monetales, que desaparecerán a mediados del siglo I a. C., sirviendo de indicador probablemente de que el territorio ya había sido organizado.

Los emplazamientos de las principales ciudades celtibéricas del Alto Duero, Uxama, Termes o Numancia, así como otras próximas en el Jalón, como Arcobriga, o Contrebia Leukade, en valle del Alhama, se mantienen en el mismo sitio, volviendo a renacer con fuerza en época de Augusto, acusando ampliaciones y planificaciones de acuerdo con la urbanística romana

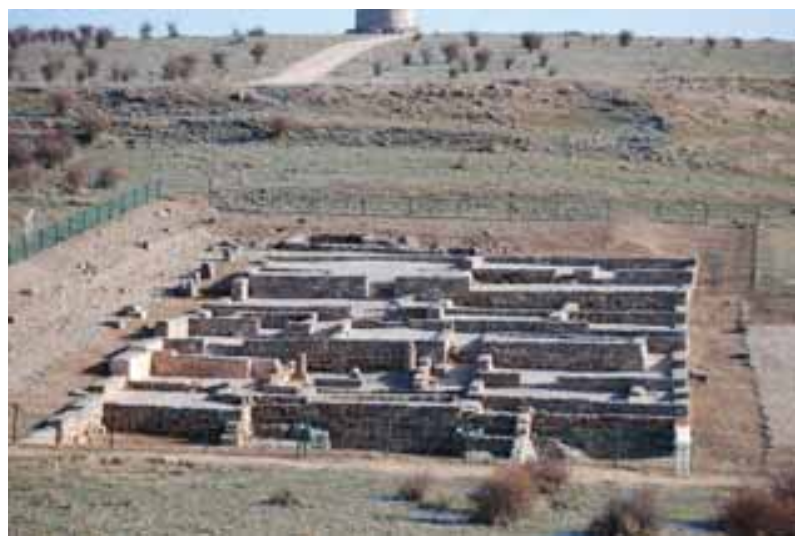

Figura 35.- Casa de los plintos de la ciudad romana de Uxama Argaela. 


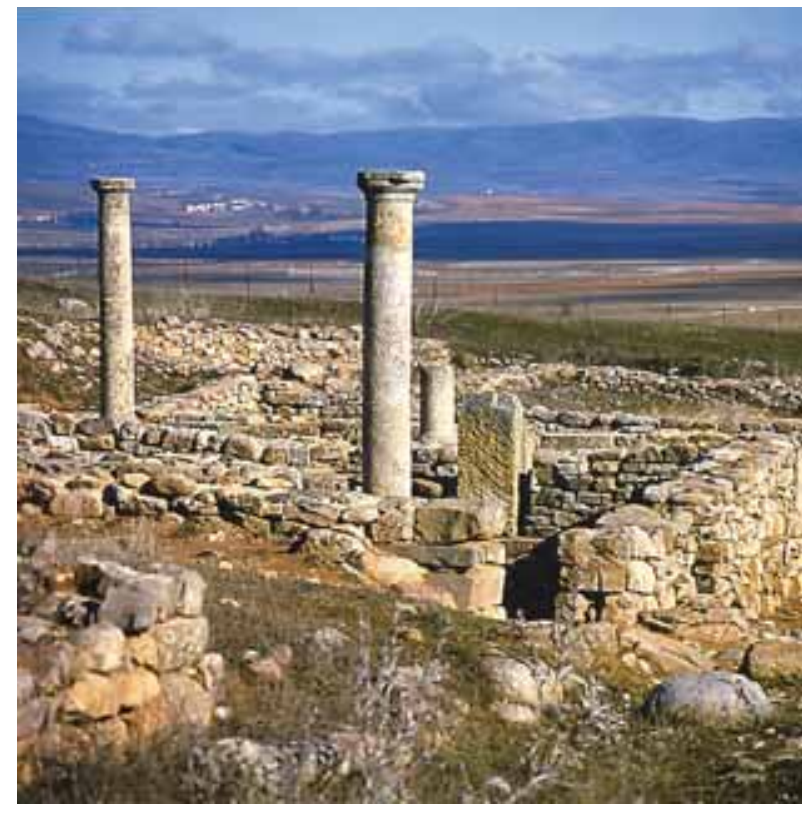

Figura 36.- Casas romanas con patios porticados del barrio sur de Numancia.

(Fig. 33). Así Termes verá desplazado su caserío hacia la zona baja y una ordenación en torno al foro que se dispone en una zona intermedia del cerro; Uxama se mantiene en el Castro, centrado inicialmente en las dos cumbre planas que lo forman y se unen en el Noroeste, para extenderse ahora por el estrecho barranco que hacia el Sudeste desemboca en el río Ucero; Numancia es la que menos ampliación sufre, quedando circunscrita a la cumbre del cerro, aunque pasa de tener unas 9 hectáreas a 15. Corresponde a época imperial romana y es la mejor conocida, desarrollando una superficie total de unas 10,7 hectáreas de superficie, de las que 6,48 ha corresponderían a la superficie de casas y 4,52 ha estarían destinadas a calles, lo que proporciona un número aproximado de 648 casas, de 100 $\mathrm{m}^{2}$, que multiplicado por 4 ocupantes, superan en poco los 2500 habitantes; pero la superficie destinada a casas sería aún menor, ya que habría que valorar los espacios de los patios interiores dentro de las manzanas, así como las ocupadas por edificios públicos, actividades artesanales o tiendas, lo que permite pensar en una cifra no muy superior a los 2000 habitantes.

La lengua celtibérica se sigue manteniendo como lo demuestran algunos textos escritos en celtíbero (Fig. 34), aparte de los letreros monetales, los tres epígrafes funerarios de Langa, Trebago y Osma (Hoz 1986: 62-63; Albertos y
Romero 1981: 199-204; García Merino 1983: 356), así como dos téseras de Uxama (Hoz 1986: 66; García Merino y Albertos 1981 y 1985), que se fechan en momentos poco definidos del siglo I a.C.

Estos cambios encontrarán su momento de mayor expresión a partir de las medidas de César, desarrolladas por Augusto, que consolidarán la ordenación del territorio, atendiendo ya claramente a la nueva orientación política $\mathrm{y}$ al incremento de las explotaciones agrarias sistemáticas (villae) en las llanuras cerealistas, fijando claramente los núcleos urbanos que centralizarán el territorio (Fig. 35). El nuevo modelo agrícola romano va a significar una concepción diferente de los usos del suelo, de los procesos de comercialización de la producción agropecuaria $\mathrm{y}$, por tanto, de los hábitos culturales del campesinado; todo esto unido al desarrollo de nuevos focos de producción y comercio más atractivos, provocados por el cambio de orientación económica, llevaría paralelamente a la creación de vacíos y al abandono de antiguos núcleos de población (Miret et al. 1987: 79). A esto contribuirán las vías o red de caminos, que comunicarán más rápidamente el valle del Ebro y la Meseta, como la via XXVII del itinerario de Antonino, a través del Queiles con las ciudades de Augustobriga, Numancia, Uxama, como ejes o puntos esenciales y la vía XXV a través del Jalón, con puntos en Arcobriga y Segontia; a su vez, Termes en el Suroeste será el punto de articulación en sentido Norte-Sur, poniendo en comunicación el valle del Duero (Uxama) con el Alto Tajo (Segontia) y Alto Jalón (Arcobriga).

Otras ciudades son de nueva creación o han perdido las referencias del asentamiento anterior, como Augustobriga, fundación atribuida a Augusto con motivo de las Guerras contra Cántabros y Astures, citada como mansión en la vía romana número XXVII del Itinerario de Antonino, que desde Caesaraugusta (Zaragoza) se dirigía a Asturica (Astorga) (Saavedra 1861) y para la que recientemente se ha podido determinar, como ya se ha indicado, su ubicación en la antigua ciudad celtibérica de Arecoratas (Jimeno et al. 2010). Las zonas de mayor atracción por su producción cerealista, como son el Campo de Gómara y la Tierra de Almazán contarán ahora con sus 
núcleos de control territorial, como Villalba, junto a Almazán (Soria), y Villaseca de Arciel, junto a Gómara (Soria); también en la zona de Quintana Redonda, el yacimiento de Royo Albar-Las Quintanas (Soria) pudo jugar este papel.

No obstante, los estudios hasta ahora se han centrado más en las ciudades de urbanística romana por su mayor monumentalidad y mejor conservación, pero paralelamente a las ciudades con grandes actuaciones edilicias conviven otros núcleos que mantuvieron la urbanística indígena y que fueron adaptándola y cambiándola de acuerdo con la nueva realidad económica y social. Un ejemplo lo proporciona Numancia, que no mostrará ahora una mayor complejidad urbanística, pero sí en las estructuras domésticas, dispuestas en plantas cuadrangulares o trapezoidales, con patio de acceso, vestíbulo y varias estancias, con unos $100 \mathrm{~m}^{2}$, a las que habría que añadir otras dependencias anejas de servicios. Este tipo de arquitectura doméstica, conectada con la tradición de la zona, alternará con las casas de planta y estructura ya decididamente romana, como las viviendas con patios columnados del barrio sur (Fig. 36), que dada su mayor monumentalidad han sido las más difundidas. Se acusa ya una planificación urbanística edilicia que diseña los trazados de las calles y grandes manzanas, delimitadas por un muro perimetral, de mejor factura y regular, mientras que las casas familiares, dentro de la manzana, muestran la actuación privada con rectificaciones y compartimentaciones, acordes con las necesidades familiares, ordenadas en torno a patios, pero donde hay también diferenciados talleres, lugares de almacenamiento, tiendas, establos y basureros.

En una centuria se modificó de forma casi radical la Celtiberia, utilizando la ciudad como instrumento de romanización y centro de control territorial, aplicando esta política en dos fases, una a mediados del siglo I a.C. y otra con el cambio e inicio de era. A partir de Augusto muchas ciudades alcanzaron el rango municipal. Esto conllevó la monumentalización de sus edificios y la difusión y uniformidad de múltiples aspectos de la cultura material. Así, la arquitectura, completada con esculturas y epígrafes, fue un medio altamente eficaz, bien manejado por las élites, para transmitir la ideología de poder.

\section{REFERENCIAS BIBLIOGRÁFICAS}

Albertos, M.L.; Romero, F. (1981): Una estela y otros hallazgos celtibéricos en Trébago (Soria). B.S.A.A., XLVII: 199-208.

Alfaro, E. (2005): Castillejos y Villares. Modelos de poblamiento antiguo en el interior del Sistema Ibérico. Soria Edita, Madrid.

Almagro-Gorbea., M. (1994): Urbanismo de la Hispania "Céltica". Castros y Oppida del centro y occidente de la Península Ibérica. Castros y Oppida en Extremadura (M. Almagro-Gorbea, A. Martín Bravo, eds.), Complutum extra 4, Madrid: 13-75.

Almagro-Gorbea, M. (1996): Ideología y Poder en Tartessos y el mundo ibérico. Discurso de ingreso en la Real Academia de la Historia, Madrid.

Almagro-Gorbea, M. (2001): Aproximaciones a la demografía de la Celtiberia. Entre Celtas e Íberos. Las poblaciones protohistóricas de las Galias e Hispania (L. Berrocal, Ph. Gardes, coords.), Real Academia de la Historia-Casa de Velazquez, Madrid: 45-60.

Almagro-Gorbea, M. (2003): Epigrafia prerromana. Real Academia de la Historia, Madrid.

Almagro-Gorbea, M. (2005): Segobriga (Saelices, Cuenca). Celtíberos. Tras la estela de Numancia (A. Jimeno, ed.), Junta de Castilla y León-Diputación de Soria-Caja Duero, Salamanca: 191-196.

Almagro-Gorbea, M.; Berrocal, L. (1997): Entre iberos y celtas: sobre santuarios comunales urbanos y rituales gentilicios en Hispania. Cuadernos de Prehistoria y Arqueología Castellonense, 18: 567-588.

Almagro-Gorbea, M.; Dávila, A. F. (1995): El área superficial de los oppida en la Hispania "céltica". Complutum, 6: 209-239.

Almagro-Gorbea, M.; Abascal, J. M. (1999): Segóbriga y su conjunto arqueológico. Real Academia de la Historia y Junta de Comunidades de Castilla-La Mancha, Madrid. 
Almagro-Gorbea, M.; Torres, M. (1999): Las fibulas de jinete y de caballo. Aproximación a las élites ecuestres y su expansión en la Hispania céltica. Institución "Fernando El Católico", Zaragoza.

Álvarez-Sanchís, J. (1999): Los Vettones. Bibliotheca Archaeologica Hispana, 1, Real Academia de la Historia, Madrid.

Álvarez-Sanchís, J.; Ruiz Zapatero, G. (2001): Cementerios y asentamientos: bases para una demografía arqueológica de la Meseta en la Edad del Hierro. Entre Celtas e Íberos. Las poblaciones protohistóricas de las Galias e Hispania (L. Berrocal, Ph. Gardes, coords.), Real Academia de la Historia-Casa de Velazquez, Madrid: 61-75.

Arenas, J. (1999): Comercio protohistórico: Líneas de contacto entre Levante y el Sistema Ibérico. Economía. IV simposio sobre los celtíberos (F. Burillo, coord.), Institución Fernando el Católico, Zaragoza: 301-309.

Arenas, J. A. (1999): La Edad del Hierro en el Sistema Ibérico central, España. BAR International Series 780 , Oxford.

ArenAS, J. (2005): El mundo celtibérico y sus relaciones con el mundo ibérico y mediterráneo. Celtíberos. Tras la estela de Numancia (A. Jimeno, ed.), Junta de Castilla y León, Diputación de Soria, Ayuntamiento de Soria, Caja Duero, Salamanca: 395-400.

Arenas, J.; Martínez, J. P. (1999): La explotación de la sal durante la Edad del Hierro en el sistema ibérico. IV Simposio sobre Celtíberos: Economía (F. Burillo, coord.), Institución "Fernando El Católico", Zaragoza.

Arenas, J.; De Bernardo, P. (2001): La estela de Retugenus (K.12.21) y el imperativo celtibérico. Emerita, LXIX2: 307-318.

Argente Oliver, J. L. (1990): Tiermes. Guia del yacimiento y museo. Junta de Castilla y León, Soria

ArLegui, M. A. (1992): El yacimiento celtibérico de "Castilmontán", Somaen (Soria): El sistema defensivo. II Symposium de Arqueología Soriana (Soria 1989), t. I, Soria: 495-513

AsEnsio, J. A. (1995): La ciudad en el mundo prerromano en Aragón. Caesaraugusta, 70, Institución "Fernando El Católico", Zaragoza.

Beltrán, A. (1988): Contrebia Belaisca (Botorrita, Zaragoza). Celtíberos (F. Burillo, J. A. Pérez Casas, M. L. de Sus Jiménez, eds.), Zaragoza: 44-49.

Beltrán, A.; Tovar, A. (1982): Contrebia Belaisca (Botorrita, Zaragoza). I. El bronce con alfabeto ibérico de Botorrita. Monografía Arqueológica, 22, Zaragoza.

Beltrán, M. (1986): Problemas cronológicos de la celtiberia aragonesa. I Symposium sobre los Celtíberos, Daroca: $19-42$.

Beltrán Lloris, F. (1989): Los Celtíberos y su Historia. Los Celtas en el Valle Medio del Ebro (VV.AA., eds.), Zaragoza: 131-154

Beltrán, F.; De Hoz, J.; Untermann, J. (1996): El tercer bronce de Botorrita (Contrebia Belaisca). Zaragoza.

Beltrán Lloris, M. (2005): Contrebia Belaisca (Botorrita, Zaragoza). Celtíberos. Tras la estela de Numancia (A. Jimeno, ed.), Junta de Castilla y León, Diputación y Ayuntamiento de Soria, Caja Duero, Salamanca: 137-144.

Bendala, M.; Fernández, C.; Fuentes, A.; ABAd, I. (1986): Aproximación al urbanismo prerromano y a los fenómenos de transición y de potenciación tras la conquista. Coloquio sobre asentamientos ibéricos ante la romanización, Madrid.

Blanco. J. F. (2005): Relación de los celtíberos con el mundo meseteño. Celtíberos. Tras la estela de Numancia (A. Jimeno, ed.), Junta de Castilla y León, Diputación y Ayuntamiento de Soria, Caja Duero, Salamanca: 401-408.

Borobio, M. J.; Morales, F.; Pascual, A.C. (1992): Primeros resultados de las excavaciones realizadas en Medinaceli. Campañas 1986-1989. Actas del $2^{\circ}$ Symposium de Arqueología Soriana, Colección "Temas Sorianos", núm. 20, Diputación Provincial de Soria, Soria: 769-783.

Burillo, F. (1980): El Valle Medio del Ebro en época ibérica. Contribución a su estudio en los ríos Huerva y Jiloca Medio. Institución Fernando el Católico, Diputación de Zaragoza, Zaragoza.

BuRILlo, F. (1998): Los Celtíberos. Etnías y Estados. Ed. Crítica, Barcelona.

BuRillo, F. (2005): Segeda. La ciudad celtibérica que cambió el calendario. Fundación Segeda, Zaragoza. 
Burillo, F. (2006): La ciudad estado de Segeda I. Segeda y su contexto Histórico entre Catón y Nobilior (195 al 153 a.C.) Homenaje a Antonio Beltrán Martínez (F. Burillo, ed.), Fundación Segeda-Centro de Estudios Celtibéricos, Zaragoza.

Burillo, F. (2007): Los Celtíberos. Etnias y estados. Crítica, Barcelona.

Burillo, F. (2007): Segeda y su contexto histórico. Entre Catón y Nobilior (195 al 153 a.C.), Homenaje a Antonio Beltrán Martínez. Fundación Segeda-Centro de Estudios Celtibéricos, 2, Zaragoza.

Burillo, F.; Sus, M. L. DE (1988): La casa 2 de Herrera. Celtíberos (F. Burillo, J. A. Pérez Casas, M. L. de Sus Jiménez, eds.), Zaragoza: 62-67.

Burillo, F.; Aranda, A.; Pérez, J.; Polo, C. (1995): El poblamiento celtibérico en el valle medio del Ebro. III Simposio sobre los celtíberos. Poblamiento celtibérico (F. Burillo, coord.), Institución Fernando el Católico, Zaragoza: 245-264.

Caballero, C. (2003): La ciudad y la romanización de Celtiberia. Institución Fernando el Católico, Colección Estudios, Zaragoza.

Cerdeño, M. L. (1976): La Necrópolis Celtibérica de Valdenovillos (Guadalajara). Wad-al-Hayara, 3: 5-26.

Cerdeño, M. L.; Sanmartí, E.; García. R. (1999): Las relaciones comerciales de los celtíberos. Economía. IV Simposio sobre los celtíberos (F. Burillo, coord.), Institución Fernando el Católico, Zaragoza: 263-299.

Cerdeño, M. L.; Juez, P. (2002): El castro celtibérico de "El Ceremeño" (Herrería, Guadalajara). Monografías Arqueológicas del SAET, 8, Teruel.

Cerdeño, M. L.; SAgardoy, T.; ChordÁ, M.; Gamo, E. (2008): Fortificaciones celtibéricas frente a Roma: el oppidum de Los Rodiles (Cubillejo de la Sierra, Guadalajara). Complutum, 19: 173-189.

Checa, A.; Jimeno, A.; Juan, J.; Benito, J. P.; Sanz, A. (1999): Molienda y economía doméstica en Numancia. Economía. IV Simposio sobre Celtíberos (F. Burillo, ed.), Institución Fernando el Católico, Zaragoza: 63-67.

CuBERo, C. (1999): Agricultura y recolección en el área celtibérica a partir de datos paleocarpológicos. Economía. IV Simposio sobre Celtíberos (F. Burillo, coord.), Institución Fernando el Católico, Zaragoza: 47-61.

Díaz, M.A.; Medrano, M. (1987): Objetos de bronce procedentes de las áreas de cronología romano-republicana de la ciudad de Contrebia Belaisca (Botorrita, Zaragoza). XVIII Congreso Nacional de Arqueología, Zaragoza.

Domínguez Arranz, A. (1988): La moneda celtibérica. Celtíberos (F. Burillo, J. A. Pérez Casas, M. L. de Sus Jiménez, eds.), Zaragoza: 155-169.

Domínguez Arranz, A. (1988): Nuevos hallazgos de bronces con leyenda celtibérica Arekorata. Bolskan, 5: 249-262.

Domínguez Monedero, A. (2005): Organización urbana e incidencia romana. Celtíberos. Tras la estela de Numancia (A. Jimeno, ed.), Junta de Castilla y León, Diputación y Ayuntamiento de Soria, Salamanca: 285-292.

D'ors, A. (1951): Un nuevo dato para la Historia de la llamada Termancia. Estudios dedicados a Menéndez Pidal, t II: 567-582.

FatÁs, G. (1980): Contrebia Belaisca II. Tabula Contrebiensis. Zaragoza.

FAтÁs, G. (1985): Una tésera cortonense. Symbolae Lvdivico Mitxelena Setvagenario Oblatae, Vitoria: 425-431.

Faro, J. A.; Unzu, M. (2006): La necrópolis de la Edad del Hierro de El Castillo (Castejón, Navarra). Primeras valoraciones: campañas 2000-2002. Complutum, 17: 145-166.

Galán, E. (2005): Artistas y artesanos. Celtíberos. Tras la estela de Numancia (A. Jimeno, ed.), Junta de Castilla y León, Diputación y Ayuntamiento de Soria, Caja Duero, Salamanca: 329-336.

Galantay, E. (1977): Nuevas ciudades: de la Antigüedad a nuestros dias. Ed. Gustavo Gili, Barcelona.

García Bellido, M. P. (1994): Sobre la localización de Segobrix y las monedas del yacimiento de Clunia. Archivo Español de Arqueología, 67: 245-259.

García Gelabert, M. P. (1990-1): Marco sociopolítico de Celtiberia. Lucentum, IX-X: 103-110.

García Merino, C. (1975): Población y poblamiento en la Hispania Romana. El Conventus Cluniensis, Valladolid. 
García Merino, C. (1989): Uxama Argaela: El yacimiento y su historia. Diez Años de Arqueología Soriana (1978-1988), Museo Numantino, Soria.

García Merino, C. (2001): Historia de Uxama. Historia del Burgo de Osma, Soria.

García Merino, C. (2005): Uxama Argaela. Celtíberos. Tras la estela de Numancia (A. Jimeno, ed.), Junta de Castilla y León, Diputación y Ayuntamiento de Soria, Caja Duero, Salamanca: 177-182.

García Quintela, M. V. (2002): La organización sociopolitica de los populi del Nordeste de la Península Ibérica. Un estudio de antropología política histórica comparada. TAPA (Traballos de Aqueoloxìa e Patrimonio), 28.

García Riaza, E. (2006): La expansión romana en la celtiberia. Segeda y su contexto histórico entre Catón y Nobilior (195 al 153 a.C.). Homenaje a Antonio Beltrán Martínez, (F. Burillo, coord.), Fundación Segeda-Centro de Estudios Celtibéricos, Zaragoza: 81-94.

Gómez-Pantoja, J.; Morales, F. (2002): Sertorio en Numancia: una nota sobre los campamentos de la Gran Atalaya. Arqueología militar romana en Hispania (A. Morillo, ed.), Madrid: 303-310.

GonzÁlez Ruibal, A. (2003): La experiencia del otro. Una introducción a la Etnoarqueología. Akal Arqueología, Madrid.

González Simancas, M. (1926): Las fortificaciones de Numancia. Excavaciones practicadas para su estudio. Junta Superior de Excavaciones y Antigüedades, 74, Madrid.

HeRAs, E. (2000): Aproximación a la evolución del poblamiento en el suroeste de la provincia de Soria durante la Edad del Hierro y la etapa Alto Imperial. Soria Arqueológica, 2, Diputación Provincia del Soria, Soria: 205-238

Hernández Vera, J. A. (2007): Contrebia Leucade, guía arqueológica. Gobierno de La Rioja, La Rioja.

Hoz, DE, J. (1986): La epigrafía celtibérica. Actas de la reunión sobre Epigrafia Hispánica de época romana republicana, Zaragoza: 163-179.

Jimeno, A. (1980): Epigrafía romana de la provincia de Soria. Temas Sorianos, 2, Diputación Provincial de Soria, Soria.

Jimeno, A. (2000): El origen del urbanismo en el Alto Duero. Soria Arqueológica, 2, Soria: 239-262.

Jimeno, A. (2005): Un paisaje celtibérico: entre rebaños y campos. Soria en el Paisaje I, Soria Edita, La Rioja.

Jimeno, A. (2006): Conquest and Romanization in Celtiberia Ulterior: Numantia as Paradigm. Early Roman Towns in Hispania Tarraconensis (L. Abad; S. Keay; S. Ramallo Asensio, eds.), Journal of Roman Archaeology, Supplementary Series, 62, Portsmouth, U.S.A.: 172-183.

Jimeno, A. (2009): Espacio doméstico y sociedad en la Celtiberia Ulterior. Léspai domèstic i l'organizació de la societat a la protohistòria de la Meditarrània occidental (Ier millenni a.C.) (C. Belarte, ed.), Arqueomediterrània, II, Actas de la IV Reunió Internacional d'Arqueologia de Calafell: 189-211.

Jimeno, A.; Arlegui, M.A. (1995): El poblamiento en el Alto Duero. III Simposio sobre los celtíberos (F. Burillo, coord.), Zaragoza: 93-126.

Jimeno, A.; Tabernero, C. (1996): Origen de Numancia y su evolución urbana. Homenaje al Profesor Fernández-Miranda, Complutum (extra), 6-1: 415-432.

Jimeno, A.; Fernández, J. J.; Revilla, M. L. (1990): Numancia: Guía del Yacimiento. Asociación de Amigos del Museo Numantino, Soria.

Jimeno, A.; SAnz, A.; Benito, J.P. (2000): Numancia: reconstruir para entender. Revista de Arqueología, 175.

Jimeno, A.; SANZ, A.; Benito, J. P. (2001): La reconstrucción arquitectónica, alternativa para la comprensión de Numancia. Arqueomediterránea, 6: 117-132.

Jimeno, A.; De La Torre, J. I.; Berzosa, R.; Martínez, J. P. (2004): La necrópolis celtibérica de Numancia. Arqueología en Castilla y León, Memorias, 12, Junta de Castilla y León, Salamanca.

Jimeno, A.; De La Torre, J. I. (2005): Numancia, Símbolo e Historia. Akal Arqueología, 6, Madrid.

Jimeno, A.; SAnz, A.; De Bernardo, P.; TABernero; C.; Benito (2010): Nueva tésera hallada en Muro (Soria) y la posible ubicación de "AreKoraTa". VI Simposio sobre Celtíberos. Ritos y Mitos (F. Burillo, ed.), Fundación Ségeda-Centro de Estudios Segedenses, Zaragoza: 291-297.

KnApP, R. C. (1979): Celtiberian conflict with Rome: policy and coinage. Actas del II Coloquio sobre lenguas y culturas prerromanas de la Península Ibérica (Tubingen, 1976), Salamanca: 465-472. 
Lostal Pros, J. (1980): Arqueología del Aragón Romano. Institución "Fernando El Católico", Diputación Provincial, Zaragoza.

Lenerz de Wilde, M. (1986): Art celtique et armes iberiques. Actes du Ville Colloque sur les Ages du Fer, 1984. Aquitania (Suppl.): 273-280.

Lorrio, A. (1997): Los Celtíberos. Complutum Extra. Universidad de Alicante, Universidad Complutense de Madrid.

Lorrio, A.; SÁnchez, M. D. (2009): La necrópolis celtibérica de Arcobriga, Monreal de Ariza. Caesaraugusta, 80, Zaragoza.

Mangas, J. (1983): Hispania romana. Historia de España, Vol. I (M. Tuñón de Lara, dir.), Ed. Labor, Barcelona.

Marco Simón, F. (1999): El Bronce de Botorrita (cara B), como exposición de sinecismo político. Actas del VII coloquio sobre lenguas y culturas paleohispánicas (F. Villar, R. F. Beltrán, eds.), Salamanca: 269-280.

Martín Valls, R., Esparza, A. (1992): Génesis y evolución de la Cultura Celtibérica. Paleoetnología de la Península Ibérica (M. Almagro-Gorbea, G. Ruiz Zapatero, eds.), Complutum, 2-3: 259-279.

Martínez, S.; Mangas, J. (2005): Tiermes celtibérica. Celtíberos. Tras la estela de Numancia (A. Jimeno, ed.), Junta de Castilla y León, Diputación y Ayuntamiento de Soria, Caja Duero, Salamanca: 169-175.

Medrano, M. (1987): Ponderales ibéricos procedentes de la ciudad celtibérica de Bílbilis (Valdeherrera, Calatayud). I Simposium sobre los celtíberos, Zaragoza: 149-161.

MÉLIDA, J. R. (1926): Ocilis (Medinaceli). Memoria de las excavaciones practicadas en 1924-25. Memoria de la Junta Superior de Excavaciones y Antigüedades, núm. 82.

Olmos, R. (1986): Notas conjeturales de iconografía celtibérica. Tres vasos de cerámica polícroma de Numancia. Numancia, II: 215.

Miret, M.; Sanmartí, J.; Santacana, J. (1987): La evolución y el cambio de modelo de poblamiento ibérico ante la romanización. Los asentamientos ibéricos ante la romanización, Madrid: 79-88.

Ortega, J. (1999): Al margen de la "identidad cultural": Historia social y economía de las comunidades campesinas celtibéricas. Economía. IV Simposio sobre los celtíberos (F. Burillo, coord.), Institución Fernando el Católico, Zaragoza: 417-452.

Ortega, J. (2006): Socios et consanguineos: dos reflexiones sobre la ciudad, el parentesco y la etnia en la Celtiberia. Segeda y su contexto histórico entre Catón y Nobilior (195 al 153 a.C.). Homenaje a Antonio Beltrán Martínez (F. Burillo, coord.), Fundación Segeda-Centro de Estudios Celtibéricos, Zaragoza: 169-175.

Otero, P. (1993): Consideraciones sobre la presencia de acuñaciones celtibéricas en zonas mineras de la Hispania Ulterior. XI Congrès International de Numismatique, II, Louvain-la-Neuve: 49-58.

Otero, P. (entrevista de Nuria Omeñaca) (2007): Las huellas de Arecorata. Las monedas hablan de una ciudad perdida en el pasado soriano. Heraldo de Soria (suplemento "De domingo", 25 de Marzo), Soria

Pascual, A. C. (1991): Carta Arqueológica de Soria. Zona Centro. Diputación Provincial de Soria, Soria.

Palol, P. (1969): Guía de las excavaciones y de la ciudad romana. Diputación Provincial de Burgos, Burgos.

Pérez Vilatela, L. (1990): Cuestiones de Historia Antigua y toponimia turiasonense: la batalla del Moncayo (179 a. C.). Turiaso X, 1, Tarazona.

PINA, F. (1997): Las Comisiones Senatoriales para la reorganización de Hispania (App. Iber., 99-100). Dialogues d'Histoire Ancienne, vol. 23, $\mathrm{n}^{\circ}$ 23-2: 83-104.

PINA, F. (2006): Imperialismo y estrategia militar en la conquista de Hispania Citerior (218-153). Segeda y su contexto histórico entre Catón y Nobilior (195 al 153 a.C.). Homenaje a Antonio Beltrán Martínez (F. Burillo, coord.), Fundación Segeda-Centro de Estudios Celtibéricos, Zaragoza: 71-80.

QuesADA, F. (1997): ¿Jinetes o caballeros? En torno al empleo del caballo en la Edad del Hierro. La Guerra en la Antigüedad. Catálogo de la Exposición, Madrid: 185-194.

QuesaDA, F. (2006): Los celtíberos y la guerra: tácticas, cuerpos, efectivos y bajas. Un análisis a partir de la campaña del 153. Segeda y su contexto histórico entre Catón y Nobilior (195 al 153 a.C.). Homenaje a Antonio Beltrán Martínez (F. Burillo, coord.), Fundación Segeda-Centro de Estudios Celtibéricos, Zaragoza: 149-167.

RABAL, N. (1889): Soria, España sus monumentos y artes, su naturaleza e Historia. Ed. Daniel Cortezo, Barcelona. 
Renfrew, C. (1982): The explanation revisited. Theory and Explanation in Archaeology (Conference Proceeding) (E C. Renfrew, M. Rowland, B. Segraves, eds.), Academic Press, New York: 5-23.

Romero Carnicero, F. (1976): Las cerámicas polícromas de Numancia. Centro de Estudios Sorianos, Valladolid.

Romero Carnicero, F. (1991): Los Castros de la Edad del Hierro en el Norte de la Provincia de Soria. Studia Archaeologica, núm. 80, Universidad de Valladolid, Valladolid.

Romero Carnicero, M. V. (1992): La romanización en la provincia de Soria. Panorama y perspectivas. Actas del $2^{\circ}$ Symposium de Arqueología Soriana, Colección “Temas Sorianos”, núm. 20, Diputación Provincial de Soria, Soria.

Romero Carnicero, F. (1999): El Vaso de los Guerreros de Numancia. Aproximación a su lectura iconográfica. Homenaje a José Luis Argente, Revista de Soria, 25: 51-65.

Romero Carnicero, M. V. (2005): Cambios posteriores y romanización. Celtíberos. Tras la estela de Numancia (A. Jimeno, ed.), Junta de Castilla y León, Diputación de Soria y Ayuntamiento de Soria, Caja Duero, Salamanca: 435-444.

Ruiz-Gálvez, M. L. (1992): La novia vendida: Agricultura, herencia y orfebrería en la Protohistoria de la Península Ibérica. SPAL, 1: 219-251.

Ruiz-Gálvez, M. L. (2005): Comercio e intercambio entre los celtíberos. Celtíberos. Tras la estela de Numancia (A. Jimeno, ed.), Junta de Castilla y León, Diputación de Soria, Ayuntamiento de Soria, Caja Duero, Salamanca: $375-380$.

Ruiz Zapatero, G. (1984): Comercio protocolonial y orígenes de la iberización. Kalathos, 3-4.

SaAvedra, E. (1861): Descripción de la Via Romana entre Uxama y Augustobríga. Real Academia de la Historia, Madrid.

SaCristán, J.D. (1994): Clunia. Leyenda y Arqueología de las Ciudades Prerromanas de la Península Ibérica, II. Museo Arqueológico Nacional, Madrid.

SACRISTÁn, J. D. (2005): Clunia. El confín de la Celtiberia. Celtíberos. Tras la estela de Numancia (A. Jimeno, ed.), Junta de Castilla y León, Diputación de Soria-Ayuntamiento de Soria, Caja Duero, Salamanca: 183-190.

Salinas de Frías, M. (1988): Conquista y Romanización de la Celtiberia. Universidad de Salamanca-Museo Numantino, Salamanca

SÁnchez Moreno, E. (1993): Orígenes y desarrollo del urbanismo en la Protohistoria europea. II Edad del Hierro. Revista de Arqueología, 141: 10-17.

Sancho, M.C. (1985): Guía de Medinaceli, Soria.

Schulten, A. (1945): Historia de Numancia. Ed. Barna, Barcelona.

Tabernero, C.; Heras, E.; Benito, J. P.; Sanz, A. (2005): Segontia Lanka. Celtíberos. Tras la estela de Numancia (A. Jimeno, ed.), Junta de Castilla y León, Ayuntamiento de Soria-Caja Duero, Salamanca: 197-204.

Taracena, B. (1924-1925): Excavaciones en diversos lugares de la provincia de Soria. Memorias de la Junta Superior de Excavaciones y Antigüedades, 75.

Taracena, B. (1926): Noticias de un despoblado junto a Cervera del río Alhama. Archivo Español de Arte y Arqueología, II: 137-142.

Taracena, B. (1929): Excavaciones en la provincia de Soria y Logroño, Memorias de la Junta Superior de Excavaciones y Antigüedades, núm 103, Madrid.

TARACEna, B. (1929): Excavaciones en la provincia de Soria, Memorias de la Junta Superior de Excavaciones y Antigüedades, núm 109, Madrid.

Taracena, B. (1931-32): La ceramica romana de Clunia. Archivo de Prehistoria Madrileña, II-III: 85.

Taracena, B. (1941): Carta Arqueológica de España. Soria. Instituto Diego Velázquez, C.S.I.C., Madrid.

Taracena, B. (1954): Los Celtíberos. Historia de España (R. Menéndez Pidal, dir.), t. I, vol. III, EspasaCalpe, Madrid: 195-299.

Tibiletti, GT.F. (1978): La romanizzazione della valle padana. Storie Locali dell'Italia Romana, Pavía.

Traggia, J. (1792): Aparato a la Historia Eclesiástica de Aragón, t. I, Madrid: 157-167.

Vicente, J. (1991): La Caridad (Caminreal, Teruel). La Casa Urbana Hispanorromana, Zaragoza: 81-129.

Wattenberg, F. (1963): Las cerámicas indígenas de Numancia. Bibliotheca Praehistorica Hispana, IV, Madrid. 